\title{
POLICY, INSTITUTIONAL FACTORS AND EARNINGS MOBILITY
}

\author{
Denisa Maria Sologon \\ Cathal O'Donoghue
}

November 2009

Working Papers

MGSoG / 2009 / 021

\section{Maastricht Graduate School of Governance (MGSoG)}




\title{
Maastricht Graduate School of Governance
}

The 'watch dog' role of the media, the impact of migration processes, health care access for children in developing countries, mitigation of the effects of Global Warming are typical examples of governance issues - issues to be tackled at the base; issues to be solved by creating and implementing effective policy.

The Maastricht Graduate School of Governance, Maastricht University, prepares students to pave the road for innovative policy developments in Europe and the world today.

Our master's and $\mathrm{PhD}$ programmes train you in analysing, monitoring and evaluating public policy in order to strengthen democratic governance in domestic and international organisations. The School carefully crafts its training activities to give national and international organisations, scholars and professionals the tools needed to harness the strengths of changing organisations and solve today's challenges, and more importantly, the ones of tomorrow.

\author{
Authors \\ Denisa Maria Sologon, PhD fellow \\ Maastricht Graduate School of Governance \\ Maastricht University \\ Email: denisa.sologon@ maastrichtuniversity.n \\ Harvard Kennedy School of Government \\ Harvard University
}

\section{Cathal O'Donoghue}

Teagasc Rural Economy Research Centre

NUI Galway; IZA and ULB

Email: Cathal.ODonoghue@teagasc.ie

\section{Mailing address}

Universiteit Maastricht

Maastricht Graduate School of Governance

P.O. Box 616

6200 MD Maastricht

The Netherlands

\section{Visiting address}

Kapoenstraat 2, $6211 \mathrm{KW}$ Maastricht

Phone: +31 433884650

Fax: +31433884864

Email: info-governance@ maastrichtuniversity.n 


\section{ABSTRACT \\ POLICY, INSTITUTIONAL FACTORS AND EARNINGS MOBILITY}

This paper uses ECHP and OECD data for 14 EU countries to explore the role of labour market factors in explaining cross-national differences in the dynamic structure of earnings: in permanent inequality, transitory inequality and earnings mobility. Based on ECHP, minimum distance estimator is used to decompose earnings inequality into the permanent and transitory components and compute earnings mobility. The predicted components together with the institutional OECD data are used in a non-linear least squares setting to estimate the relationship between permanent inequality, transitory inequality and earnings mobility, and labour market policy and institutional factors. The results revealed a highly complex framework, where institutions interact significantly not only with each other and with the overall institutional setting, but also with the macroeconomic shocks in shaping the pattern of the three labour market outcomes.

JEL Classification: C23, D31, J31, J60, J50, J08

Keywords: panel data, wage distribution, inequality, mobility, labour market institutions; labour market policies

Corresponding Author:

Denisa Maria Sologon

Maastricht Graduate School of Governance

Kapoenstraat 2, KW6211 Maastricht

The Netherlands

Email: denisa.sologon@ maastrichtuniversity.n 


\section{INTRODUCTION}

The rise in earnings inequality experienced by many developed countries during the 1980s and 1990s triggered a strong debate with respect to the driving factors behind individual earnings dynamics and the implications of this increase. The empirical literature has covered extensively the driving factors behind the increase in cross-sectional earnings inequality. Factors like economic growth ("Kuznetz hypothesis"); "the shift in demand away from unskilled labour in favour of skilled workers" (Atkinson 1996) under the impact of trade liberalization, skill-biased technological change and organizational change; the role of changes in the labour market institutions, such as unionization and centralized bargaining, macroeconomic volatility, are among the main possible drivers of income inequality as identified by the empirical literature. (Freeman and Katz, 1994; 1995; Fortin and Lemieux, 1997; Gottschalk and Smeeding, 1997; Katz and Autor, 1999; Aghion and Williamson, 2001)

Notwithstanding this, the empirical literature has neglected so far the driving factors behind the two components of earnings inequality: permanent and transitory inequality. Even less attention was given to the driving factors behind earnings mobility, which, as stated by Milton Friedman (1962), represents a very important aspect for understanding inequality. All these labour market outcomes are highly important given that the interplay between them determines the final earnings inequality outcome, both in an annual and lifetime perspective.

In this line of thought, this paper explores the role of labour market policy and institutional factors in explaining cross-national differences in the evolution of permanent inequality, transitory inequality and earnings mobility across $14 \mathrm{EU}$ countries. So far, at the EU level, no study attempted to analyse and to understand the driving factors behind the three labour market outcomes in a comparative manner.

Understanding the driving forces behind these labour market outcomes is vitally important from a welfare perspective, particularly given the large variation in the evolution of cross-sectional wage inequality across Europe over the period 1994-2001. Did the increase in cross-sectional wage inequality observed in some countries result from greater transitory fluctuations in earnings and individuals facing a higher degree of earnings mobility? Or is this rise reflecting increasing permanent differences between individuals with mobility remaining constant or even falling?

What about countries that recorded a decrease in cross-sectional earnings inequalities, what 
lessons can we learn from them? What are the possible labour market policy and institutional factors that can explain these trends in permanent and transitory differentials, and earnings mobility?

These questions have a twofold importance. One the one hand, understanding the contributions of the changes in permanent and transitory components of earnings variation to the changes in cross-sectional earnings inequality is very useful in the evaluation of alternative hypotheses for wage structure changes and for determining the potential welfare consequences of rising inequality. (Katz and Autor 1999)

On the other hand, understanding the driving factors behind the changes in permanent and transitory inequality and earnings mobility is very useful for the design of policies and labour market institutions. Earnings mobility is perceived in the literature as a way out of poverty. In the absence of mobility the same individuals remain stuck at the bottom of the distribution, hence annual earnings differentials are transformed into lifetime earnings differentials. Understanding the factors that enhance earnings mobility, represents a step forward towards designing policies and institutions that enable low-wage workers to escape low-wage jobs and improve their position in the distribution of lifetime earnings.

These questions are highly relevant in the context of the changes that took place in the EU labour market policy framework under the incidence of the 1994 OECD Jobs Strategy and the 2000 Lisbon Agenda, which recommended policies to increase wage flexibility, lower non-wage labour costs and allow relative wages to better reflect individual differences in productivity and local labour market conditions. The turnaround in the institutional and policy framework occurred more or less after 1995. (OECD, 2004; Dew-Becker and Gordon, 2008). Before 1995, Europe could have been described as making labour more expensive, accompanied by a decline in employment and an increase in productivity. Starting at different dates for different policies, Europe began the process of shifting toward making labour less expensive, accompanied by higher employment per capita but lower average productivity per hour. (Dew-Becker and Gordon 2008) Moreover, all OECD countries moved towards greater decentralization, which could result in greater inter-firm wage differentials. These trends appear to have worsened the apparent trade-off between a strong employment performance and a more equal distribution of 
earnings, consistent with relative labour demand having shifted towards high-skilled workers. OECD (2004)

As pointed out by Dew-Becker and Gordon (2008) and OECD (2004), the most notable change after 1995 in Europe has been increased country heterogeneity. We will investigate how the heterogeneity in main labour market policy and institutional factors translates itself in the level and components of cross-sectional earnings inequality and earnings mobility.

Using ECHP we apply equally weighted minimum distance methods to estimate the covariance structure of earnings by four birth cohorts for each country, decompose earnings into a permanent and a transitory component and compute earnings mobility. The predicted components - permanent variance, transitory variance and earnings mobility -, together with OECD data on institutional factors, are used to estimate the relationship between these components and labour market policy and institutional factors. The relationship between the labour market policy and institutional factors and the three labour market outcomes is estimated using non-linear least squares.

The structure of this paper is as follows. Section two introduces the literature review, the theoretical background for wage differentials and the theoretical link between labour market factors and the three labour market outcomes. Section three provides a description of the ECHP and OECD data. Section four introduces the econometric specifications and estimation methods for the covariance structure of earnings and for the link between institutional and policy factors and labour market outcomes. Section five describes the dynamic structure of individual log earnings for $14 \mathrm{EU}$ countries and the evolution of the labour market institutions and policies. Section six fits the error components models to the covariance structure for each country, decomposing the change in inequality into that accounted for by the change in the permanent and transitory components. Section seven presents the results on the link between policies and outcomes. Lastly, section eight offers some conclusions. 


\section{THEORETICAL MODEL OF THE DETERMINANTS OF WAGE DIFFERENTIALS}

\subsection{Literature Review}

The existing literature on earnings dynamics is predominantly based on US data. (Atkinson, Bourguignon et al. (1992) provide a comprehensive survey of the literature on earnings dynamics until 1992. The most representative contributions using US or Canadian data were brought by Lillard and Willis (1978), Lillard and Weiss (1979), MaCurdy (1982), Abowd and Card (1989)), Moffitt and Gottschalk (1995, 1998, 2002, 2008), Baker (1997), Baker and Solon (2003). For Europe, the most representative papers are Dickens (2000), Ramos (2003), Kalwij and Alessie (2003), Cappellari (2003), Gustavson (2004).

Finally, Sologon and O'Donoghue (2009a, 2009c) used ECHP for 14 EU countries to explore the dynamic structure of individual earnings and the extent to which changes in cross-sectional earnings inequality reflect transitory or permanent components of individual lifecycle earnings variation. Their main findings are used further in this paper.

The main limitation of the existing studies on earnings dynamics is that they do not explain the main labour market policy and institutional driving factors behind the evolution of the two inequality component and earnings mobility. Our paper attempts to fill part of this gap.

\subsection{Determinants of earnings inequality}

As pointed out by Katz and Autor (1999), the existing literature contains many explanations for the rise in earnings inequality experienced by many developed countries during the 1980s and 1990s. The theory regarding the determinants of wage differentials goes back to Adam Smith, who provided a comprehensive discussion in his capital work, The Wealth of Nations. It was emphasized that wage differentials are determined by competitive factors relating to the workplace (e.g. cost of training), by innate abilities and by labour market institutional factors, which regulated wages, restricted wages and labour mobility. The tension between the demand and supply factors and the institutional factors affecting wage structures that emerged from Adam Smith's analysis has remained until today one of the key themes of research on the wage structure. Following Freeman and Katz (1994), this supply-demand-institutions (SDI) explanation for the changes in the wage structure has three parts. 
The first part assumes that different demographic and skill groups are imperfect substitutes in production, which implies that shifts in the demand and supply for labour skills can alter wage and employment outcomes. Potential important sources of shifts in the relative demand among skill groups include skill-biased technological change and a complementary increase in the prices of other inputs, and forces of globalization (trade and outsourcing). Sources of relative supply include cohort size variation, changes in access to education, immigration. Supply and demand factors are expected to have their largest effect on young workers as opposed to experienced workers with substantial work tenure. (Freeman, 1976)

However, since most advanced countries operate in the same world markets, with similar technology, industry and occupation mixes, demand and supply factors cannot by themselves explain all the differing changes in inequality among these countries. To fully understand the differences in labour market outcomes across advanced countries something else is needed: the institutional framework.(Freeman and Katz 1994)

The second part states that the shock in the demand and supply may have different effects on wages and employment, depending on different wage-setting mechanisms and other labour market institutional factors. The stronger the wage-setting mechanism is, meaning the higher trade union density, the higher the union coverage and the higher the centralisation/co-ordination of wage bargaining, the less impact these shocks have on wages. As argued by OECD (2004), there is a strong evidence that unions reduce wage inequality and that this compression effect is stronger in countries where union membership and bargaining coverage are high, and bargaining is centralised and/or co-ordinated (Aidt and Tzannatos, 2002; Blau and Kahn, 1999, 2002; OECD, 1997a). National labour markets characterized by decentralized wage bargaining experience also a higher skill premia and a higher responsiveness of wages to local conditions, therefore a higher wage inequality.

Thirdly, institutional changes, such as changes in the degree of unionization, the degree of centralization/co-ordination of collective bargaining, or product market regulation can have an impact on the wage structures.

Katz and Autor (1999) used the SDI model to look at cross-country differences in wage structure changes. The shift in the demand for more skilled workers did not result in a sharp increase in wage dispersion for all OECD countries. The differences in the growth of skills supply appear to 
be an important factor in explaining cross-country differences. The same holds for labour market institutions. Countries, where unions, wage bargaining structure play a larger role in the determination of wages recorded smaller increases in inequality. The key issue in the interplay between demand, supply and institutions, however, is the erroneous assumption that institutional change is exogenous. The reality is that institutions are influenced by labour market forces. As argued by Freeman and Gibbons (1995), shifts in supply and demand that raise relative wage differentials are expected to reduce the strength of the centralized collective bargaining and lower union influence on the wage setting mechanism.

\subsection{Permanent and transitory components of earnings inequality}

Following the terminology introduced by Friedman and Kuznets (1954), individual earnings are composed from a permanent and a transitory component. The permanent component of earnings reflects personal characteristics, education, training and other systematic elements. The transitory component captures both individual random factors (e.g. illness and accident) and random changes in the market conditions in a particular period and is expected to average out over time, with no influence on permanent earnings. In general terms, these are factors which are random to the individual perception. Hence, it is logical to require independence between the permanent component and the transitory component. (Weizsacker, 1993) Following the structure of individual earnings and the independence assumption between the two components, overall inequality at any point in time is composed from inequality in the permanent component of earnings and inequality in the transitory component.

One approach for explaining changes in wage differential is to decompose overall wage inequality into the two components. The evolution of the overall earnings inequality is determined by the cumulative changes in the two inequality components. As the factors from the SDI model influence overall inequality, implicitly they influence its two components. The intriguing question that arises is which factors influence which component and to what extent. Our focus in this paper is mainly on labour market policy and institutional factors.

This section tries to establish a theoretical link between the changes in the two inequality components and earnings mobility, and labour market policy and institutional factors. First we introduce alternative specifications for decomposing inequality. Second we introduce the concept of earnings mobility and its link with permanent and transitory inequality. Finally we present the 
theoretical link between institutions and the three labour marker outcomes - permanent inequality, transitory inequality and earnings mobility.

\subsubsection{Alternative model specifications for the permanent and transitory components}

Based on Sologon and O'Donoghue (Sologon and O'Donoghue, 2009b, 2009a, 2009c), we summarize several models of earnings dynamics that have been dominating the literature on permanent and transitory earnings inequality over the past 30 years. For a full review, please refer to Sologon and O'Donoghue (Sologon and O'Donoghue, 2009b, 2009a, 2009c). We begin with the simplest specification, which provides a very intuitive insight into the decomposition of earnings into their permanent and transitory components. Based on this specification earnings are being decomposed as follows:

$$
Y_{i t}=\mu_{i}+v_{i t}, \quad \mu_{i} \sim \operatorname{iid}\left(0, \sigma_{\mu}^{2}\right), \quad v_{i t} \sim \operatorname{iid}\left(0, \sigma_{v}^{2}\right), \quad t=1, \ldots, T_{i}, \quad i=1, \ldots, N
$$

where $\mu_{i}$ represents the permanent time-invariant individual specific component and $v_{i t}$ represents the transitory component, which is independent distributed both over individuals and time. This model imposes very rigid restrictions on the covariance structure of earnings:

$$
\operatorname{Cov}\left(Y_{i t}, Y_{i s}\right)= \begin{cases}\sigma_{\mu}^{2}+\sigma_{v}^{2}, & t=s \\ \sigma_{\mu}^{2}, & t \neq s\end{cases}
$$

Because $\mu_{i}$ is assumed to incorporate the effect of lifetime persistent individual specific characteristics such as ability, the variance of the permanent component $\sigma_{\mu}^{2}$ represents the persistent dispersion of earnings or the inequality in the permanent component of earnings. The transitory shocks are captured by the transitory variance $\sigma_{v}^{2}$ and are assumed to persist only one year.

This model facilitates the understanding of the inequality decomposition into its permanent and transitory components. The variance of earnings at a certain point in time, as a measure of earnings dispersion, is composed both from a permanent and a transitory dispersion $\left(\sigma_{\mu}^{2}+\sigma_{v}^{2}\right)$. The covariances, on the other hand, are determined solely by the permanent component $\left(\sigma_{\mu}^{2}\right)$. Therefore, the assessment of the relative importance of the two components in the overall 
earnings dispersion is straightforward: the ratio $\sigma_{\mu}^{2} / \sigma_{y}^{2}$ captures the relative importance of the permanent component, whereas the ratio $\sigma_{v}^{2} / \sigma_{y}^{2}$ captures the relative importance of the transitory component.

Notwithstanding its attractive features, the empirical evidence rejected the rigid restrictions imposed by model (1). One of the main drawbacks of model (1) is that it does not allow for changes in earnings inequality over time. Other studies (Katz, 1994; Moffitt and Gottschalk, 1995) took the model complexity further by allowing the covariance structure of earnings to vary over time. To account for these time effects, these models considered also time specific loading factors or shifters on both components, which allow the parameters of the process to change with calendar time.

$Y_{i t}=\lambda_{1 t} \mu_{i t}+\lambda_{2 t} v_{i t}$

$\lambda_{k t}, k=1,2$ are time-varying factor loadings on the permanent and transitory components of earnings. The variance of $Y_{i t}$ implied by this model takes the form:

$\operatorname{Var}\left(Y_{i t}\right)=\lambda_{1 t}^{2} \sigma_{\mu}^{2}+\lambda_{2 t}^{2} \sigma_{v}^{2}$

An increase in either time loading factors generates an increase in the cross-sectional earnings inequality. The nature of the change in inequality depends on which of the loading factors changes. On the one hand, a persistent rise in $\lambda_{1 t}$ increases the permanent or long-run inequality (inequality in earnings measured over a long period of time, such as lifetime earnings). As $\lambda_{1 t}$ can be interpreted as time-varying return to skills or skill price, its increase suggests that the relative labour market advantage of high skill workers is enhanced. In this situation, the autocovariances grow in greater proportion that than the variance, causing the autocorrelation to increase. As a consequence, the increase in overall cross-sectional inequality is accompanied by a decrease in mobility. On the other hand, an increase in $\lambda_{2 t}$ without a change in $\lambda_{1 t}$ increases cross-sectional earnings inequality by increasing the transitory inequality, but without any impact on long-run or permanent inequality. In this situation the rise in the variances is not accompanied by a rise in the autocovariances, hence autocorrelations decrease and the increase in the overall inequality is accompanied by an increase in mobility. (Baker and Solon, 2003) As pointed out by Katz and Autor (1999), $\lambda_{1 t}$ maintains the rank of the individuals in the earnings distribution, but 
causes a persistent increase in the spread of the distribution and an increase in $\lambda_{2 t}$ changes the rank of the individual in the short-run. In other words an increase in the time parameters associated with the permanent component of earnings indicates a growing earnings inequality with no impact on the relative position of individuals in the distribution of permanent earnings, whereas an increase in the transitory time parameters indicates an increase in earnings mobility.

Although model (2) incorporates changes over time in the permanent and temporary components of earnings inequality, it disregards other important features of earnings dynamics. Firstly, it disregards the cohort effects. As argued by Katz and Autor (1999), the increased wage inequality may arise from increased dispersion of unobserved labour quality within recent entry cohorts, resulting from unequal school quality. Some studies brought evidence against the hypothesis that the return to education is the same for different cohorts. These changes could be attributed either to the cohort effects or to the larger impact of the labour market shocks on younger than on older cohorts of workers. In the same line of thought, Freeman (1975) put forward the "active labour market" hypothesis, which postulates that changes in the labour market conditions, such as changes in the supply and demand for skills, affect mainly new entrants in the labour market. To account for these cohort effects, these models considered also cohort specific loading factors or shifters on both components, which allow the parameters of the process to change with cohort.

$Y_{i t}=\gamma_{1 c} \lambda_{1 t} \mu_{i t}+\gamma_{2 c} \lambda_{2 t} v_{i t}$

where $\gamma_{j c}, j=1,2$ are cohort specific loading factors.

Secondly, regarding the permanent component, some studies brought evidence in favour of the "random growth rate model"1 or the "profile heterogeneity model": (Hause, 1977; Lillard and Weiss, 1979; MaCurdy, 1982; Baker, 1997; Cappellari, 2003; Sologon and O'Donoghue, 2009a, 2009c). According to this model, which is consistent with labour market theories such as human capital, and matching models (Mincer, 1974; Hause, 1980), each individual has a unique age-

${ }^{1} \mu_{i t}=\mu_{i}+\varphi_{i}$ age $_{i t}, \quad \mu_{i}: \operatorname{iid}\left(0, \sigma_{\mu}^{2}\right), \quad \varphi_{i}: \operatorname{iid}\left(0, \sigma_{\varphi}^{2}\right), \quad E\left(\mu_{i}, \varphi_{i}\right)=\sigma_{\mu \varphi}$. The variances $\sigma_{\mu}^{2}$ and $\sigma_{\varphi}^{2}$ capture individual heterogeneity with respect to time-invariant characteristics and age-earnings profiles. A positive covariance between $\mu_{i}$ and $\varphi_{i}$ implies a rising inequality in the permanent component of earnings over the life cycle, which is consistent with the school-matching models. A negative covariance implies that the two sources of heterogeneity offset each other, which is consistent with the on-the-job training. A negative covariance is expected to generate mobility within the distribution of the permanent component of earnings. Cappellari, L. (2003). 
earning profile with an individual specific intercept (initial earnings) and slope (earnings growth) that may be systematically related.

An alternative/additional specification for the permanent component of earnings is the "random walk model", or the "unit root model", which is used in the literature to accommodate earnings shocks that might have permanent effects. (MaCurdy 1982; Abowd and Card 1989; Moffitt and Gottschalk 1995; Baker 1997; Dickens 2000; Sologon and O'Donoghue 2009a, 2009b).

Thirdly, regarding the transitory component of earnings, previous research has brought evidence that transitory earnings are serially correlated. Therefore, a more general autocorrelation structure is called for that relaxes the restriction on $v_{i t}{ }^{\prime} s$ from the canonical model. For the construction of such a structure, longitudinal studies on earnings dynamics turned to error processes from the literature on time series analysis. Based on MaCurdy (1982), the structure of the transitory component, $v_{i t}$, is assumed to follow an $\operatorname{ARMA}(\mathrm{p}, \mathrm{q})$ process $^{3}$.

\subsubsection{Earnings Mobility}

Another aspect relevant for the evolution of earnings differentials is earnings mobility, defined by Katz and Autor (1999) as the rate at which individuals shift positions in the earnings distribution. Earnings mobility is closely related to the importance of the permanent and transitory components in earnings variation. A large contribution of the permanent component implies that individual earnings are highly correlated over time and individuals do not change their income position to a large extent experiencing low rates of earnings mobility. Therefore, the changes in earnings mobility are determined by the extent to which changes in cross-sectional inequality are driven by changes in the permanent or transitory variance.

Earnings mobility is a very complex phenomenon, and the ways of measuring it are diverse. We look at the degree of immobility, measured by the ratio between permanent and transitory inequality, following Kalwij and Alessie (2003). This measure offers also a summary of the

${ }^{2} u_{i a}=u_{i, a-1}+\pi_{i a}, \quad \pi_{i a}: i i d\left(0, \sigma_{\pi}^{2}\right), \quad E\left(u_{i, a-1}, \pi_{i a}\right)=0$ The current value depends on the one from the previous age and an innovation term $\pi_{i a}$, which accommodates any permanent re-ranking of individuals in the earnings distribution. The high persistency of the unit root model might result from low rates of depreciation on human capital investments or labour market conditions through implicit contacts. (Baker 1997)

$\sum_{3=0}^{p} \rho_{j} v_{i t-j}=\sum_{j=0}^{q} \theta_{j} \varepsilon_{i t-j}, \quad \varepsilon_{i t}: \operatorname{iid}\left(0, \sigma_{\varepsilon}^{2}\right), \quad v_{i 0}:\left(0, \sigma_{0, c}^{2}\right)$ 
evolution in the structure of inequality: a(n) decrease (increase) in the immobility ratio indicates an increase (decrease) in earnings mobility, equivalent with a(n) decrease (increase) in the relative share of permanent differentials in the overall inequality. This mobility index captures non-directional earnings movements and can be interpreted as the opportunity to improve one's position in the distribution of lifetime earnings.

An increase in cross-sectional inequality accompanied by a decrease in earnings mobility is expected to have negative implications for long-run or lifetime earnings differentials, as it shows that over time low wage men get worse off both in terms of their relative earnings position and in terms of their opportunity to escape low wage trap. Thus it is reasonable to expect that crosssectional earnings differentials will be enhanced in a lifetime perspective.

An increase in cross-sectional inequality accompanied by an increase in earnings mobility has uncertain implications for long-run or lifetime earnings differentials. Over time low wage men get worse off in terms of their relative earnings position, but better off in terms of the opportunity to escape low wage trap in a lifetime perspective. Thus earnings mobility could either enhance or decrease lifetime earnings differentials compared with the cross-sectional ones.

A decrease in cross-sectional inequality accompanied by an increase in earnings mobility is expected to have positive implications for lifetime earnings differentials, as over time low wage men better their relative earnings position and their opportunity to escape low wage trap in a lifetime perspective. Thus, lifetime earnings differentials are expected to be reduced compared with annual differentials.

A decrease in cross-sectional inequality accompanied by a decrease in earnings mobility has uncertain implications for lifetime earnings differentials, as over time low wage men get better off in terms of their relative earnings position, but worse off in terms of their opportunity to escape low wage trap in a lifetime perspective. Thus, lifetime earnings differentials could be either reduced or enhanced compared with annual differentials.

It becomes obvious that the question regarding the link between earnings mobility and earnings inequality does not have a straight forward answer and mobility is not always beneficial. It depends on the underlying factors: "changes in earnings mobility could either work to offset or to increase changes in cross-sectional dispersion", with very different implications for permanent earnings inequality. Dickens (1999) Nonetheless, no controversy surrounds the fact that mobility 
is beneficial when it helps low paid individuals to improve their income position in the long-term or lifetime income distribution.

\subsubsection{Linking labour market policies and institutions with outcomes}

To understand the differences in labour market outcomes - permanent inequality, transitory inequality and earnings mobility - across the 14 EU countries we relate to factors from the "SDI explanation of change" - the institutional setting. To our knowledge no study before tried to determine the possible links between these outcomes and the main labour market policy and institutional factors. Moreover, there is no specific theory that can explain this link. Therefore, we build our expectations based on existing labour market theories and empirical findings regarding the impact of the SDI factors on overall earnings inequality.

The rise of inequality in the permanent component of earnings may be consistent with increasing returns to education, on-the-job training and other persistent abilities that are among the main determinants of the permanent component of earnings, meaning enhanced relative earnings position of the highly skilled individuals. ((Mincer, 1957, 1958, 1962, 1974; Hause, 1980). Thus the increase in permanent differentials may be driven by an increase in the relative demand for high-skilled labour which has outstripped the rise in supply.

Among the factors that determine shifts in relative demand are skill-biased technological changes, which enhances the relative earnings position of the highly-skilled workers, the increase in prices of the other products, which imply changes in product demands, and forces of globalization, such as reduction in trade barriers and outsourcing. (Fortin and Lemieux, 1997; Topel, 1997) A possible solution to the economic and social problem of rising permanent earnings differentials is to enhance the supply of high skill labour through investment in human capital to match the rise in the demand. (Topel 1997) Shifts in the supply demand are determined by cohort variation, changes in access to education and immigration.

Another factor is the change in the interest rate. Weizsacker (1993) analysed its influence on permanent inequality and concluded that an increase in the interest rate leads to a decrease in permanent inequality within the younger cohort and to a rise in permanent inequality in the older cohorts. 
As underlined by Katz and Autor (1999), the rise of earnings instability appears to be "a bit of a puzzle for hypotheses only emphasizing rising skills prices associated with increased growth in the demand for skills relative to the supply of skills". However, some explanations could be formulated. The increase in the inequality of the transitory component of earnings may be attributed to increased earnings exposure to macroeconomic shocks and/or a rise in the temporary workforce which increases earnings exposure to shocks, increased labour market instability, increased competitiveness, globalization, increasing international capital mobility, and to the weakening of the labour market institutions (e.g. unions, government wage regulation, and internal labour markets) in filtering the impact of these shocks on earnings. (Rodrik, 1997; Katz and Autor, 1999)

Some of the factors influencing directly permanent inequality might impact also transitory inequality. E.g. a period of skill-biased technological change with the spread of new technologies can, on the one hand, increase the demand for skills, and on the other hand increase earnings instability, as firms might face uncertainty with respect to the abilities of the individual workers. (Katz and Autor 1999).

Overall, the increase in the return to persistent skills is expected to have a much larger impact on long-run earnings inequality than an increase in the transitory component of earnings. (Katz and Autor 1999; Moffitt and Gottschalk 2002) Across age groups, as postulated by Freeman's (1975) "active labour market hypothesis", similarly with overall income, supply and demand factors together with the other macroeconomic shocks are expected to have the largest effect on the youngest generations of workers. Moreover the limiting impact of these factors on both inequality components is expected to be lower for younger workers, which have a weaker attachment to the labour market compared with senior workers.

The discussion is summarized in Figure 1. Permanent earnings inequality within birth cohorts is the result of the interactions between ability distributions, lifecycle decisions, economic structures and labour market policy and institutions. Transitory inequality within birth cohorts is expected to be driven mainly by random macroeconomic and individual-specific shocks, but its final evolution depends on the ability of the labour market policy and institutions to minimize its increase. 
Once we account for all these factors influencing each component, the complexity of the mechanism determining earnings mobility is revealed. The evolution of mobility, which reflects the evolution in the structure of inequality, depends on which component is influenced the most: an increase in mobility is triggered when transitory inequality becomes relatively more important than permanent differentials in the composition of overall inequality and people manage to change their position in the income distribution. An equal relative increase in both components suggests an increase in earnings instability with no change in mobility, which might point to an increase in persistent differentials which are exacerbated by transitory differentials.

\section{Policies and Institutions - permanent effects}

Economic theory and previous empirical studies have identified a number of possible policy and institutional determinants of inequality. These include inter alia trade union bargaining power and the structure of collective bargaining, employment protection legislation (EPL), anticompetitive product market regulation (PMR), taxes, active labour market policies (ALMPs) and unemployment benefits. We investigate to what extent the changes in permanent earnings inequality, transitory earnings variability and earnings mobility are related to changes in these policy and institutional variables.

(i) Trade unions and the structure of collective bargaining

Unionization and collective bargaining represent important institutional factors in the determination of wages and implicitly earnings inequality. It is well recognized that the stated purpose of unions is to reduce earnings disparities, and covered workers earn significantly higher wages and have less volatile profiles than the uncovered ones. Hence, unionization could be expected to lower transitory differentials.

Unions affect wage dispersion indirectly, mainly through their impact on training and minimum wage. By forcing employers to provide training to their employees, they increase the employees' human capital and adaptability to new technologies. (Aghion and Williamson 2001) Thus unionization stimulates earnings mobility and increases employees' opportunity to improve their position in the permanent earnings distribution. Hence permanent earnings inequality can be reduced at any given rate of technical change. (Aghion and Williamson 2001) In conclusion, unionization could be expected to lower both permanent and enhance earnings mobility. 
However, even if unions decrease within-group earnings disparities, they may still increase both overall transitory and permanent inequality by increasing between-group wage differentials, meaning between those unionized and non-unionized. Thus, the impact of unionization depends also on the wage gap between unionized and non-unionised workers.

Furthermore, strong trade unions have the ability to increase wages above market-clearing levels at the cost of lower employment, which affects mainly workers with more elastic labour supply, such as younger workers, women and older workers. (Bertola, Blau, and Kahn, 2002) Hence, by pushing these workers out of the labour market, both components might be expected to decrease for those still in the labour market. Similarly with overall inequality, because of these potentially offsetting effects, the impact of unionization on permanent differentials, transitory differentials and earnings mobility can only be resolved empirically. (Fortin and Lemieux 1997)

Existing studies brought evidence that a high union density is usually associated with a low overall earnings inequality, which results from claims for high wages and earnings stability for covered workers. OECD (2004)

Nonetheless, it has long been argued that, in practice, union influence on wage formation depends on the structure of collective bargaining. On the one hand, a low degree of corporatism, meaning a decentralized wage bargaining at the firm level is expected to prevent excessive wage claims since this would lead to a loss of market shares to competitors with detrimental effects on employment. This implies that wages are less uniformly distributed, meaning that there is a higher dispersion in the returns to skills and in earnings variability.(Bassanini and Duval 2006) Therefore we can expect countries with low degrees of corporatism to display high levels of permanent earnings inequality, a high variability and a high degree of earnings mobility.

The impact of coupling a high union density with low corporatism can be argued either way. On the one hand, a high or increasing union density could decrease the level of the high permanent and transitory inequality associated with low corporatism and might stimulate earnings mobility. On the other hand, even if union density increases, in the absence of coordination, this might lead to even higher permanent and transitory differentials. Moreover, as mentioned above, the wage gap between those unionized and those non-unionized is expected to play a significant role as well in determining the final outcome. 
On the other hand, a very high degree of corporatism, meaning a very centralized and coordinated bargaining system is associated with a compressed wage structure across qualification levels because it is expected to exclude low skilled workers from the labour market. (Calmfors, 1993). Therefore we can expect permanent and transitory earnings inequality and mobility to be lower the higher is the degree of centralization/coordination and the effect to be stronger the stronger the unionization. Again, the union-non-union wage gap might play a role.

Nonetheless, a very high degree of corporatism is more likely to lead to wage modernization, because they induce unions to internalize the detrimental macroeconomic effects of excessive wage pressure by restraining the wage demands. In this situation the degree of permanent inequality under high corporatism might be similar as under low corporatism. Thus the relationship between the degree of corporatism and wages may not be monotonic, but follow a "U-shaped" pattern, similar with employment.

For employment, an intermediate level of corporatism is expected to trigger the worst labour market outcomes, as they do not benefit from either of the advantages of low and high corporatism: when bargaining takes place at the firm level (without coordination), the high elasticity of demand in the product market implies that any price increase resulting from higher wages would result in severe drops both in output and employment. By contrast, when the bargaining takes place at the industry level, unions are able to secure higher wages because product demand elasticity is generally lower, given the lower substitution possibilities compared with the firm level. ((Bassanini and Duval, 2006b, 2006a); Calmfors and Driffill, 1988). Thus it is reasonable to expect both higher transitory and permanent differentials for intermediate levels of corporatism compared with low and high levels. Given the high earnings volatility, we might expect also higher levels of earnings mobility for intermediate corporatism compared with the other two.

(ii) Employment protection legislation (EPL)

EPL is one of the factors which affect the elasticity of labour demand to the bargained wage. It is considered to be a key factor in generating labour market rigidity by incurring costs to employers when dismissing workers. Two consequences emerge. On the one hand, employers might offer lower wages in order to compensate for the firing costs. On the other hand, employees might feel better protected and push for higher wages, which in turn puts a pressure on employers. 
Employers will reduce hiring rates, thus increase unemployment spells. Consequently, the cost of unemployment becomes too high, which might create an incentive for employees to accept lower wages to maintain their wage. Hence the equilibrium is restored. (Blanchard, 1999) Therefore, theory predicts that EPL increases the cost of hiring and of layoffs, and consequently lowers labour turnover, which might reduce transitory inequality and earnings mobility, and wages, which might reduce permanent inequality. This is consistent with OECD (2004) findings, which state that a strict EPL is usually associated with a low overall inequality. Moreover, the low turnover is expected to affect mainly workers with temporary contracts, because they have a weaker protection in the labour market.

In conclusion, an increase in the strictness of the EPL can be expected to decrease both permanent and transitory earnings inequality and earnings mobility. However, the overall impact of the EPL depends on the difference in regulating regular (EPLR) and temporary contracts (EPLT), which affects the labour market structure with respect to the type of contract. A higher share of transitory contracts is expected to bring along a higher transitory inequality, given the higher exposure of these workers to the economic shocks.

If a strict EPLR coexists with a low EPLT, this represents a strong disincentive for employers to train temporary workers, as the cost of their layoff is low. Consequently, temporary workers are trapped in this type of contracts, without a chance towards permanent contracts, meaning without a chance towards increasing their human capital and, at the same time, facing more earnings instability under the impact of macroeconomic shocks. However, this type of earnings instability is not expected to increase mobility rates that could help these individuals improve their relative position in the distribution of lifetime earnings. At the same time, workers with a permanent contract might benefit from higher bargaining power and might push towards higher wages. Thereby, permanent differentials and earnings instability are expected to be enhanced, and earnings mobility to be reduced by an increase in the relative difference between EPLR and EPLT.

(iii)Tax wedge

An increase in the tax wedge, defined as the sum of the personal income tax and all social security contributions as a percentage of total labour cost, results in employers paying more and employees receiving less. The resulting impact on permanent inequality is twofold. On the one 
hand, tax wedge influences permanent inequality through its influence on human capital price. An increase in the tax wedge lowers human capital price. Weizsacker (1993) proved within the context of an explicit comparative dynamic inequality analysis that a decrease in human capital price results in a decrease in permanent inequality within age groups.

On the other hand, an increase in the tax wedge suggests that the cost to employers increases to a larger extent than the increase of the wage offered. This has detrimental effects especially for employment, pushing minimum wage workers, for which the rise in payroll taxes cannot be shifted onto, into unemployment. (Bassanini and Duval, 2006b, 2006a) Thus an increase in the tax wedge is expected to push low wage workers into unemployment and to decrease permanent earnings inequality for the working population. These effects might be exacerbated by strong unions. Similarly with the findings for employment, its effects are expected to depend also on the degree of corporatism. No direct effect is expected on transitory income.

(iv)Product market regulation (PMR)

A good example of the impact of product market regulation on wage inequality is the comparison between public and private sector: the public sector, which is highly regulated, displays a more compressed earnings structure. Hence, we expect highly regulated sectors to display reduced permanent and transitory differentials.

Lower product market regulations (PMR) are expected to determine an increase in competition in the previously regulated sectors, and consequently lower market rents, which in turn determine lower wage claims, aimed to close the gap between productivity and real wages that generates unemployment. Therefore a decrease in product market regulation is expected to shift labour demand, increase its elasticity to wages, increase the returns to skills, and consequently increase permanent differentials in the previously regulated sectors. At the same time, increased competition is expected to increase transitory inequality. In the same line of thought, more competitive environments are expected to determine higher levels of earnings mobility.

These effects might hold in the previously regulated sectors, but the impact on the overall level of inequality, including also those which were not regulated, might be different. The final effect depends on a large extent on the ex-ante wage gap between regulated and non-regulated sectors. Moreover, interaction effects with other institutions cannot be neglected. For example, previous findings showed that the effect of deregulation on wage differentials depend on union density 
and the degree of corporatism. For example, Fortin and Lemieux (1997) found that deregulation increases overall inequality, but the effect is larger among unionized male workers.

(v) Active labour market policies (ALMPs)

Active Labour Market Programs (ALMP), which typically consist of job placement services and labour market programmes such as job-search, vocational training or hiring subsidies can reduce permanent earnings differentials by improving the efficiency of the job matching process and by enhancing the work experience and skills of the unemployed. Thus by increasing human capital of low wage individuals and decreasing permanent wage differentials, ALMP is expected to increase their wage mobility, helping them improve their position in the distribution of permanent earnings.

However, these reintegrated workers are the ones with least protection in the labour market and they are expected to be the most affected by macroeconomic shocks. Hence, in the face of macroeconomic shocks, their presence in the labour market might exacerbate permanent and transitory differentials.

Another aspect to be considered are interactions with other factors: the effects of the ALMP depend on the other labour market policies and institutions. For example, a strict EPL is expected to dampen the effect of active labour market policies aimed to reintegrate the unemployed into the labour market (Bassanini and Duval, 2006b, 2006a). On the one hand, the increase in the ALMP increases employability and on the other hand the low EPL facilitates their labour market reintegration. Hence, an increase in ALMP coupled with a low or decreasing EPL could be expected to reduce permanent differentials and increase earnings mobility.

(vi)Unemployment benefits

The expected impacts of the unemployment benefits on labour market outcomes are not so straightforward. On the one hand, generous unemployment benefits are expected to weaken the job-search intensity and decrease the employability and human capital for the unemployed, thus increase permanent differentials. Moreover, generous unemployment benefits are expected to increase the economic cost of employment, which in turn may put an upward pressure on worker's wage claims and exacerbate the increase in permanent earnings dispersion. 
On the other hand, longer and more generous unemployment benefits represent incentives not to accept low-paid jobs and improve the job-matching, thus increasing the likelihood of a more stable employment and earnings patterns. (Bassanini and Duval, 2006b, 2006a) In this situation, both transitory and permanent differentials are expected to be reduced. Moreover, if they are coupled with active labour market programs they are expected to increase human capital even further, thereby reducing permanent differentials.

Regarding the interactions between all these policy and institutional factors that are expected to impact permanent inequality, transitory inequality and earnings mobility, based on the standard wage-setting/price-setting (WS/PS) model (Layard, Nickell, and Jackman, 1991), any factor that affects the slope of the wage-setting curve - the elasticity of wage claims to employment (e.g. unemployment benefits, unionization, degree of corporatism, PMR) and/or the slope of the pricesetting curve - elasticity of labour demand to bargaining wage (e.g EPL, PMR, tax wedge) may be expected to interact with policies and institutions that affect the level of the wage-setting level of wage claims (e.g. unemployment benefits) and the level of price-setting curve - level of labour demand (e.g. PMR). (Bassanini and Duval, 2006b, 2006a)

Similar with the conclusions reached by Bassanini and Duval (2006a, 2006b) regarding the impact of the labour market institutional and policy factors, the overall lessons that emerge are that, in theory, all possible interactions across policies and institutions can affect permanent inequality, transitory inequality and earnings mobility. And which policies complement each other should be established empirically.

\section{Interactions between polices, institutions and macroeconomic shocks - temporary effects}

From what has been presented so far, policies and institutions appear to play a major role in shaping primarily permanent differentials and earnings mobility. However, for transitory differentials and earnings mobility a big part of the story is missing. Besides their permanent effects, policies and institutions may also have a temporary impact via their interactions with a series of macroeconomic shocks which have affected the OECD countries. We are going to consider the impact of globalization, technological changes, interest rate, labour demand shocks, aggregate supply and demand shocks. These macroeconomic shocks are expected to explain to a larger extent the evolution of the transitory variance and earnings mobility compared with 
permanent variance, which appears to be shaped at a larger extent by institutional and policy factors.

The effects of these shocks on all three elements are expected to be "filtered" by the labour market policies and institutions, which are put in place to protect earnings against the exposure to the possible adverse effects of these shocks.

We expect that strong unionization, a high degree of corporatism, strict EPL, strict PMR and high unemployment benefits will have a dampening effect on the sensitivity of wages to general economic conditions, thus limiting the increase or even reducing transitory variance, and thus reducing earnings mobility. The effectiveness of these policies and institutions is expected to be lower for the youngest cohort compared with more experienced workers, as younger workers are expected to be affected the most by demand and supply shocks.

\section{DATA}

The estimation of the permanent variance, transitory variance and earnings mobility is done using the European Community Household Panel (ECHP) ${ }^{4}$ over the period 1994-2001 for 14 EU countries. Not all countries are present for all waves. Luxembourg and Austria are observed between 1995 and 2001 and Finland between 1996 and 2001. Following the tradition of previous studies, the analysis focuses only on men.

A special problem with panel data is that of attrition over time, as individuals are lost at successive dates causing the panel to decline in size and raising the problem of representativeness. Several papers analysed the extent and the determinants of panel attrition in ECHP. Behr, Bellgardt and Rendtel (2005) found that the extent and the determinants of panel attrition vary between countries and across waves within one country, but these differences do not bias the analysis of income or the ranking of the national results. Ayala, Navrro and Sastre (2006) assessed the effects of panel attrition on income mobility comparisons for some EU countries from ECHP. The results show that ECHP attrition is characterized by a certain degree of selectivity, but only affecting some variables and some countries. Moreover, the income mobility indicators show certain sensitivity to the weighting system.

4 The European Community Household Panel provided by Eurostat via the Department of Applied Economics at the Université Libre de Bruxelles. 
In this paper, the weighting system applied to correct for the attrition bias is the one recommended by Eurostat, namely using the "base weights" of the last wave observed for each individual, bounded between 0.25 and 10. The dataset is scaled up to a multiplicative constant ${ }^{5}$ of the base weights of the last year observed for each individual.

For the empirical analysis, individuals are categorized into four birth cohorts, which are followed through time. Ideally, one should use birth cohorts formed from people born in a particular year. The limited number of observations forces us to group more birth years in one birth cohort. The first birth cohort are people born between 1940-1950, the second one people born between 19511960, the third cohort people born between 1961-1970 and lastly people born between 19711981. This grouping allows the analysis of the earnings covariance structure for individuals of the same age, followed at different points in time.

For this study we use real log hourly wage adjusted for CPI of male workers aged 20 to 57, born between 1940 and 1981. Only observations with hourly wage lower than 50 Euros and higher than 1 Euro were considered in the analysis. The resulting sample for each country is an unbalanced panel. The choice of using unbalanced panels for estimating the covariance structure of earnings is motivated by the need to mitigate the potential overestimation of earnings persistence that would arise from balanced panels where the estimation is based only on people that have positive earnings for the entire sample period.

Details on the number of observations and mean yearly hourly earnings are provided in Table 1 . Mean hourly earnings appear to increase in all countries except for Austria where it records a slight decrease. Based on Sologon and O'Donoghue (2009a), the highest attrition rates from one year to the next are recorded in Ireland, Italy, Greece, Spain and Portugal, where, on average, less than $60 \%$ of those who were in the sample in the previous year reported positive earnings in the current year. For more descriptive statistics please refer to Sologon and O'Donoghue (2009a, 2009b).

The link between the evolution of the two inequality components and the labour market policies and institutions is investigated using the estimated components from the first part of the analysis and the OECD data on the labour market indicators, which is a combination of two data sets. The

5 The multiplicative constant equals e.g. $\mathrm{p}^{*}$ (Population above 16/Sample Population). The ratio $\mathrm{p}$ varies across countries so that sensible samples are obtained. It ranges between 0.001-0.01. 
first dataset is the one used by Bassanini and Duval (2006a, 2006b) ${ }^{6}$ and the second one is the Lindert-Allard OECD data set 1950-2001 ${ }^{7}$.

The following institutional variables are included in the analysis: employment protection legislation overall (EPL), for temporary (EPLT) and for regular contracts (EPLR), the relative difference between EPLR and EPLT, trade union density, product market regulation (PMR), tax wedge, degree of corporatism, degree of bargaining coverage, average unemployment benefit replacement rate and spending on active labour market programmes (ALMP). The macroeconomic shock variables included are: labour demand shock, terms of trade shock, total factor production shock, real interest shock, aggregate demand shock and aggregate supply shock. These variables are observed at the country level, over the period 1994-2001.

A description of the variables is included in Table 2. For a more detailed description, please refer to Bassanini and Duval (2006a, 2006b) and the Lindert-Allard OECD data sets 1950-2001. The summary statistics of the institutional variables and shock variables are illustrated in Table 3 . Luxembourg and Greece have some missing institutional and shock variables and they are dropped from the final estimations. Portugal, Denmark and Ireland record some missing values for labour demand shock.

Additional control variables by cohort are included in the final estimations estimation: the share of university degrees, the share of upper-secondary degrees, share of permanent contracts, share of private employees and share of employees by occupation. The summary statistics for the control variables are presented in Table 5 .

\footnotetext{
${ }^{6}$ The data was provided by email from the authors.

${ }^{7} \mathrm{http} / / /$ www.econ.ucdavis.edu/faculty/fzlinder/OECD\%20data.htm
} 


\section{ECONOMETRIC SPECIFICATIONS AND ESTIMATION METHODS}

The aim of this section is twofold: first, to fit a parsimonious model to the autocovariance structure of earnings for all countries, decompose overall earnings inequality into its permanent and transitory components and compute earnings immobility; second to estimate the relationship between these estimated components and the main labour market policy and institutional factors.

\subsection{Econometric specifications and Estimation methods of covariance structures}

\subsubsection{Econometric Earnings Specification}

The methodology used to estimate earnings inequality, its permanent and transitory component, and earnings mobility by cohorts and for each country follows Sologon and O'Donoghue (2009b, 2009a, 2009c). This paper represents a follow-up of their analysis. We use the same data and the models identified by Sologon and O'Donoghue (2009b, 2009a, 2009c) as the best fit for each country to estimate the two inequality components and earnings mobility. A summary of this methodology is provided below.

The inspection of the covariance structure of earnings, included in section 5.1, suggests the following features of the data, which must be incorporated in the model:

(vii) the elements of the autocovariance structure decrease with the lag at a decreasing rate and

(viii) they converge gradually at a positive level;

(ix) the lag-1 autocovariance drops to a larger extent compared with higher order autocovariances, which decline more gradually;

(x) the autocovariances and mean earnings vary over the sample period, so they cannot be assumed to be stationary over sample period;

(xi) the autocovariances vary with age controlling for the period effect, hence they cannot be assumed to be stationary over the life cycle;

(xii) the variance covariance structure appears to be cohort specific.

Each of the above features are incorporated in the general model. Feature (i) suggests the presence of an $\operatorname{AR}(1)$ process, but the presence of feature (iii) calls for an ARMA $(1,1)$ process. Feature (ii) can be captured by the presence of the permanent component. Feature (iv) is captured by incorporating period specific parameters, meaning that the permanent individual component 
and the transitory component of earnings are allowed to vary with time. The life cycle nonstationarity of the autocovariance structure of earnings in feature (v) is captured by modelling the permanent individual component as a random walk and/or random growth in age. Cohort heterogeneity is incorporate by parameters that allow the permanent and transitory components to vary between cohorts.

The following general specification encompasses all the relevant aspects of earnings dynamics considered above.

$$
\begin{aligned}
& Y_{i c t}-\overline{Y_{c t}}=r_{i c t}=\gamma_{1 c} \lambda_{1 t}\left[\mu_{i}+\varphi_{i} a g e_{i t}+u_{i a t}\right]+\gamma_{2 c} \lambda_{2 t} v_{i t}, \quad t=1, \ldots, T_{i}, \quad i=1, \ldots, N_{c} \\
& \mu_{i} \sim \operatorname{iid}\left(0, \sigma_{\mu}^{2}\right), \quad \varphi_{i} \sim \operatorname{iid}\left(0, \sigma_{\varphi}^{2}\right), \quad E\left(\mu_{i}, \varphi_{i}\right)=\sigma_{\mu \varphi} \\
& u_{i a t}=u_{i, a-1, t-1}+\pi_{i a}, \quad \pi_{i a} \sim \operatorname{iid}\left(0, \sigma_{\pi}^{2}\right), \quad E\left(u_{i, a-1, t-1}, \pi_{i a t}\right)=0 \\
& v_{i t}=\rho v_{i t-1}+\varepsilon_{i t}+\theta \varepsilon_{i t-1}, \quad \varepsilon_{i t} \sim\left(0, \sigma_{\varepsilon}^{2}\right), \quad v_{i 0} \sim\left(0, \sigma_{0, c}^{2}\right)
\end{aligned}
$$

$Y_{i c t}$ is the natural logarithm of real hourly earnings of the $i$-th individual, from the $c$-th cohort in the $t$-th year, $\overline{Y_{c t}}$ is the year-cohort specific mean and $r_{i c t}$ is an error term which represents the individual-specific deviation from the year-cohort specific mean. The demeaned earnings $r_{i c t}$ are assumed to be independently distributed across individuals, but autocorrelated over time. Earnings differentials within each cohort can be characterised by modelling the covariance structure of individual earnings $\operatorname{VarCov}\left(Y_{i c t}\right)=E\left(r_{i c t}, r_{i c t-s}\right), s=0, \ldots, T_{c}-t_{0 c} \cdot$.

Based on equation (5), earnings are decomposed into a permanent component $\gamma_{1 c} \lambda_{1 t}\left[\mu_{i}+\varphi_{i} a g e_{i t}+u_{i a t}\right]$ and a transitory component $\gamma_{2 c} \lambda_{2 t} v_{i t}$. The component $\mu_{i}+\varphi_{i} a g e_{i t}$ models an individual profile heterogeneity as a function of age - the random growth model (Baker 1997, Moffitt and Gottschalk 1995), where $\mu_{i}$ and $\varphi_{i}$ are time invariant individual intercept and slopes with variance $\sigma_{\mu}^{2}$ and $\sigma_{\varphi}^{2}$. Besides the random vector of intercepts and slopes $\left(\mu_{i}, \varphi_{i}\right)$ the parameterization of individual earnings dynamics includes also a random walk process (Equation (6)). (Moffit and Gottschalk 1995, Baker and Solon 2003) The variance of the first period shock

\footnotetext{
${ }^{8} T_{c}$ and $t_{0 c}$ represent the total number of years and the first year observed for each cohort.
} 
(assumed to be at age 20, which is also the lowest age observed in our dataset) is estimated together with the $\sigma_{\mu}^{2}$ and is considered part of the unobserved heterogeneity.

Equation (7) specifies the transitory component of earnings which evolves as an ARMA(1,1) process, where the serial correlation $\rho$ parameter captures the decreasing rate of decay of the covariances with the lag, the moving-average parameter $\theta$ captures the sharp drop of the lag-1 autocovariance compared with the other autocovariances, and $\varepsilon_{i t}$ are white-noise mean-reverting transitory shocks. The variance $\sigma_{0, c}^{2}$ measures the volatility of shocks at the start of the sample period for each cohort, $\sigma_{\varepsilon}^{2}$ the volatility of shocks in subsequent years and $\rho$ the persistence of shocks. Measurement error in this model is captured by the transitory component.

When working with $\operatorname{ARMA}(p, q)$ processes in the context of panel data, MaCurdy $(1981,1982)$ and Anderson and Hsiao (1982) underlined the need for a treatment of initial conditions ${ }^{9}$. Following MaCurdy (1981, 1982) and Sologon and O'Donoghue (2009b, 2009a, 2009c), we treat the initial transitory variances of the 4 cohorts as 4 additional parameters to be estimated.

The non-stationary pattern of earnings is accommodated using time specific loading factors, both on the permanent and transitory component of earnings, $\lambda_{k t, k=1,2 ; t=0,7}$, normalized to 1 in the first wave for identification ${ }^{10}$. Cohort heterogeneity is accommodated by allowing both the permanent and the transitory component to vary by cohort. $\gamma_{j c}, j=1,2$ are cohort loading factor, normalized to 1 for the oldest cohort born for identification.

\subsubsection{Specification and Estimation of the Covariance Structure of Earnings}

Following Sologon \& O’Donoghue (2009), the covariance structure for the first sample period takes the form:

$$
\left.\operatorname{Var}\left(Y_{i c 0}\right)=E\left(r_{i c 0} r_{i c 0}\right)=\sigma_{\mu}^{2}+\sigma_{\varphi}^{2} E\left(\operatorname{age}_{i 0}^{2}\right)+2 \operatorname{cov}\left(\mu_{i} \varphi_{i}\right) E\left(\text { age }_{i 0}\right)+(a-20) \sigma_{\pi}^{2}+\sigma_{0, c}^{2}\right) \text { if } t=0 \text { (8) }
$$

The covariance structure for subsequent years can be expressed as follows:

\footnotetext{
${ }^{9}$ See Macurdy(1982, page 92/93)

${ }^{10} 1994$ refers to $\mathrm{t}=0$
} 


$$
\begin{aligned}
\operatorname{Var}\left(Y_{i c t}\right)=E\left(r_{i c t} r_{i c t}\right) & =\gamma_{1 c}^{2} \lambda_{1 t}^{2}\left[\sigma_{\mu}^{2}+\sigma_{\varphi}^{2} E\left(a g e_{i t}^{2}\right)+2 \operatorname{cov}\left(\mu_{i} \varphi_{i}\right) E\left(a g e_{i t}\right)+\sigma_{\pi}^{2}\left(a_{t}-20\right)^{2}\right]+ \\
& +\gamma_{2 c}^{2} \lambda_{2 t}^{2}\left[\rho^{2} \operatorname{Var}\left(v_{i t-1}\right)+\sigma_{\varepsilon}^{2}\left(1+2 \rho \theta+\theta^{2}\right)\right] \text { if } t>0
\end{aligned}
$$

$\operatorname{Cov}\left(Y_{i c t} Y_{i c t-s}\right)=E\left(r_{i c t} r_{i c t-s}\right)$

$=\gamma_{1 c}^{2} \lambda_{1 t}^{2}\left\{\sigma_{\mu}^{2}+\sigma_{\varphi}^{2} E\left(a g e_{i t}\right) E\left(a g e_{i t-s}\right)+\operatorname{cov}\left(\mu_{i} \varphi_{i}\right)\left[E\left(a g e_{i t}\right)+E\left(a g e_{i t-s}\right)\right]+\sigma_{\pi}^{2}\left(a_{t}-20\right)\left(a_{t}-s-20\right)\right\}+(10$

$+\gamma_{2 c}^{2} \lambda_{2 t} \lambda_{2 t-s}\left[\rho \operatorname{Cov}\left(v_{i t-1}, v_{i t-s}\right)\right]$ if $t>0 \& s>1$

$\operatorname{Cov}\left(Y_{i c t} Y_{i c t-1}\right)=E\left(r_{i c t} r_{i c t-1}\right)=$

$=\gamma_{1 c}^{2} \lambda_{1 t}^{2}\left\{\sigma_{\mu}^{2}+\sigma_{\varphi}^{2} E\left(\right.\right.$ age $\left._{i t}\right) E\left(\right.$ age $\left._{i t-1}\right)+\operatorname{cov}\left(\mu_{i} \varphi_{i}\right)\left[E\left(\right.\right.$ age $\left.\left.\left._{i t}\right)+E\left(a g e_{i t-1}\right)\right]+\sigma_{\pi}^{2}\left(a_{t}-20\right)\left(a_{t}-1-20\right)\right\}$

$\left.+\gamma_{2 c}^{2} \lambda_{2 t} \lambda_{2 t-1}\left\{\rho \operatorname{Var}\left(v_{i t-1}\right)+\theta \sigma_{\varepsilon}^{2}\right)\right\}$ if $t>0 \& s=1$

Basically the parameters that are estimated

are: $\gamma_{1 c}, \lambda_{1 t}, \sigma_{\mu}^{2}, \sigma_{\varphi}^{2}, \operatorname{cov}\left(\mu_{i} \varphi_{i}\right), \sigma_{\pi}^{2}, \gamma_{2 c}, \lambda_{2 t}, \rho, \theta, \sigma_{\varepsilon}^{2}, \sigma_{0, c}^{2}, c=1, \ldots 4$.

The parameters of the models are fit to the covariance structure for each cohort by country using equally weighted minimum distance methods of estimation. The methodology used is the same as that utilized by Cappellari (2003), Baker and Solon (2003), Ramos (2003), Kalwij and Alessie (2003), Dickens (2000), Baker (1997), Abowd and Card (1989), Cervini, Ramos (2006) and Sologon and O'Donoghue (2009b, 2009a, 2009c) adapted to unbalanced panels.

This paper uses the specification that fit the data the best for each country, as found by Sologon and O'Donoghue (2009). For the complete description of the methodology and the strategy on model selection, please refer to Sologon and O'Donoghue (2009b, 2009a, 2009c).

\subsection{Estimation of the links between policy, institutions and outcomes}

This section describes the methodology used to estimate the relationships between labour market policy and institutional factors as independent variables and permanent inequality, transitory inequality and earnings mobility, as dependent variables. Each model is estimated independently, for all cohorts and countries pooled together. The unit of analysis is the cohort. Hence we have four cohorts for each country, observed between 1994-2001 ${ }^{11}$.

The analysis follows a general to specific strategy. First, we test whether policies interact with the overall institutional framework, controlling for the cohorts effects and for all the unobserved

${ }^{11}$ Exception are countries which are not observed for all eight waves, and consequently will have less observations. 
shocks. Second, we test whether there are any specific interactions between different institutional factors, and between the institutional factors and the observed aggregate shocks in shaping the pattern of the two inequality components and earnings mobility.

\subsubsection{Systemic Interactions}

In macroeconomic equations interactions between institutions are usually specified in a multiplicative form between deviations of institutions from their sample mean, which enables the interpretation of the marginal effects of each institution when the others are kept constant at the sample mean. Before analysing the specific cross-interactions between all institutions, we want to get a grasp of the systemic interactions, meaning the interactions between each institution and the overall institutional setting.

Systemic reform complementarity patterns are explored by estimating a separate non-linear equation for each labour market outcome, pooling all cohorts, where each institution is interacted with the overall institutional framework, defined as the sum of the direct effects of institutions.

$$
y_{i t}=\delta_{c} \tau_{t}\left(\sum_{k=1}^{K} v_{k} X_{k i t}+\sum_{j=1}^{J} \varphi_{j}\left(X_{k i t}-\overline{X_{k}}\right)\left(\sum_{k=1}^{K} v_{k}\left(X_{k i t}-\overline{X_{k}}\right)\right)+\mu_{i}+v_{i t}\right.
$$

$y_{i t}$ represents the labour market outcomes -permanent variance, temporary variance and wage immobility of the cohort $i$ in year $t$. The parameters $v_{k}, \varphi_{j}, \delta_{c}$ and $\tau_{t}$ are estimated simultaneously. $v_{k}$ denotes the direct effect of institution $X_{k}$ on $y_{i t}$, for a country with an average mix of policies and institutions, while $\varphi_{j}$ indicates the strength of the interaction between $X_{k}$ and the overall institutional framework, expressed as the sum of direct effect of policies and institutions, expressed in deviation form in the interaction. $X_{k}$ is measured at the country level. A negative and significant effect suggests that there is a systemic reform complementarity between $X_{k}$ and the overall framework in reducing permanent variance, temporary variance and earnings immobility, at the cohort level. $\delta_{c}$ and $\tau_{t}$ represent cohort and respectively period shifters, which capture cohorts heterogeneity and all the unobserved shocks that might affect permanent variance, transitory variance and earnings immobility by altering the slopes of the direct and indirect effects. 
The estimation results are included in Table 10.

\subsubsection{Specific 2-by-2 interactions between institutions, and between institutions and shocks}

This section attempts to open the black box of the systemic interactions investigated in the previous section and explore the specific interactions between institutions, and between institutions and shocks, which are expected to shape the pattern of permanent inequality, transitory inequality and earnings mobility. We start with a relatively simple model in which we explore the direct effect of institutions, shocks and the interactions between shocks and institutions. Moreover, we allow the effects to differ by cohorts to account for cohort heterogeneity. The model is expressed as follows:

$$
y_{i t}=\delta_{c}\left[\sum_{k=1}^{K} v_{k} X_{k i t}+\sum_{s=1}^{S} \psi_{s}\left(Z_{s i t}-\overline{Z_{s}}\right)\left(1+\left(\sum_{k=1}^{K} \gamma_{k}\left(X_{k i t}-\overline{X_{k}}\right)\right)\right]+\mu_{i}+v_{i t}\right.
$$

where $\sum_{s=1}^{S} \psi_{s}\left(Z_{s i t}-\overline{Z_{s}}\right)$ is a set of observed macroeconomic shocks expressed in deviation from their mean, which are interacted with policy and institutional factors. $\delta_{c}, v_{k}, \psi_{s}$ and $\gamma_{k}$ are estimated simultaneously. As before $\delta_{c}$ represent the cohort shifters, normalized to 1 for the oldest cohort for identification, $v_{k}$ represents the direct effect of institution $X_{k}$ when the other intuitions and shocks are at their sample means, $\psi_{s}$ captures the direct effects of shocks and $\gamma_{k}$ capture the interaction effects between institution $X_{k}$ and the aggregate effects of macroeconomic shocks. The estimation results are presented in Model 2, Table 11.

The final model augments model (13) by adding also the 2-by-2 interaction effects between institutions and policies. Moreover, additional controls are added, which are aimed to control for educational structure (proportions of university and upper-secondary graduates), for sector structure (proportion of private employees), for the structure of the type of contract (proportion of employees with a permanent contract), for the structure of employment status (proportion of unemployed) and for occupational structure, by cohort. The estimation results are presented in Model 3, Table 11. 
One note needs to be made. $\mu_{i}$ captures the unobserved unit-specific heterogeneity, in our case cohort-specific heterogeneity. One might argue that our model suffers from unobserved heterogeneity bias. We tested for unobserved heterogeneity for each model, by cohort, using the Breusch and Pagan Lagrangian multiplier test for random effects. The test rejected the presence of unit-specific effects at $5 \%$ level of confidence.

Another problem is the endogeneity between institutions and overall inequality that is expected to be transferred to the estimation of the two inequality components. The lack of good instruments prevented us from correcting for this problem. Hence, our estimates reflect the complex associations that exist within the institutional framework, and between the institutional framework and the macroeconomic shocks, and not causal relationships.

\section{RESULTS - DESCRIPTIVE}

\subsection{The dynamic autocovariance structure of hourly earnings}

We begin with the description of the dynamic structure of individual log hourly earnings for all 14 countries under analysis. This description is used to confirm that the model used to fit the autocovariance structure of earnings for all cohorts is consistent with the trends observed in the dynamic autocovariance structure. For a full description of the overall and cohort autocovariance structure of earnings please refer to Sologon and O'Donoghue (2009b, 2009a, 2009c). The overall autocovariance structure of earnings is presented in Figure 2. We summarize the main findings as follows.

In the beginning of the sample period, the overall inequality, measured by the variance of $\log$ hourly earnings, is the highest in Portugal, followed by Ireland, Spain, France, Luxembourg, UK, Greece, Germany, Austria, Italy, Belgium, Netherlands, Finland and Denmark. Overall inequality decreases over the sample period in Germany, Denmark, Belgium, France, UK, Ireland, Spain and Austria, and increases in Netherlands, Luxembourg, Greece, Portugal and Finland. Following these changes, in 2001, Portugal still records the highest inequality, followed by Luxembourg, France, Greece, Spain, UK, Italy, Germany, Ireland, Netherlands, Finland, Belgium, Austria and Denmark. 
In summary, the description of the dynamic structure of individual earnings for men for each country suggests five main common features of the data, which are incorporated in our model, as mentioned previously:

- First, the covariance elements are not the same at all lags. They decrease with the lag at a decreasing rate and converge gradually at a positive level, suggesting the presence of a transitory element which is serially correlated and of a permanent individual component of earnings.

- Second, as the autocovariances and mean earnings vary over the sample period, they cannot be assumed to be stationary over sample period. The stationarity assumption was tested and rejected using the methodology introduced by MaCurdy (1982).

- Third, as the autocovariances vary with age controlling for the period effect, they cannot be assumed to be stationary over the life cycle.

- Lastly, the variance-covariance structure appears to be cohort specific. In most countries, the variance of earnings for all cohorts follows the evolution of the overall variance. Mixed trends across cohorts are observed in Germany - where the variance increased for the cohorts born in 1941-1950 and 1961-1970 -, in Belgium - where the variance increased for the youngest cohort -, in France - where the variance increased for the cohort born in 1961-1970 -, in UK - where the variance increased for the youngest two cohorts -, in Spain - where the variance increased for the youngest and the oldest cohorts, and in Finland - where the variance decreased for the youngest cohort.

\subsection{The evolution of the main labour market and institutional factors}

This section presents the evolution of the main labour market policy and institutional variables that will be used to explain the differences in labour market outcomes - permanent inequality, transitory inequality and earnings mobility - across the 14 EU countries.

The evolution of the labour market policy and institutional factors is summarized in Table 4 and Figure 3. Over the period 1994-2001, the OECD index of employment protection legislation decreased in most countries under analysis, except for Austria, France, Ireland and Greece, where it was constant and UK, where it increased slightly. Employment protection legislation (EPL) exhibited a sharp turnaround around 1995 in Denmark, 1996 in Portugal, 1997 in 
Belgium, Germany and Spain, 1999 in Netherlands, 2000 in Finland, which marked the year when EPL started decreasing. For Italy the decrease continued through the rest of the period, whereas for the others the evolution was roughly stable. An increase in EPL was recorded in Spain in 2001 and in Ireland in 2000.

Employment protection legislation for regular contracts (EPLR) did not change much, except for Spain and Finland, where it decreased in 1997, respectively in 2001, and France and UK, where it increased in 2000, respectively in 1999.

The greatest changes were recorded for employment protection legislation for temporary contracts (EPLT). A decrease was recorded in Denmark, Portugal, Germany, Belgium, Italy and Netherland, and an increase in Spain. The rest remained constant. Denmark recorded a sharp drop in 1995, Belgium and Germany in 1997, Italy in 1997-1998, Portugal in 1996, Netherlands in 1998.

As a result, over the sample period, an increasing or stagnant positive relative difference between EPL for permanent contracts and for temporary contracts was recorded in Austria, Ireland, Netherlands, Portugal, UK and Finland. Denmark, Germany and Netherlands recorded a sharp increase in the relative difference between EPL for permanent contracts and for temporary contracts, which turned from a negative value in 1994 to a positive one in 2001. Belgium, France, Italy, Spain and Greece exhibited a negative relative difference between EPL for permanent contracts (EPLP) and for temporary contracts (EPLT), which, over the sample period, decreased or remained constant in absolute value, except for Spain.

A decrease in union density is reported in all countries, except Belgium. The degree of corporatism was characterized by stable rates in all countries. The tax wedge exhibited a high turnaround in 1995 for all countries, except the continental ones. The largest decline was in the Anglo-Saxon countries, followed by Nordic and Mediterranean countries. Exceptions are Austria, Belgium, Denmark and France, where the tax wedge increased. The index of product market regulation (PMR) declined through the entire period, but the rate of decrease intensified after 1998 for most countries. Unemployment benefits replacement rates rose in all countries, except Denmark, Finland and UK. Sharp increases were recorded around 1998-1999 in Italy and Portugal, and around 2000-2001 in France and Ireland. Active labour market policies (ALMP) 
developed in all countries, except Germany, where they decreased. The largest increases were recorded in Netherlands, Denmark and Ireland.

The possible static effects of these policies are raising employment and reducing productivity, whereas the possible dynamic effects are raising investment following the raise in employment and raising incentives for adoption of new technologies, which implies a shift in the demand for skills. (Dew-Becker and Gordon 2008) Hence all these are expected to influence permanent earnings inequality and volatility and earnings mobility.

Nevertheless, institutional factors do not exist in a vacuum. They are expected to interact with external factors, such as macroeconomic shocks. The evolution of the macroeconomic shocks illustrated in Figure 4. Changes in demand and supply factors, in technology, in terms of trade, in real interest do not differ significantly among countries; hence they cannot by themselves explain all the changes in the inequality components. These trends are not surprising, given that all these countries operate in the same world markets, with similar technology, industry and occupation mixes.

For example, all countries experience the same turning points in both demand and supply shocks. The supply shocks had three turning points: a decrease until 1996, followed by a decrease until 1998, an increase until 2000, and a drop thereafter. The supply shocks converged in a decreasing trend for all countries towards 1999 , followed by an increase in 2000 , and a slight decrease in 2001. The convergence in the trends was maintained until 2001. Overall, the highest demand and supply shocks are experienced by Ireland, followed by Belgium, Austria and Netherlands. One country stands out with respect to its evolution in total production factors shock: Ireland. It records a sharp increase until 1997, followed by stabilization towards 2001. Similarly, the real interest shock drops towards 1998 and stabilizes afterwards. These trends are most likely related to the Celtic Tiger.

The OECD data on education attainment by country reveals that the average level of education has an increasing trend and evolves parallel for all countries. Three clusters can be identified. A high average level is achieved in Germany, followed by Finland, Denmark, then very closely Ireland, UK and Belgium. A medium level is recorded in Greece, Austria, France, Spain and Italy. The lowest level is in Portugal. 
To sum up, labour market policy and institutional factors are expected to interact significantly with each other and with the macroeconomic shocks in shaping the patterns of permanent inequality, transitory inequality and earnings mobility.

\section{ReSults of COVARIANCE StRUCTURE Estimation}

\subsection{Estimation results}

The general specification of the error component model outlined in section 4.1.2, which encompasses all relevant aspects of earnings dynamics considered above, is fit to the elements of the covariance matrix of each country, for all cohorts pooled together ${ }^{12}$. We present only the models that fit the data the best for each country, as identified by Sologon and O'Donoghue (2009b, 2009a, 2009c). The estimation results are illustrated in Table 6. Similar to Dickens (2000), all variances are restricted to be positive by estimating the variance equal to the exponent of the parameter. The reported estimates of the variance in Table 6 represent the exponent of the parameter and the reported standard errors correspond to the parameter estimates. ${ }^{13}$

We summarize the interpretation from Sologon and O'Donoghue (2009b, 2009a, 2009c). The formulation of the permanent and transitory components of earnings differs between countries.

\section{Permanent component}

In Germany, Netherlands, UK, Ireland, Italy, Greece, Spain and Finland, the permanent component follows a random growth model with time and cohort specific loading factors. The estimated coefficients for the permanent component of earnings show that time-invariant heterogeneity and age-earning profile heterogeneity play a significant role in the formation of long-term earnings differentials in all these countries. Individual specific heterogeneity plays the highest role in Germany, followed by Spain, Netherlands, Greece, UK, Ireland and Italy, which suggests that in Germany there is a higher dispersion in the time-invariant individual specific attributes that determine wage differentials.

\footnotetext{
${ }^{12}$ i.e. 144 auto-covariances for countries observed over 8 waves, 122 for those with 7 waves and 84 for those with 6 waves.

${ }^{13}$ The SE column reports the standard error for the parameter estimate. Where I report the $\exp ($ estimate $)$, the SE corresponds to the $\log (\exp (\operatorname{estimate}))=$ estimate
} 
The estimated random slope variance implies that hourly earnings growth for an individual located one standard deviation above the mean in the distribution of $\varphi$ is the largest in Germany, where it is with $4.89 \%^{14}$ faster than the cohort mean, followed by Greece, Ireland, Spain, Netherlands, UK and Finland with rates between $1 \%$ and $1.41 \%$ and Italy with $0.89 \%$. All these countries have a negative covariance between the time invariant individual specific effect and the individual specific slope of the age-earning profile, which implies that the initial and lifecycle heterogeneity are negatively associated. This negative association corresponds to the trade-off between earnings early in the career and subsequent earnings growth and is consistent with the on-the-job training hypothesis (Mincer, 1974). Therefore, this suggests the presence of mobility within the distribution of permanent earnings over the sample period. These findings reinforce the results from previous studies.

Therefore, for these countries the evolution of the permanent component without the time loading factors could be either increasing or decreasing. The time-specific loading factors for the permanent component are highly significant with values close to 1 in all countries. The trends of the returns to the permanent component vary to a large extent across countries. One common feature is that they reflect the trends in the high-order autocovariances in the data. These estimates show that overall, controlling for age and cohort effects, the returns to skills decreased over the sample period in Netherlands, UK, Ireland, Italy, Greece, Spain and increased in Germany and Finland. The trends over time differ between countries, some record a smooth evolution, others noisier. For example, Netherlands experienced decreases in returns almost every second year. In UK the returns increased in 1997 and 2001, and decreased in the rest. Ireland recorded a decrease until 1996, a boost in 1997 and a clear decline thereafter. In Italy, 1998 and 1999 appear to be years with increases in the return to skills, in Greece every second year, in Spain 1995 and 1998. Germany experienced increasing returns to human capital until 2000, and Finland in 1997 and 2001. Therefore, in these years, the relative position of the highly skilled individuals was enhanced.

In Denmark the permanent component follows a random walk in age. The variance of the innovation in the random walk is significantly larger than zero. As the variance of a variable that follows a random walk is the sum of the variances of the innovation term, this finding implies

${ }_{14} 4.89=100 \cdot \sqrt{\sigma_{\varphi}^{2}}$ 
that permanent inequality increases over lifetime. In Denmark, the variance at the age of 20 is lower than the variance at subsequent ages, suggesting the presence of larger permanent shocks at older ages, which is consistent with matching models, in which the information revealed about a worker's ability increases with time. The final trend in the permanent variance depends on the period specific loading factors, which reveal that overall, the relative position of the highly skilled individuals decreased over the sample period in Denmark. The yearly evolution revealed a smooth decrease until 2000, followed by a small increase in 2001.

In Belgium, France, Luxembourg, Portugal and Austria the persistent dispersion of earnings follows the canonical model, where the permanent component is time-invariant. The highest variance in the time invariant characteristics is recorded in Portugal, followed by France, Luxembourg, Austria and Belgium. In this case, the time-specific loading factors determine the final trend of the permanent differentials: they decreased in Belgium and Austria, and increased in France, Luxembourg and Portugal. Year by year, France records an increase in the returns to skills until 1997 and again in 2001, Luxembourg until 2000, Belgium in 1996 and 2000, Austria during most of the period, except 1998-1999, and Portugal in 1996, 1998 and 2000.

The estimates of the cohort-specific shifters for the permanent earnings are highly significant in all countries. The trends, however, differ between countries. A monotonic increase over the lifecycle is observed in Germany, France, Luxembourg, Portugal and Austria. In Denmark, Netherlands, Belgium and Spain the permanent component of earnings has an inverted-U shape evolution over the lifecycle. These trends confirm the expectation that permanent earnings differentials play a much larger role in the formation of overall earnings differentials of older cohorts compared with younger ones, which experience higher earnings volatility due to temporary contracts. We expect the opposite to hold in the case of cohort-specific shifters for transitory earnings.

The permanent component of earnings decreases over the life cycle in UK, Ireland, Italy, Greece and Finland. This may be due to younger cohorts having more heterogeneous skills or experiencing larger permanent shocks even without a larger dispersion of skills. This could be the case if the labour market has become tougher over time, as in the case of the Italian case, which is characterised by high rates of youth unemployment. 


\section{Temporary component}

The formulation of the temporary component of earnings differs between countries. It follows an $\mathrm{AR}(1)$ process with time and cohorts loading factors in all countries, except Italy, Greece and Spain, where it follows an $\operatorname{ARMA}(1,1)$. Except for Spain, Portugal and Austria, the other countries are characterized by heteroskedastic initial conditions. The estimated coefficients for the transitory component of earnings are all significant, suggesting that the initial variance(s), the $\operatorname{AR}(1)$ process, the $\operatorname{ARMA}(1,1)$ process, and the time and cohort loading factors contribute significantly to earnings volatility in all countries.

The variance of initial conditions, which represents the accumulation of shocks up to the starting year of the panel, is smaller than the variance of subsequent shocks in all countries, except Luxembourg, Ireland, the oldest three cohorts in UK, and the middle two cohorts in Finland. Overall, the variance of initial conditions increases over the lifecycle in Denmark, Belgium, France, Luxembourg, UK, Italy, Greece and Finland, suggesting that the initial variance plays a larger role in the formation of earnings differentials for the oldest cohort compared with the youngest. The opposite is observed in Germany, Netherlands and Ireland.

The pattern of the heteroskedstic initial conditions, however, is not monotonic across cohorts. In Luxembourg, UK, Italy, and Finland it follows an inverted-U shape: the variance of initial conditions increases over the lifecycle and decreases at the end. The opposite holds for France, where the oldest and the youngest cohorts have the highest initial variances.

In Germany and Netherlands the pattern of the heteroskedstic initial conditions records a sharp drop for the second youngest cohort, an increase for the second oldest and a small drop for the oldest cohort. In Denmark, Belgium, Ireland and Greece, the variance of initial conditions records an increase for the second youngest cohort, a drop for the second oldest and an increase for the oldest cohort.

The magnitude of the autoregressive parameter varies between countries. A large autoregressive parameter, which suggests that shocks are persistent, is recorded in Spain with $26.9 \%$ of a shock still present after 8 years, in Portugal with $8.5 \%$ and in Austria with 5.7\%. A moderate autoregressive parameter suggesting that shocks die out rather quickly is recorded in Italy with $2.8 \%$ of a shock still present after 8 years, in Belgium with $2.4 \%$, and in Greece with $1.4 \%$. A small autoregressive parameter is present in Luxembourg, Ireland, Finland, Netherlands, 
Germany, France, UK and Denmark, where between $0.0008 \%$ and $0.8 \%$ of a shock is still present after 8 years. The negative sign of the MA component implies that the autocovariances decline sharply over the first period, confirming the trends observed in the previous section for Italy, Greece and Spain ${ }^{15}$

The time-specific loading factors for the transitory component are highly significant and display a higher variation than for the permanent component in all countries. The trends of the transitory inequality vary to a large extent across countries. These estimates show that overall the transitory variance decreased over the sample period in all countries, except Luxembourg and Ireland.

The estimates of the cohort-specific shifters for the transitory earnings are highly significant in all countries. They indicate that earnings volatility is higher for younger cohorts, thus confirming the pattern observed in the dynamic description of the autocovariance structure of earnings, where autocovariances were found to be lower for younger cohorts. This is expected, given that younger people experience in general more frequent job changes, and consequently less stable earnings.

\subsection{Inequality Decomposition into Permanent and Transitory Inequality}

Having estimated a suitable error component model for earnings in each country, next we use these parameters estimates to decompose the variance-covariance structure of earnings into its permanent and transitory components, assess their relative importance, and estimate earnings immobility over the sample period, by cohort.

Following Sologon and O'Donoghue (2009b, 2009a, 2009c), Figure 5 illustrates the absolute decomposition of the variance, together with the actual and predicted variance of earnings by cohort. The decomposition by cohort identifies how inequality and its components are affected by labour market changes at different lifecycle stages. For all countries, the evolution of the predicted variance follows closely the evolution of the actual variance, confirming the fit of the country models, indicated by the low sum of square residuals. Figure 7 illustrates the evolution of the structure of inequality, expressed by the relative decomposition of the overall predicted variance of earnings into its permanent and transitory components. Figure 8 translates these trends into earnings immobility, measured by the ratio between permanent and transitory

\footnotetext{
${ }^{15}$ For the other countries, the MA component was either rejected by the data or could not be identified due to the low number of waves.
} 
differentials. An increase in the immobility ratio indicates a decrease in mobility, equivalent to an increase in the share of the permanent differentials in the overall inequality. This mobility index captures non-directional earnings movements and can be interpreted as the opportunity to improve one's position in the distribution of lifetime earnings.

The trends by cohort illustrated in Figure 5, Figure 7, and Figure 8, for the actual earnings inequality, permanent inequality, transitory inequality, the share of the permanent inequality in the overall inequality and the immobility ratio are described in Table 7. The trends in average actual inequality, average components and average immobility ratio ${ }^{16}$ across cohorts are described in Table 8. We underline only the key points. For a complete description, please refer to Table 7, Table 8 and Sologon and O'Donoghue (2009b, 2009a, 2009c).

For all countries, both in relative and absolute terms (Figure 5 and Figure 7), individual earnings inequality contains a highly permanent component for the oldest three cohorts and a highly transitory component for the youngest cohort. This is consistent with the evidence of lifecycle earnings divergence showing that earnings volatility is higher at younger ages. The degree of immobility (Figure 8) is higher for older cohorts compared with younger cohorts, which suggests that the older the cohort, the lower the opportunity to improve one's position in the distribution of lifetime earnings.

The overall trends are established by looking at averages across cohorts (Table 8). Overall, the decrease in inequality resulted from a decrease in transitory differentials in Germany, France, UK and Ireland, in permanent differentials in Belgium and Spain, and in both components in Denmark and Austria. The increase in inequality reflects an increase in permanent differentials in Luxembourg, Italy, Greece and Finland, and an increase in both components in Portugal and Netherlands.

The decrease in inequality was accompanied by an increase in mobility only in Denmark, Belgium and Spain. Except for Netherlands and Portugal, all countries recording an increase in inequality experienced also a decrease in mobility.

More important are the welfare implications of these trends. In Denmark, Belgium and Spain, in 2001 , low wage individuals are better off both in terms of their relative wage and in terms of the

\footnotetext{
${ }^{16}$ Average Immobility Ratio $=$ Average Permanent Variance/Average Transitory Variance
} 
opportunities to escape the low-wage trap in a lifetime perspective. Thus in a lifetime perspective, Denmark, Belgium and Spain are expected to reduce lifetime earnings differentials compared with annual differentials. In Austria, Germany, France, UK and Ireland, in 2001, lowwage individuals are worse off in terms of the opportunity to escape the low-wage trap, but their relative position in the earnings distribution is improved compared with the 1st wave. For these countries mobility is expected to play a decreasing role in reducing lifetime inequality, therefore annual differentials have a high chance of being preserved in a lifetime perspective.

In Luxembourg, Italy, Greece, and Finland, besides the widening wages differentials, low wage individuals find it harder to better their position in the wage distribution in 2001 compared with the first wave. Thus we can expect these countries to increase lifetime earnings differentials compared with annual differentials. Netherlands and Portugal record widening wages differentials accompanied by increased opportunity of low wage individuals to improve their position in the distribution of lifetime earnings. Thus, for Netherlands and Portugal, earnings mobility could either decrease or exacerbate lifetime earnings differentials compared with annual ones.

The evolution of the actual inequality, permanent inequality transitory inequality, and the immobility ratio differ from the general trend across cohorts in a few countries, suggesting that the reforms influenced differently older from younger workers. (see Table 7, Figure 5, Figure 7, Figure 8)

These trends in the structure of inequality and immobility, however, were not monotonic, as can be observed in Figure 7 and Figure 8. For Denmark and Spain, a turnaround is observed around 1998-1999, when the share of the permanent component and earnings immobility started decreasing, following the increase over the period 1994-1998. For Denmark, 1998 was a year which marked the end of a period of continuous economic growth which began in 1993. (EIROnline) In Spain, 1999 marked the year of the approval of the National Action Plan and of the reform of the Spanish legislation on temporary employment agencies, which improved the pay for temporary workers. (EIROnline) In Belgium, the adoption of the NAP took place around 1999-2000. (EIROnline).

In France, a significant change occurred after 1996, when the share of the permanent component and earnings immobility started to decrease. This might be explained by the rapid increase in 
employment which occurred in France between 1997 and 2002 as a result of the policies aimed to lower the cost of unskilled jobs and stimulate job creation.

In Ireland, the significant turnaround in 1997 might be due to the slowing down of the Celtic Tiger: the remarkable economic growth which started in 1994 was accompanied by a rise in the share of permanent inequality and earnings immobility, which contracted slightly after 1997. Hence, the economic growth was a shock that accentuated the share of permanent differentials in the overall inequality and increased earnings immobility between 1994 and 1997. After 1997, the trends reversed.

A dramatic change occurred in Austria after 1998. Until 1998, wage immobility and the share of permanent inequality increased sharply. In 1999, Austria experienced a considerable rise in employment and a further decline in unemployment, which was the effect of the labour market initiatives pursued by the Austrian Government. This explains the increase in inequality after 1999: higher employment is usually accompanied by higher inequality. These measures appear to have decreased earnings immobility and the share of permanent inequality in 1999, which stabilized thereafter.

In Netherlands, a significant changed occurred after 1998, when immobility and the share of permanent inequality started decreasing, offsetting the increasing trend which dominated the period before 1998. Among the important issued addressed by the labour market legislation in 1998 were part-time employment, labour market flexibility and active labour market policies. In 2001, the share of the permanent components was the lowest among all countries which recorded an increase in overall inequality.

For Luxembourg, Italy, Portugal, Greece and Finland, a turning point occurred around 19981999. This period coincides with the approval of the National Action plan for employment aimed, among others, to lower labour cost, promote active labour market policies, training and increase labour market flexibility. This appears to have affected the structure of wage differentials to a large extent. Immediately after 1998-1999, the share of permanent inequality and wage immobility started to decrease.

Following Sologon and O'Donoghue (2009b, 2009a, 2009c), Figure 9 summarizes the country ranking with respect to earnings persistency and earnings immobility over the sample period, by cohort. The higher the share of permanent inequality, the higher the immobility. In the first 
wave, for the oldest cohort, the highest share of the permanent component (the lowest mobility) is in Germany (97\%), followed by Portugal, Spain, Netherlands, Italy, Ireland, Denmark, France and UK with shares between $85 \%$ and $60 \%$, and the rest with shares between $60 \%$ and $49 \%$. For the cohort 1951-1960, the highest permanent share (the lowest mobility) is in Portugal (89\%), followed by Spain, Germany, Ireland, Netherlands, Belgium, UK, Italy, Denmark and France with shares between $78 \%$ and $60 \%$, and the rest with shares between $58 \%$ (Greece) and $47 \%$ (Finland).

For the 1961-1970 cohort, the highest permanent shares (the lowest mobility) are in Netherlands and Portugal (77\%), followed by Spain, France and Germany - with shares between $68 \%$ and 64\% -, Luxembourg, UK, Belgium, Austria and Ireland - with shares between 56\% and 42\% -, and the rest with shares between 40\% (Denmark) and 21\% (Greece). For the cohort 1971-1981, the highest permanent share is recorded in UK (52\%), followed by Luxembourg (45\%), Greece, Finland, Ireland, Portugal, Italy and Spain - with shares between $38 \%$ and $25 \%$-, and the rest with shares between $18 \%$ (Netherlands) and 2\% (Belgium).

Following these changes, the structure of inequality and earnings immobility in 2001, for the oldest cohort, the highest share of permanent inequality implying the highest earning persistency (lowest mobility) is found in Luxembourg, France, Germany, Italy, Ireland, Portugal and Spain, with rates between $82 \%$ and $73 \%$. Greece, Netherlands, Finland, UK and Austria are less persistent with values between $70 \%$ and $60 \%$. The least persistent - most mobile - are Denmark and Belgium, where permanent variance accounts for $56-58 \%$ of the overall variance.

For the 1951-1960 cohort, the highest persistency - lowest mobility - is recorded by the same countries, including UK and Finland, with shares between $85 \%$ and $71 \%$, followed by Greece, Austria and Netherlands with shares between $68 \%$ and $61 \%$, and lastly Belgium (56\%) and Denmark (49\%). For the 1961-1970 cohort in Luxembourg, Ireland and Finland permanent variance accounts for $79 \%$ to $70 \%$ of the overall variance, followed by UK, France, Germany, Italy and Portugal with shares between $66 \%$ and 63\%, by Spain, Greece and Austria with shares between $58 \%$ and $56 \%$, and by Belgium, Netherlands and Denmark with shares between $45 \%$ and $42 \%$.

For the youngest cohort, the variance is dominantly transitory in all countries, except Ireland where the transitory variance accounts for $46 \%$ of the overall variance, suggesting that Irish 
youngsters have the lowest degree of earnings mobility in Europe. The most volatile earnings are found in Belgium, where $98.5 \%$ of the variance is transitory. Next follow Denmark and Netherlands where transitory variance accounts for $89 \%$ of the overall variance; Spain, Austria and Portugal, with transitory shares between $84 \%$ and $81 \%$; Germany, France, Finland, Italy and UK with transitory shares between $72 \%$ and 63\%; Greece and Luxembourg where transitory inequality accounts for $56 \%$ of the variance.

Based on Sologon and O'Donoghue (2009b, 2009a, 2009c), we summarize the changes in country ranking in permanent inequality, transitory inequality, and earnings immobility over the sample period by reporting the averages across cohorts. In 1994, the highest average permanent inequality ${ }^{17}$ was recorded in Portugal and Spain, followed by France, Ireland, Germany, UK, Greece, Italy, Netherlands, Belgium and Denmark. The highest transitory variance was recorded in France, Ireland, Greece, UK, Germany, Spain, Belgium, Denmark, Netherlands, Italy and Portugal. Portugal has the lowest mobility, followed by Spain, Germany, UK, Italy, Ireland, Netherlands, France, Belgium, Greece and Denmark. In 1995, Austria and Luxembourg had a middle ranking in permanent inequality and a top ranking ${ }^{18}$ in transitory inequality and mobility. In 1996, Finland had the second lowest permanent inequality, a middle ranking in transitory inequality, and the highest mobility.

In 2001 the rankings looks slightly different. Portugal records the highest average permanent differentials, followed by Luxembourg, France, Spain, Ireland, Germany, Greece, UK, Italy, Finland, Netherlands, Austria, Belgium and Denmark. In terms of transitory inequality, Portugal appears to be the most dispersed, followed by Spain, Netherlands, France, Greece, UK, Germany, Belgium, Luxembourg, Austria, Ireland, Denmark, Finland and Italy. Denmark has the highest average earnings mobility, followed by Belgium, Netherlands, Austria, Spain, Greece, Finland, UK, France, Germany, Italy, Portugal, Ireland and Luxembourg.

\section{Linking Policy With OUTCOMES}

What are the factors explaining country heterogeneity in the level and the evolution of permanent differentials, transitory differentials and earnings mobility? We try to explain the cross-country differences in these labour market outcomes by relating to the differences in the wage setting

\footnotetext{
${ }_{17}^{17}$ Average permanent variance and transitory variance represent average across cohorts.

${ }^{18}$ Among the highest four.
} 
mechanism and the other labour marker institutions and policies - such as active labour market policies and income maintenance institutions (e.g. unemployment benefits) -, and the institutional and policy changes - such as employment protection legislation, product market regulation, tax wedge, unionization.

First we describe with the naked eye the possible associations that can be formed between the trends in the labour market outcomes identified in the previous section and the changes in the labour market policy and institutional factors identified in Section 5.2 and summarized in Figure 3. Second, by cohorts, we estimate uncontrolled pairwise correlations to put some numbers on the observed trends and see whether the relationships differ by cohorts- Finally, using non-linear least squares, we estimate the complex relationship between the institutional factors and permanent inequality, transitory inequality and earnings immobility.

\subsection{Explaining the changes and differences}

We start with the rankings in average permanent and transitory differentials and average mobility observed in 1994 and 2001 (see Section 6.2). At a first glance, the diverging characteristics of the labour markets (see Figure 3) recording the highest and the lowest average permanent differentials - Portugal and Denmark -, suggest that permanent variance appears to be positively associated with employment protection legislation (EPL), employment protection legislation for regular contracts (EPLR), employment protection legislation for temporary contracts (EPLT), the relative difference between the EPLR and EPLT, and product market regulation (PMR), and negatively associated with union density, the degree of corporatism, the tax wedge, the generosity of the unemployment benefit and the level of spending for active labour market policies (ALMPs).

Similarly, temporary variance appears to be positively associated with EPLT, the unemployment benefit generosity, and negatively with union density, PMR and the degree of corporatism.

Looking at the labour markets with the highest and lowest average immobility in 1994 and 2001 (Section 6.2), a positive association was found with the union density, the tax wedge and the unemployment benefit replacement rate, and a negative association with EPLR, the relative difference between EPLR and EPLT, and PMR. For the other factors the trend is less clear-cut. 
Next, we try to link the evolution of the three labour market outcomes with the evolution of the institutional factors summarized in Figure 3.

The common factors that might explain the common trends in permanent differentials and mobility in Denmark, Belgium and Spain are the decrease in EPL, the increase in ALMP and the decrease in PMR. ALMP can reduce permanent and transitory differentials by improving the efficiency of the job matching process and by enhancing the skills of the unemployed. Moreover its effects are expected to be enhanced when they are coupled with a low or decreasing EPL. Denmark represents a proof of the efficiency of this mix in reducing both components.

The ALMP-EPL mix might also be one of the factors explaining the divergence in the transitory variance trends between these countries: Denmark exhibits a high ALMP coupled with a low EPL, whereas the other two exhibit a relatively low ALMP coupled with a medium high EPL. This suggests that the impact of ALMP on transitory inequality might decrease with the EPL. A second factor could be the interaction between the decrease in PMR and the other factors. Lower PMRs are expected to determine an increase in both components. However, these effects appear to be completely offset in Denmark, whereas in Belgium and Spain they are offset only for permanent differentials.

Third, the decrease in transitory variance in Denmark might signal the presence of strong wage bargaining structures, finding supported by the high union density, corporatism and bargaining coverage indicators. This is consistent with the OECD (2004) results, which placed Denmark as having one of the highest collective bargaining and trade union density among all 14 EU countries under analysis. In Belgium and Spain, another potential factor explaining the increase in transitory inequality might be immigration, which increased considerably with the expansion of the European Union.

To sum up, the outstanding performance of the labour market in Denmark which assured a decreasing cross-sectional inequality by reducing both components, might be due to the so called “flexicurity approach" (OECD(2004)), which represents an interesting combination of high labour market dynamism and relatively high social protection. It is a mix of flexibility (a high degree of job mobility thanks to low EPL), social security (a generous system of unemployment benefits) and active labour market programmes, which allows individuals to improve their 
position in the permanent income distribution by reducing permanent income differentials, maintain at the same time a low degree of earnings volatility.

The common factors that might explain the decrease in transitory differentials and the decrease in mobility in Germany, France, UK, Ireland and Austria are the decrease in union density and PMR, the increase in ALMP and the low EPL which was roughly constant, except for Germany where the latter two factors decreased. The decrease in union density and PMR are potential factors explaining the increase in permanent differentials in Germany, France, UK and Ireland, which appear to have offset the effect of the increase in ALMP present in the latter three countries. UK, Ireland and Austria exhibit another factor with a potential increasing effect on permanent differentials: the decrease in the tax wedge.

The decrease in transitory variance, which is common to all these countries, reinforces the finding that developed increasing ALMP coupled with a relatively low EPL can be expected to dampen earnings volatility. Hence, for transitory differentials, the impact of the ALMP-EPL mix appears to have offset the potential effects of the decrease in union density and PMR. Moreover, the dampening effect of the ALMP-EPL mix on the transitory inequality appears to be accentuated when it is coupled with an increase in the unemployment benefit generosity. It is the case in France, Ireland and Austria.

In France, other factors which might contribute to the absolute increase in the permanent component are the increase in EPLR, because of the potential reducing effect on the incidence of permanent contracts. The decrease in transitory inequality might also signal a labour market mechanism put in place to reduce transitory inequality. This is consistent with OECD (2004): France ranks the lowest on union density, but managed to increase coverage levels after the introduction of the legislation promoting collective bargaining and is now among the countries with the highest coverage rates of $90 \%$ and above, together with Austria, Belgium and Finland. Moreover, based on OECD (2004), France was found to have a low level of labour market dynamics, which might explain the reduction in transitory inequality and mobility.

In UK, the positive increasing relative difference between EPLR and EPLT, coupled with the low degree of corporatism could have accentuated the disincentive for employers to train temporary workers, and thus could have contribute to increase permanent differentials. 
In Luxembourg, Italy, Greece, Finland, and Portugal the common institutional trends that might explain the increase in permanent differentials are the decrease or constant evolution of the EPL, the decrease in union density, PMR and the tax wedge. Italy and Portugal exhibit also a decrease in EPLT relative to EPLR, which might accentuate permanent differentials. The decrease in transitory differentials and the increase in immobility in Luxembourg, Italy, Greece, and Finland might be explained by the increase in the ALMPs, coupled with the increase in the generosity of the unemployment benefit, except for Finland. The increase in transitory differentials recorded by Portugal might be due to the level of corporatism: an intermediate level appears to accentuate transitory differentials, whereas a high level might help to reduce them.

\subsection{Correlations}

Given the clear distinction in the trends of the two components and earnings immobility between the oldest three cohort and the youngest cohorts, we expect also the underlying factors to differ to a certain extent. Thus, it is necessary to account for cohort heterogeneity when analysing the link between the three labour market outcomes and the institutional and policy factors. As a first step, we estimate the simple uncontrolled correlations (Table 9) comparatively between the oldest there cohorts, polled together, and the youngest one.

Permanent variance for the older cohorts is significantly ${ }^{19}$ positively associated with all the EPL factors and PMR, and significantly negatively associated with union density, the degree of corporatism, the tax wedge, the ALMPs, and the unemployment replacement rate. Discrepancies between cohorts with respect to permanent variance are recorded for the EPL factors, which are negatively associated, and PMR which is insignificant. For the other factors the associations are consistent across cohorts ${ }^{20}$.

Transitory variance for the older cohorts is significantly ${ }^{21}$ positively associated with the EPL, EPLR and EPLT, and significantly negatively associated with the rest, except the relative difference between EPLR and EPLT and PMR which are insignificant. The youngest cohort records fewer significant associations: a positive association ${ }^{22}$ is recorded with EPL, EPLR and

\footnotetext{
${ }^{19}$ At $1 \%$ and $5 \%$ level of confidence

${ }^{20}$ The associations for the youngest cohorts are significant at 1\%,5\% and $10 \%$ level of confidence.

${ }^{21}$ At $1 \%$ evel of confidence

${ }^{22}$ Significant at $5 \%$ and $10 \%$ level of confidence
} 
the unemployment replacement rate, and a negative association ${ }^{23}$ with union density and the degree of corporatism.

The immobility ratio for the oldest three cohorts exhibits a positive significant association with EPL, EPLR and PMR, and a significant negative association with union density ${ }^{24}$ and the unemployment benefit replacement rate $^{25}$. For the youngest cohort, the immobility ratio is significantly positively associated with the relative difference between EPLR and EPLT, and significantly negatively ${ }^{26}$ associated with the other factors except the union density and PMR, which are insignificant.

The trend differences in permanent inequality, transitory inequality and immobility observed between cohorts Figure 5, Figure 8, and Table 7) might be related also with the different levels of responsiveness to the macroeconomic shocks and their interactions with the other labour market policy and institutional factors. Younger workers are expected to be affected to a larger extent by these shocks, compared with experienced workers, which have a high attachment to the labour market and a better protection from the institutional framework. This might explain the much higher share of transitory inequality observed for younger cohorts.

The correlations with the macroeconomic shocks (Table 9) reveal differences between cohorts. For permanent variance, the youngest cohort records a much stronger positive correlation with labour demand shocks compared with the oldest cohorts, and insignificant correlations for the other shocks. For the oldest cohorts, the other shocks exhibit significant negative correlations, except the terms of trade shock. For transitory variance, only the total factor production and the aggregate demand shocks exhibit a significant negative association. Across cohorts, the negative association with the total factor production shock is stronger for the oldest cohorts. More differences between cohorts emerge for earnings immobility. For the oldest cohorts, a significant ${ }^{27}$ positive association is observed for the terms of trade shock. For the youngest

\footnotetext{
${ }^{23}$ Significant at $1 \%$ and $5 \%$ level of confidence

${ }^{24}$ At $1 \%$ level of confidence

${ }^{25}$ At $10 \%$ level of confidence

${ }^{26}$ At $1 \%, 5 \%$ and $10 \%$ levels of confidence

${ }^{27}$ At $10 \%$ level of confidence
} 
cohort, a significant ${ }^{28}$ positive association is observed for the labour demand shock, and a significant negative association ${ }^{29}$ with the real interest rate shock

Nevertheless, these correlations are far from telling the true story given the complexity of the interactions that take place between institutions on the one hand, and between institutions and macroeconomic shocks on the other hand.

To conclude, the institutional factors are expected to shape the pattern and the level of permanent inequality, transitory inequality and earnings immobility not only directly, but also in interaction with macroeconomic shocks. The overall institutional factors is expected to be a "filtering mechanism" for the adverse effect that these shocks might have on the three labour market outcomes, provided that their aim is to keep permanent and transitory inequality low, assuring at the same time that low wage individuals are not trapped in low pay, but have the opportunity to improve their position in the distribution of lifetime income through earnings mobility.

Moreover, we expect institutional factors to play a much larger role in shaping permanent differentials compared with transitory differentials and earnings immobility, given that the latter two are exposed to a much larger extent to random shocks, against which the institutional factors might have a delayed response or any at all.

\subsection{Estimation}

This section aims to provide some empirical evidence with respect to the impact of the main labour market policy and institutional factors and their complex interactions in shaping permanent inequality, transitory inequality and earnings immobility.

\subsubsection{Systemic interactions: do policies and institutions interact with the overall institutional framework?}

The results regarding systemic interactions are included in Model 1 in Table 10. The models with systemic interactions are estimated to explain $97.8 \%$ of the cross-country variation in permanent inequality, $93.2 \%$ of the cross-country variation in transitory inequality, and $71.6 \%$ of the crosscountry variation in earnings immobility, between 1994 and 2001.

\footnotetext{
${ }^{28}$ At $1 \%$ level of confidence

${ }^{29}$ At $5 \%$ level of confidence
} 
The cohorts shifters are highly significant in all models, confirming the cohort-heterogeneous trends identified previously by the error component model (Figure 6): the older the cohort, the higher the permanent variance and wage immobility, and the lower the transitory inequality.

Similarly, the time effects are highly significant in all models. They indicate that, overall, at the EU level, controlling for the effects of institutional and policy factors, the unobserved shocks had a decreasing impact on permanent variance in 1995, an increasing impact until 1997 and decreasing impact thereafter. The impact of the unobserved shocks on transitory inequality decreased until 2000 and increased in 2001. For wage immobility more variation is observed: it decreased in 1995, increased until 1997, decreased until 1999, increased again in 2000, followed by a drop in 2001. Overall, it appears that the unobserved shocks had a decreasing effect on both permanent and transitory dispersion, and an increasing effect on wage mobility.

The direct effects, controlling for the systemic interactions, cohort and the period effects, indicate that, except for product market regulation (PMR) and active labour market policies (ALMPs), all other factors have a significant impact on permanent dispersion. Factors that appear to reduce permanent inequality are the union density and the average unemployment benefit replacement rate. The hump shape profile of the impact of the degree of corporatism is confirmed: the intermediate level of corporatism appears to trigger the highest permanent dispersion, followed by a high and then a low corporatism.

The systemic interaction effects for union density, the degree of corporatism, the tax wedge and the PMR provide evidence of reform complementarity in reducing permanent inequality. Hence the more equality-friendly the overall labour market policy and institutional framework is, the greater is the reducing impact of a high union density, an intermediate and high degree of corporatism, a high tax wedge and a high PMR.

The model for transitory variance, despite having a similar level of explained variation as the model for permanent inequality, exhibits fewer significant effects for the institutional factors. The period effects and the cohort effects explain a large share of the variation in transitory inequality: random exogenous shocks increase earnings variability and the magnitude of their impact depends on the specific lifecycle stage a respective cohort is in.

Only the PMR, the ALMPs and the unemployment benefit replacement rate have a significant direct impact on transitory inequality. Ceteris paribus, an increase in the spending for ALMPs 
and in the unemployment benefit replacement rate increases transitory differentials, whereas an increase in the PMR reduces transitory differentials. Moreover, albeit insignificant, the higher the union density and the higher the degree of corporatism are, the larger is the reduction in transitory variance.

The systemic interactions suggest that there is a complementarity with the overall framework in reducing transitory inequality for the union density and the degree of corporatism. Hence, the more inclined the overall framework is towards reducing transitory differentials, the effect is larger the higher in the union density and the larger is the degree of corporatism. The effect of union density, however, is not significant at conventional levels. The other factors appear to counteract with the overall system, but the effect is significant only for the unemployment benefit replacement rate.

For earnings immobility, ceteris paribus, a significant positive direct effect is found for employment protection legislation (EPL), the relative difference between employment protection legislation for regular contracts (EPLR) and temporary contracts (EPLT), a high degree of corporatism and ALMPs. Similarly for PMR, but the effect is insignificant. A U-shaped profile is found for the degree of corporatism: a high degree of corporatism is found to increase wage immobility compared with low corporatism, whereas an intermediate corporatism appears to decrease it. Besides an intermediate corporatism, other factors that contribute directly to decrease earnings immobility are the union density and the unemployment benefit replacement rate.

The systemic interactions suggest that there is a complementarity with the overall framework in reducing wage immobility for the union density, and the degree of corporatism - with an stronger negative effect for the intermediate level than for a high level. The tax wedge also has a negative effect, but insignificant. PMR and ALMPs counteract with the overall framework, in a tendency to increase wage immobility.

\subsubsection{Specific Interactions}

This section explores the specific interactions between institutions, and between institutions and

observed macroeconomic shocks, expected to shape the pattern of permanent inequality, transitory inequality and earnings immobility. First we look at the direct effect of shocks and institutions, and the interactions between institutions and the systemic shock (Model 2 in Table 
11). Second, we enhance the model by adding cross-interactions between institutions, and other controls (Model 3 in Table 11).

Model 2 in Table 11 illustrates the estimates for the direct effects of institutions, observed macroeconomic shocks, and the interactions between institutions and the systemic shock. The models for the three labour market outcomes explain $97.9 \%$ of the variation in permanent inequality, $92.9 \%$ of the variation in the transitory inequality and $68.9 \%$ of the variation in wage immobility.

Compared with Model 1, including the effects of the observed macroeconomic shocks and the interactions between institutions and the systemic shock (Model 2), affects the direct effects of the institutions on all three labour market outcomes. For transitory inequality and earnings immobility, however, the direct effects of the institutions change to a larger extent than for permanent inequality.

For permanent inequality, most coefficient estimates maintain the direction of influence and the significance level, except the union density which becomes insignificant, a high corporatism and the PMR which become negative, the ALMPs which become significant, and the unemployment benefit replacement rate which becomes positive and insignificant. Among those that maintained the direction of influence, the magnitude of the direct effects reduced in absolute value in Model 2 compared with Model 1, except for the ALMPs where it increased.

For transitory inequality, the EPL factors become significant, the degree of corporatism becomes positive and significant, and ALMPs become negative and insignificant. Among those that maintained the direction of influence and the significance, the magnitude of the effects decreased in absolute value in Model 2 compared with Model 1.

For earnings immobility, the EPL, the union density, and the high degree of corporatism become insignificant, the tax wedge becomes negative, the intermediate degree of corporatism becomes positive and insignificant, the ALMPs become negative and insignificant, and the unemployment benefit replacement rate becomes positive. Among those that maintained the direction of influence and the significance, the magnitude of the effects decreased in absolute value in Model 2 compared with Model 1. These results reinforce our expectation that the institutional factors are a "filtering mechanism" for the effects of the macro shocks on the three labour market outcomes. 
We turn to the direct effects of the macroeconomic shocks. As expected, permanent inequality appears to be affected directly by these shocks to a much lesser extent compared with transitory inequality and wage immobility: only the aggregate demand and the terms of trade shock are significant. For transitory inequality all shocks show a highly significant effect, and for wage immobility all except the aggregate labour supply shock.

For permanent inequality, a negative influence is observed for the terms of trade shock and a positive one for the aggregate demand shock. Transitory inequality is positively affected by the aggregate supply, the terms of trade and the total factor production shocks, and negatively by the rest. Wage immobility is affected negatively by the aggregate demand, the labour demand and the interest rate shock, and positively by the rest.

The explanation for the lack of significance of the direct effects of shock in explaining permanent inequality is found in the interaction effects between the institutional factors and the aggregate shock. All interaction effects are significant, except for ALMPs, suggesting that these policies and institution filter out the effects of the macro shocks. EPL, the relative difference between EPLR and EPLT and the tax wedge have a positive significant direct effect on permanent variance, which is amplified under the aggregate impact of these shocks. The positive significant effect of ALMPs is diminished under the impact of aggregate shocks, but the interaction term is not significant at conventional levels.

If for the directs effects the hump-shaped pattern of the relationship between the degree of corporatism and permanent inequality is confirmed, with the high level triggering the lowest permanent inequality, followed by low and intermediate corporatism, in interaction with aggregate shocks the degree of corporatism clearly becomes a tool for reducing permanent differentials: the higher is the degree of corporatism, the larger is the magnitude of the negative impact in reducing permanent inequality. The union density, the PMR and the unemployment benefit replacement rate have an insignificant direct effect, but in interaction with the aggregate shock they appear to work significantly towards increasing permanent differentials.

Compared with permanent inequality and wage immobility, fewer factors are significant in filtering out the effects of the systemic shock on transitory inequality. The direct effect for intermediate corporatism appears to trigger the highest transitory inequality, followed by high and low corporatism. In interaction with the aggregate shocks, however, the impact of an 
intermediate corporatism impact becomes insignificant, whereas for high corporatism it becomes negative and highly significant. Thus, similarly with permanent inequality, a high corporatism is an efficient tool in reducing or limiting the increase of transitory inequality under in the impact of macroeconomic shocks. A more generous unemployment benefit appears to have a significant positive impact on transitory inequality that is reduced in interaction with macroeconomic shocks.

The tax wedge does not have a significant direct effect on transitory inequality, but in interaction with macroeconomic shocks, it appears to be an efficient tool in reducing or limiting the increase of transitory inequality under the impact of macroeconomic shocks. The opposite holds for PMR and $\mathrm{ALMPs}^{30}$ : they have a negative direct effect, but in interaction with the systemic shock, they appear to have a positive impact on transitory inequality.

Wage immobility is explained to a lesser extent by the direct effects of institutions than permanent and transitory inequality. Most of the direct and interaction effects of shocks, however, are highly significant, suggesting that wage immobility is influenced mainly by the macroeconomic shocks and their interaction with the institutional setting. The relative difference between EPLR and EPLT and unemployment benefit generosity have a positive effect on wage immobility, which is diminished in interaction with the systemic shock. The effect of the systemic macroeconomic shock on wage immobility appears to increase significantly with the EPL, the union density, the PMR and the ALMPs, and to decrease with the degree of corporatism, the tax wedge, and the unemployment benefit replacement rate. An intermediate level of corporatism appears to be the most effective in reducing the impact of shocks, followed by a high and a low level of corporatism.

In order to grasp more in depth the nature of the relationship between institutions and shocks, these models are augmented by including also 2-by-2 interactions between the institutional factors, and other controls. The results are illustrated in Model 3 in Table 11. The new model specifications explain $98.9 \%$ of the variance in permanent inequality, $94.2 \%$ for transitory inequality and $80.6 \%$ for wage immobility.

\footnotetext{
${ }^{30}$ Albeit insignificant
} 
Including the institutional interaction effects and the other controls at the cohort level (the shares of university and upper- secondary graduates, the sector structure, the occupational structure, the share of unemployed, the share of permanent contracts), several changes are observed.

First, for permanent inequality, the direct effects of institutions and most of their cross interactions are highly significant, whereas all six macroeconomic shocks and their interactions with the institutional factors become insignificant, except for high corporatism. This suggests that the overall institutional structure manages to filter out all direct and indirect effect of these shocks. Hence, in shaping permanent inequality patterns, not the interactions between the systemic shock and the institutions count, but how institutions interact with each other in dealing with the effects of these shocks. One factor which interacts significantly with the aggregate shock is high corporatism, which decreases the impact of the aggregate macroeconomic shock on permanent inequality to a larger extent compared with low and intermediate corporatism.

All direct effects that were insignificant in the previous specification of the permanent inequality become significant once we control for cross-institutional interactions. Among those that were significant in Model 2, a change in sign is observed for the EPL, the relative difference between EPLR and EPLT, the tax wedge, and a high degree of corporatism.

EPL has a negative direct effect on permanent inequality, enhanced by the relative difference between EPLR and EPLT, and counteracted by the tax wedge. Union density has a positive direct effect, which increases in interaction with the tax wedge and decreases in interaction with PMR and ALPMs. The interaction with the degree of corporatism confirms the hump-shaped pattern hypothesis: the positive effect of the union density is enhanced in interaction with an intermediate level of corporatism, and counteracted in interaction with a high level of corporatism. The tax wedge has a negative direct effect on permanent inequality, which is accentuated in interaction with the PMR and the generosity of the unemployment benefit, and counteracted in interaction with the EPL, the union density and the ALMPs.

PMR has a positive direct effect, counteracted in interaction with the union density, the tax wedge and the ALMPs. ALMPs increases permanent inequality, effect which is accentuated in interaction with the tax wedge, and reduced in interaction with the PMR. Also union density and unemployment benefit lower the effect of ALMP, but the effect is not significant. 
Unemployment benefit has a negative direct effect on permanent inequality, which is reinforced by the tax wedge and the AMPLs ${ }^{31}$, and counteracted by PMR.

Second, for transitory inequality, similarly with permanent inequality, controlling for the interactions between institutions renders the direct and indirect effects of shocks insignificant. This reconfirms that the key role in shaping transitory and permanent inequality patterns is played by the interplay between labour market policies and institutions in dealing with macroeconomic shocks.

The direct effects on transitory inequality modify to large extent when these interactions are being introduced. Among those that remained significant, an intensification of the effects is recorded by the EPL, and a change in sign is recorded by the degree of corporatism, which exhibits a U-shaped relationship with transitory inequality: the lowest transitory inequality is triggered by an intermediate level, followed by a high level and a low level. The relative difference between EPLR and EPLT becomes insignificant, the unemployment benefit becomes negative and insignificant, the tax wedge negative and significant, and the union density becomes positive but remains insignificant.

EPL increases transitory inequality, but the effect is counteracted by an intermediate and a high corporatism, the tax wedge and the ALMPs. Union density has an insignificant positive direct effect, which decreases in interaction with an intermediate degree of corporatism, and increases in interaction with the tax wedge and the PMR. The tax wedge reduces transitory inequality, effect amplified by the EPL and the unemployment benefit replacement rate, and counteracted by union density. PMR has a negative direct effect, counteracted by the interaction effect with the union density. The ALMPs have a negative but insignificant direct effect, which is amplified in interaction with EPL. Similarly, the unemployment benefit replacement rate has an insignificant negative effect, which is amplified in interaction with the tax wedge.

Third, for earnings immobility, the inclusion of the cross-institution interactions renders all institutional factors highly significant, except the tax wedge and the ALMPs. Among those that remain significant, a change in sign is observed for the relative difference between the EPLR and EPLT, which turn negative. Among those that turn significant in the last specification, a change in sign is recorded for the union density, the degree of corporatism, and the PMR.

\footnotetext{
${ }^{31}$ Albeit not significant
} 
For the macro shocks and their interactions with the institutional setting, the inclusion of the cross-institutional interactions had the opposite effect compared with the permanent and transitory inequality. The direct effects of macroeconomic shocks increased in absolute value, kept the same direction of influence and remained highly significant, except for aggregate supply shock, which remained insignificant. Similarly, the interactions effects between institutions and the systemic shock maintained their direction of influence and the significance. One exception is the interaction with the relative EPLR-EPLT difference, which is insignificant in both specifications.

EPL has a strong positive effect on wage immobility, which increases in interaction with the union density and the aggregate macroeconomic shock, and decreases in interaction with the degree of corporatism and with the PMR.

Union density has a negative impact on wage immobility, which is counteracted by the interaction with the EPL, the tax wedge and aggregate macro shock.

Intermediate corporatism is associated with the lowest wage immobility, followed by high corporatism and low corporatism. The negative impact of high corporatism, however, is exacerbated in interaction with the EPL and the aggregate shock to a larger extent than for intermediate corporatism. The tax wedge has a positive, yet insignificant effect, which appears to increase significantly with the union density, and to decrease significantly with the ALMPs and the aggregate shock.

PMR lowers wage immobility, effect enhanced in interaction with the EPL, the unemployment replacement rate, and the union density ${ }^{32}$, and counteracted by the interaction with an intermediate and high corporatism, the ALMPs and the aggregate macro shock. In interaction with an intermediate corporatism, the positive impact on wage immobility is stronger than in the interaction with a high corporatism.

ALMPs has a negative, yet insignificant effect. Its interaction effects, however are significant: it decreases wage immobility when coupled with the tax wedge, and increases wage immobility in interaction with the PMR, the unemployment benefit replacement rate, and the aggregate shock.

\footnotetext{
${ }^{32}$ Insignificant at conventional levels
} 
Unemployment benefit increases wage immobility, effect which is accentuated when coupled with a high spending on ALMPs, and diminished when coupled with a high PMR. Moreover, in interaction with the systemic shock, the positive impact on wage immobility is being reduced.

\section{CONCLUding REMARKS}

Using the ECHP and OECD data, this paper explores the role of labour market policy and institutional factors in explaining cross-national differences in the evolution of permanent inequality, transitory inequality and earnings mobility across $14 \mathrm{EU}$ countries. So far, at the EU level, no study attempted to analyse and to understand the driving factors behind the three labour market outcomes in a comparative manner. In Europe, the most notable change after 1995, which is the approximate year of the turnaround in the labour market institutional and policy framework, represents the increased country heterogeneity, which translated itself in the level and the evolution of the cross-sectional earnings inequality components and earnings mobility.

Overall, the decrease in inequality resulted from a decrease in transitory differentials in Germany, France, UK and Ireland, in permanent differentials in Belgium and Spain, and in both components in Denmark and Austria. The increase in inequality reflects an increase in permanent differentials in Luxembourg, Italy, Greece and Finland, and an increase in both components in Portugal and Netherlands. The decrease in inequality was accompanied by an increase in mobility only in Denmark, Belgium and Spain. Except for Netherlands and Portugal, all countries recording an increase in inequality experienced also a decrease in mobility. Several common traits emerge across countries: the older the cohort, the higher the impact of permanent variance and wage immobility, and the lower the impact transitory inequality. Thus earnings volatility is higher at younger ages.

To what extent do labour market policies and institutional factors shape the pattern in permanent inequality, transitory inequality and earnings immobility? The estimation results reveal a highly complex framework, where institutions interact significantly not only with each other and with the overall institutional setting, but also with the macroeconomic shocks in shaping the pattern of the three labour market outcomes.

Permanent inequality and transitory inequality are determined mainly by the institutional setting, which wipe out both the direct and interaction effects of the macro shocks. This suggests that the 
overall institutional structure manages to filter out all direct and indirect effect of the macro shocks. Hence, in shaping permanent and transitory inequality patterns, not the individual interactions between shocks and each institution count, but how institutions interact with each other in dealing with the effects of these shocks. We identified more significant institutional direct and indirect effects for permanent inequality, sign that the institutional factors play a larger role in shaping permanent than transitory inequality. The only stand-alone factor which is effective in reducing or limiting the increase of permanent inequality under in the impact of macroeconomic shocks is the high degree of corporatism.

Earnings immobility is determined by the direct effects of institutions, macro shocks and their interactions with the institutional setting. The institutional and policy factors that amplify the positive impact of the systemic shock on wage immobility are the EPL, the union density, the PMR, the ALMPs. The factors that decrease the impact of the systemic shock on wage immobility are the degree of corporatism, and the generosity of the unemployment benefit.

The direct effects of the institutions are mixed, depending on the interactions included in the model. Controlling for cross-institutional interactions, macro shocks and their interactions with the institutional setting, a positive direct effect on permanent inequality is identified for the union density - which intensifies in interaction with an intermediate corporatism, and the tax wedge, and decreases in interaction with a high corporatism and the PMR -, for an intermediate corporatism - which increases in interaction with the union density -, for a high corporatism which decreases with union density -, for the PMR - which increases with the unemployment benefit replacement rate, and decreases in interaction with the union density, the tax wedge, and the ALMPs -, and for the ALMPs - which increases in interaction with the tax wedge, and decreases in interaction with the PMR. A negative effect is identified for the EPL - which intensifies in interaction with the relative EPL, and is counteracted in interaction with the tax wedge -, for the tax wedge - which is amplified in interaction with the PMR and the unemployment benefit replacement rate, and is counteracted in interaction with the EPL, the union density, and the ALMPs -, and for the unemployment benefit replacement rate - which intensifies with the tax wedge, and is counteracted in interaction with the PMR.

For transitory inequality, a positive direct effect is identified for the EPL - which decreases with an intermediate corporatism to a larger extent compared with a high corporatism, with the tax 
wedge, and with the ALMPs. A negative effect is identified for an intermediate corporatism which intensifies with the EPL and the union density -, for a high corporatism - which intensifies with the EPL -, for the tax wedge - which intensifies with the EPL and the unemployment benefit replacement rate, and is counteracted in interaction with union density -, for the PMR which is counteracted in interaction with union density.

For earnings immobility, a positive direct effect is recorded for the EPL - which intensifies with the union density, and decreases with the degree of corporatism and the PMR -, and for the unemployment benefit replacement rate - which increases with the ALMPs and decreases with the PMR. A negative effect is observed for the union density - which is counteracted in interaction with the EPL and the tax wedge -, for the degree of corporatism - which intensifies in interaction with EPL, and is counteracted in interaction with the PMR -, for the PMR - which intensifies in interaction with the EPL and the unemployment benefit replacement rate, and is counteracted in interaction with the degree of corporatism and the ALMPs.

The systemic interactions reveal that the more equality/mobility-friendly the overall labour market policy and institutional framework is, the greater is the reducing impact: (i) of the union density, the degree of corporatism - a stronger reducing effect for an intermediate level than for a high level -, the tax wedge and the product market regulation on permanent inequality; (ii) of the union density and the degree of corporatism on transitory inequality; and (iii) of the union density and the degree of corporatism - a stronger reducing effect for an intermediate level than for a high level - on earnings immobility.

To conclude, a highly complex institutional mechanism is at work in shaping the pattern of the three labour market outcomes. This complexity is enhanced by the endogeneity bias characterising this framework, which in the absence of reliable instruments, prevents the establishment of causality. 


\section{TABLES AND Figures}

Table 1. Mean hourly earnings and number of individuals with positive earnings

\begin{tabular}{|c|c|c|c|c|c|c|c|c|c|}
\hline & & 1994 & 1995 & 1996 & 1997 & 1998 & 1999 & 2000 & 2001 \\
\hline \multirow[t]{2}{*}{ Germany } & Mean & 9.43 & 9.49 & 9.61 & 9.52 & 9.57 & 9.48 & 9.60 & 9.72 \\
\hline & $\mathrm{N}$ & 25018 & 26059 & 25806 & 24889 & 23290 & 22955 & 21909 & 20703 \\
\hline \multirow[t]{2}{*}{ Denmark } & Mean & 10.89 & 11.40 & 11.58 & 11.61 & 11.86 & 11.85 & 12.02 & 12.08 \\
\hline & $\mathrm{N}$ & 20899 & 20399 & 19190 & 19062 & 17321 & 16235 & 15678 & 15380 \\
\hline \multirow[t]{2}{*}{ Netherlands } & Mean & 9.69 & 9.56 & 9.59 & 9.70 & 10.02 & 9.88 & 10.04 & 9.91 \\
\hline & $\mathrm{N}$ & 33277 & 32384 & 31564 & 30575 & 28731 & 27460 & 25790 & 33277 \\
\hline \multirow[t]{2}{*}{ Belgium } & Mean & 8.48 & 8.82 & 8.71 & 8.75 & 8.81 & 8.83 & 8.92 & 9.10 \\
\hline & $\mathrm{N}$ & 20221 & 22100 & 22892 & 22753 & 22863 & 23233 & 24065 & 24130 \\
\hline \multirow[t]{2}{*}{ Luxembourg } & Mean & & 16.18 & 15.81 & 16.73 & 17.39 & 17.15 & 17.22 & 17.10 \\
\hline & $\mathrm{N}$ & & 15829 & 13695 & 14489 & 13403 & 14075 & 12667 & 12992 \\
\hline \multirow[t]{2}{*}{ France $^{33}$} & Mean & 10.23 & 9.92 & 9.87 & 10.05 & 10.33 & 10.60 & 10.55 & 10.87 \\
\hline & $\mathrm{N}$ & 20137 & 19270 & 19042 & 17906 & 14467 & 14012 & 13760 & 14212 \\
\hline \multirow[t]{2}{*}{ UK } & Mean & 8.16 & 8.11 & 8.22 & 8.34 & 8.68 & 9.01 & 9.21 & 9.68 \\
\hline & $\mathrm{N}$ & 24949 & 25329 & 25495 & 26010 & 26145 & 25750 & 25674 & 25264 \\
\hline \multirow[t]{2}{*}{ Ireland } & Mean & 9.30 & 9.54 & 9.76 & 10.02 & 10.43 & 10.84 & 11.69 & 12.44 \\
\hline & $\mathrm{N}$ & 13937 & 13221 & 12590 & 12515 & 12435 & 12091 & 10745 & 9727 \\
\hline \multirow[t]{2}{*}{ Italy } & Mean & 7.16 & 6.91 & 6.96 & 7.05 & 7.29 & 7.37 & 7.28 & 7.32 \\
\hline & $\mathrm{N}$ & 32633 & 32236 & 32111 & 29661 & 28865 & 26993 & 26912 & 25170 \\
\hline \multirow[t]{2}{*}{ Greece } & Mean & 4.95 & 5.03 & 5.23 & 5.59 & 5.63 & 5.85 & 5.70 & 5.77 \\
\hline & $\mathrm{N}$ & 27974 & 27654 & 26150 & 24865 & 22675 & 22001 & 21335 & 21929 \\
\hline \multirow[t]{2}{*}{ Spain } & Mean & 6.83 & 6.95 & 7.09 & 6.89 & 7.18 & 7.37 & 7.45 & 7.42 \\
\hline & $\mathrm{N}$ & 22559 & 21863 & 21296 & 20975 & 20371 & 20580 & 19898 & 20185 \\
\hline \multirow[t]{2}{*}{ Portugal } & Mean & 9.08 & 8.33 & 8.37 & 8.49 & 8.55 & 8.55 & 8.54 & 9.08 \\
\hline & $\mathrm{N}$ & 14653 & 15450 & 15379 & 15087 & 14837 & 14569 & 14604 & 14550 \\
\hline \multirow[t]{2}{*}{ Austria } & Mean & & 9.08 & 8.33 & 8.37 & 8.49 & 8.55 & 8.55 & 8.54 \\
\hline & $\mathrm{N}$ & & 17944 & 17789 & 17199 & 16209 & 15162 & 13816 & 13056 \\
\hline \multirow[t]{2}{*}{ Finland } & Mean & & & 7.89 & 8.01 & 8.41 & 8.45 & 8.66 & 8.86 \\
\hline & $\mathrm{N}$ & & & 15811 & 15845 & 15895 & 15546 & 13329 & 13057 \\
\hline
\end{tabular}

Note: Mean hourly earnings are expressed in Euro.

\footnotetext{
${ }^{33}$ Gross Amounts
} 


\section{Table 2. Description of OECD variables}

\begin{tabular}{|c|c|}
\hline OECD Variables & Description \\
\hline \multicolumn{2}{|c|}{ Source: Bassanini and Duval (2006) } \\
\hline $\begin{array}{l}\text { EPL = Employment } \\
\text { Protection Legislation }\end{array}$ & $\begin{array}{l}\text { OECD summary indicator of the stringency of Employment Protection Legislation. EPL ranges } \\
\text { from } 0 \text { to } 6 .\end{array}$ \\
\hline $\begin{array}{l}\text { EPLR = Employment } \\
\text { Protection Legislation for } \\
\text { regular contracts }\end{array}$ & $\begin{array}{l}\text { OECD summary indicator of the stringency of Employment Protection Legislation for regular } \\
\text { contracts }\end{array}$ \\
\hline $\begin{array}{l}\text { EPLT }=\text { Employment } \\
\text { Protection Legislation for } \\
\text { temporary contracts }\end{array}$ & $\begin{array}{l}\text { OECD summary indicator of the stringency of Employment Protection Legislation for temporary } \\
\text { contracts }\end{array}$ \\
\hline Union Density & Trade union density rate, i.e. the share of workers affiliated to a trade union, in \%. \\
\hline Union Coverage & $\begin{array}{l}\text { Collective bargaining coverage rate, i.e. the share of workers covered by a collective agreement, in } \\
\% \text {. }\end{array}$ \\
\hline Degree of Corporatism & $\begin{array}{l}\text { Indicator of the degree of centralisation/co-ordination of the wage bargaining processes, which } \\
\text { takes values } 1 \text { for decentralised and uncoordinated processes, and } 2 \text { and } 3 \text { for intermediate and high }\end{array}$ \\
\hline Tax Wedge & $\begin{array}{l}\text { The tax wedge expresses the sum of personal income tax and all social security contributions as a } \\
\text { percentage of total labour cost. }\end{array}$ \\
\hline $\begin{array}{l}\text { PMR } \\
=\text { Product Market } \\
\text { Regulation }\end{array}$ & $\begin{array}{l}\text { OECD summary indicator of regulatory impediments to product market competition in seven non- } \\
\text { manufacturing industries. The data used in this paper cover regulations and market conditions in } \\
\text { seven energy and service industries. PMR ranges from } 0 \text { to } 6 \text {. }\end{array}$ \\
\hline $\begin{array}{l}\text { ALMPs = Public } \\
\text { expenditures on active } \\
\text { labour market } \\
\text { policies }\end{array}$ & $\begin{array}{l}\text { Public expenditures on active labour market programmes per unemployed worker as a share of } \\
\text { GDP per capita, in } \% \text {. }\end{array}$ \\
\hline $\begin{array}{l}\text { Average unemployment } \\
\text { benefit replacement rate }\end{array}$ & $\begin{array}{l}\text { Average unemployment benefit replacement rate across two income situations ( } 100 \% \text { and } 67 \% \text { of } \\
\text { APW earnings), three family situations (single, with dependent spouse, with spouse in work) }\end{array}$ \\
\hline Labour Demand Shock & $\begin{array}{l}\text { Logarithm of the labour share in business sector GDP purged from the short-run influence of factor } \\
\text { prices. }\end{array}$ \\
\hline Terms of Trade Shock & Logarithm of the relative price of imports weighted by the share of imports in GDP \\
\hline $\begin{array}{l}\text { Total Factor Productivity } \\
\text { Shock }\end{array}$ & $\begin{array}{l}\text { Deviation of the logarithm of Total Factor Productivity (TFP) from its trend calculated by means of } \\
\text { a Hodrick-Prescott (HP) filter (smoothing parameter } \lambda=100 \text { ) }\end{array}$ \\
\hline Real Interest Shock & $\begin{array}{l}\text { Difference between the 10-year nominal government bond yield (in \%) and the annual change in } \\
\text { the GDP deflator (in \%). }\end{array}$ \\
\hline \multicolumn{2}{|c|}{ Lindert-Allard OECD data sets 1950-2001 } \\
\hline Aggregate Supply Shock & $\begin{array}{l}\text { At the OECD level, amplified by openness = (INFLOECD- } \\
\text { UNCHOECD)*OPEN/100, INFLOECD = inflation for the OECD as a whole, } \\
\text { averaged over the } 21 \text { countries, UNCHOECD= Three-year change in the } \\
\text { unemployment rate for the OECD as a whole) OPEN= (exports + imports) as a } \\
\text { percentage of GDP, from Penn World Tables }\end{array}$ \\
\hline Aggregate Demand Shock & $\begin{array}{l}\text { At the OECD level, amplified by openness= } \\
\text { (INFLOECD+UNCHOECD)*OPEN/100 }\end{array}$ \\
\hline
\end{tabular}


Table 3. Institutional Variables - Summary Statistics

\begin{tabular}{|c|c|c|c|c|c|c|}
\hline Variable & & Mean & Std. Dev. & Min & Max & Observations \\
\hline \multirow[t]{3}{*}{$\overline{\mathrm{EPL}}$} & overall & 2.417 & 0.943 & 0.6 & 3.854 & $\mathrm{~N}=$ \\
\hline & between & & 0.943 & 0.621 & 3.739 & $\mathrm{n}=13$ \\
\hline & within & & 0.247 & 1.53 & 3.204 & $\mathrm{~T}=$ \\
\hline \multirow[t]{3}{*}{ EPLT } & overall & 2.5 & 1.446 & 0.25 & 5.375 & $\mathrm{~N}=104$ \\
\hline & between & & 1.41 & 0.25 & 4.75 & $\mathrm{n}=13$ \\
\hline & within & & 0.489 & 0.747 & 4.031 & $\mathrm{~T}=$ \\
\hline \multirow[t]{3}{*}{ EPLR } & overall & 2.33 & 0.837 & 0.948 & 4.333 & $\mathrm{~N}=104$ \\
\hline & between & & 0.858 & 0.99 & 4.333 & $\mathrm{n}=13$ \\
\hline & within & & 0.06 & 2.166 & 2.555 & $\mathrm{~T}=$ \\
\hline \multirow[t]{3}{*}{$($ EPLR-EPLT)/EPLT]*100 } & overall & 0.672 & 1.659 & -0.67 & 5.413 & $\mathrm{~N}=104$ \\
\hline & between & & 1.704 & -0.553 & 5.413 & $\mathrm{n}=13$ \\
\hline & within & & 0.214 & 0.162 & 1.466 & $\mathrm{~T}=$ \\
\hline \multirow[t]{3}{*}{ Union Density } & overall & 37.885 & 19.602 & 9.636 & 79.386 & $\mathrm{~N}=112$ \\
\hline & between & & 20.171 & 9.788 & 78.07 & $\mathrm{n}=14$ \\
\hline & within & & 1.745 & 31.025 & 43.705 & $\mathrm{~T}=$ \\
\hline \multirow[t]{3}{*}{ Degree of Corporatism } & overall & 2.583 & 0.644 & 1 & 3 & $\mathrm{~N}=$ \\
\hline & between & & 0.669 & 1 & 3 & $\mathrm{n}=$ \\
\hline & within & & 0 & 2.583 & 2.583 & $\mathrm{~T}=$ \\
\hline \multirow[t]{3}{*}{ Tax Wedge } & overall & 32.65 & 6.886 & 12.802 & 44.9 & $\mathrm{~N}=$ \\
\hline & between & & 6.787 & 21.935 & 40.547 & $\mathrm{n}=$ \\
\hline & within & & 2.177 & 23.516 & 39.123 & $\mathrm{~T}=$ \\
\hline \multirow[t]{3}{*}{ PMR } & overall & 3.4 & 1.003 & 1.133 & 5.236 & $\mathrm{~N}=$ \\
\hline & between & & 0.86 & 1.454 & 4.415 & $\mathrm{n}=12$ \\
\hline & within & & 0.567 & 2.162 & 4.465 & $\mathrm{~T}=$ \\
\hline \multirow[t]{3}{*}{ ALMPs } & overall & & & & & $\mathrm{N}=$ \\
\hline & between & 29.778 & 20.685 & 4.81 & 126.1 & $\mathrm{n}=$ \\
\hline & within & & 18.843 & 9.362 & 74.995 & $\mathrm{~T}=$ \\
\hline \multirow[t]{3}{*}{ Unemployment Benefit RR } & overall & & 9.949 & -3.8 & 80.883 & $\mathrm{~N}=$ \\
\hline & between & 35.982 & 11.491 & 16.589 & 64.944 & $\mathrm{n}=$ \\
\hline & within & & 11.534 & 17.44 & 59.87 & $\mathrm{~T}=8$ \\
\hline \multirow[t]{3}{*}{ Labour demand shock } & overall & 0.062 & 0.062 & -0.075 & 0.167 & $\mathrm{~N}=$ \\
\hline & between & & 0.063 & -0.068 & 0.147 & $\mathrm{n}=$ \\
\hline & within & & 0.013 & 0.028 & 0.099 & $\mathrm{~T}=7.727$ \\
\hline \multirow[t]{3}{*}{ Terms of Trade Shocks } & overall & -0.094 & 0.040 & -0.178 & -0.027 & $\mathrm{~N}=$ \\
\hline & between & & 0.035 & -0.146 & -0.042 & $\mathrm{n}=$ \\
\hline & within & & 0.022 & -0.142 & -0.041 & $\mathrm{~T}=7.75$ \\
\hline \multirow[t]{3}{*}{ Total Factor Production Shock } & overall & 0.007 & 0.016 & -0.058 & 0.047 & $\mathrm{~N}=$ \\
\hline & between & & 0.007 & -0.001 & 0.019 & $\mathrm{n}=$ \\
\hline & within & & 0.015 & -0.056 & 0.049 & $\mathrm{~T}=7.727$ \\
\hline \multirow[t]{3}{*}{ Real Interest Shock } & overall & 0.039 & 0.018 & -0.016 & 0.080 & $\mathrm{~N}=$ \\
\hline & between & & 0.007 & 0.023 & 0.045 & $\mathrm{n}=$ \\
\hline & within & & 0.017 & -0.001 & 0.088 & $\mathrm{~T}=7.75$ \\
\hline \multirow[t]{3}{*}{ Aggregate Labour Supply } & overall & 1.855 & 2.084 & -0.635 & 8.145 & $\mathrm{~N}=$ \\
\hline & between & & 0.924 & 1.054 & 3.692 & $\mathrm{n}=$ \\
\hline & within & & 1.881 & -2.472 & 6.308 & $\mathrm{~T}=7.769$ \\
\hline \multirow[t]{3}{*}{ Aggregate Labour Demand } & overall & 3.388 & 1.776 & 1.175 & 8.158 & $\mathrm{~N}=$ \\
\hline & between & & 1.581 & 2.051 & 6.578 & $\mathrm{n}=$ \\
\hline & within & & 0.871 & 0.534 & 4.968 & $\mathrm{~T}=7.769$ \\
\hline
\end{tabular}


Table 4. The evolution of the labour market policies and institutional factors 1994-2001

\begin{tabular}{|c|c|c|c|c|c|c|c|c|c|c|c|c|c|c|c|c|c|c|c|c|}
\hline \multirow{2}{*}{$\begin{array}{l}\text { Year } \\
1994\end{array}$} & \multirow{2}{*}{$\begin{array}{l}\text { Country } \\
\text { AUT }\end{array}$} & \multicolumn{2}{|l|}{ EPL } & \multicolumn{2}{|c|}{ EPLR } & \multicolumn{2}{|l|}{ EPLT } & \multirow{2}{*}{$\begin{array}{l}\text { Relative } \\
\text { EPL } \\
0.94\end{array}$} & \multicolumn{2}{|c|}{$\begin{array}{l}\text { Union } \\
\text { Density }\end{array}$} & \multicolumn{2}{|l|}{ PMR } & \multicolumn{2}{|c|}{ Tax Wedge } & \multicolumn{2}{|c|}{ Corporatism } & \multicolumn{2}{|c|}{$\begin{array}{l}\text { Unempl. Benefit } \\
\text { Replacement Rate }\end{array}$} & \multicolumn{2}{|l|}{ ALMPs } \\
\hline & & 2.20 & ML & 2.92 & ML & 1.50 & $\mathrm{~L}$ & & 41.43 & ML & 4.19 & $\mathrm{H}$ & 24.60 & ML & 3.00 & $\mathrm{H}$ & 29.55 & $\mathrm{M}$ & 20.34 & ML \\
\hline 2001 & AUT & 2.20 & ML & 2.92 & ML & 1.50 & $\mathrm{~L}$ & 0.94 & 35.68 & ML & 2.66 & ML & 25.40 & ML & 3.00 & $\mathrm{H}$ & 31.52 & $\mathrm{MH}$ & 29.91 & ML \\
\hline 1994 & BEL & 3.20 & MH & 1.68 & $\mathrm{~L}$ & 4.63 & $\mathrm{H}$ & -0.64 & 54.69 & MH & 4.49 & $\mathrm{H}$ & 38.60 & $\mathrm{H}$ & 3.00 & $\mathrm{H}$ & 39.56 & MH & 24.22 & ML \\
\hline 2001 & BEL & 2.20 & MH & 1.73 & $\mathrm{~L}$ & 2.63 & ML & -0.34 & 55.76 & $\mathrm{MH}$ & 2.54 & M & 40.30 & $\mathrm{H}$ & 3.00 & $\mathrm{H}$ & 38.49 & $\mathrm{MH}$ & 30.51 & ML \\
\hline 1994 & DNK & 2.30 & ML & 1.52 & $\mathrm{~L}$ & 3.13 & MH & -0.51 & 77.51 & $\mathrm{H}$ & 4.07 & $\mathrm{H}$ & 30.30 & MH & 3.00 & $\mathrm{H}$ & 58.11 & VH & 40.89 & MH \\
\hline 1994 & FRA & 3.00 & M & 2.34 & ML & 3.63 & MH & -0.35 & 10.02 & $\mathrm{~L}$ & 4.85 & $\mathrm{H}$ & 39.30 & $\mathrm{H}$ & 2.00 & M & 37.56 & $\mathrm{MH}$ & 24.04 & ML \\
\hline 2001 & FRA & 3.00 & M & 2.47 & ML & 3.63 & $\mathrm{MH}$ & -0.32 & 9.64 & L & 3.74 & MH & 39.40 & $\mathrm{H}$ & 2.00 & M & 43.53 & $\mathrm{H}$ & 33.09 & ML \\
\hline 1994 & IRL & 0.90 & VL & 1.60 & $\mathrm{~L}$ & 0.25 & VL & 5.41 & 48.60 & M & 4.70 & $\mathrm{H}$ & 28.41 & ML & 3.00 & $\mathrm{H}$ & 28.54 & M & 26.42 & ML \\
\hline 2001 & IRL & 0.90 & VL & 1.60 & $\mathrm{~L}$ & 0.25 & VL & 5.41 & 35.92 & ML & 3.54 & $\mathrm{H}$ & 12.80 & $\mathrm{~L}$ & 3.00 & $\mathrm{H}$ & 35.84 & $\mathrm{MH}$ & 67.33 & $\mathrm{H}$ \\
\hline 1994 & ITA & 3.60 & MH & 1.77 & $\mathrm{~L}$ & 5.38 & VH & -0.67 & 38.73 & ML & 5.24 & $\mathrm{H}$ & 43.50 & $\mathrm{H}$ & 3.00 & $\mathrm{H}$ & 18.00 & $\mathrm{~L}$ & 7.97 & VL \\
\hline 2001 & ITA & 2.14 & ML & 1.77 & $\mathrm{~L}$ & 2.50 & ML & -0.29 & 34.85 & ML & 3.18 & MH & 35.40 & MH & 3.00 & $\mathrm{H}$ & 34.14 & MH & 16.03 & $\mathrm{~L}$ \\
\hline 2001 & NLD & 2.10 & ML & 3.05 & $\mathrm{MH}$ & 1.19 & $\mathrm{~L}$ & 1.57 & 22.50 & $\mathrm{~L}$ & 1.81 & $\mathrm{~L}$ & 33.00 & MH & 3.00 & $\mathrm{H}$ & 52.86 & $\mathrm{H}$ & 126.10 & VH \\
\hline 1994 & PRT & 3.85 & MH & 4.33 & $\mathrm{H}$ & 3.38 & $\mathrm{MH}$ & 0.28 & 27.31 & $\mathrm{~L}$ & 4.94 & $\mathrm{H}$ & 27.05 & ML & 2.00 & M & 35.39 & $\mathrm{MH}$ & 20.30 & ML \\
\hline 2001 & PRT & 3.70 & MH & 4.33 & $\mathrm{H}$ & 3.00 & M & 0.44 & 23.43 & $\mathrm{~L}$ & 3.05 & $\mathrm{M}$ & 24.09 & ML & 2.00 & M & 41.25 & $\mathrm{H}$ & 30.36 & ML \\
\hline 1994 & ESP & 3.11 & $\mathrm{MH}$ & 2.97 & ML & 3.25 & $\mathrm{MH}$ & -0.09 & 17.64 & $\mathrm{~L}$ & 4.27 & $\mathrm{H}$ & 33.70 & MH & 2.00 & M & 35.35 & MH & 4.81 & VL \\
\hline 2001 & ESP & 3.10 & MH & 2.61 & ML & 3.50 & $\mathrm{MH}$ & -0.26 & 13.78 & $\mathrm{~L}$ & 2.43 & ML & 31.10 & $\mathrm{MH}$ & 2.00 & M & 36.46 & $\mathrm{MH}$ & 18.34 & $\mathrm{~L}$ \\
\hline 1994 & GBR & 0.60 & VL & 0.95 & VL & 0.25 & VL & 2.79 & 34.16 & ML & 1.87 & $\mathrm{~L}$ & 25.20 & ML & 1.00 & $\mathrm{~L}$ & 18.13 & $\mathrm{~L}$ & 11.19 & VL \\
\hline 2001 & GBR & 0.68 & VL & 1.12 & $\mathrm{~L}$ & 0.25 & VL & 3.46 & 30.73 & ML & 1.13 & $\mathrm{~L}$ & 18.10 & $\mathrm{~L}$ & 1.00 & $\mathrm{~L}$ & 16.59 & $\mathrm{~L}$ & 15.84 & $\mathrm{~L}$ \\
\hline 1994 & FIN & 2.17 & ML & 2.47 & ML & 1.88 & $\mathrm{~L}$ & 0.32 & 78.02 & $\mathrm{H}$ & 3.62 & MH & 40.47 & $\mathrm{H}$ & 3.00 & $\mathrm{H}$ & 37.09 & $\mathrm{MH}$ & 20.41 & ML \\
\hline 2001 & FIN & 2.00 & $\mathrm{~L}$ & 2.17 & ML & 1.88 & $\mathrm{~L}$ & 0.16 & 77.82 & $\mathrm{H}$ & 2.47 & ML & 38.80 & $\mathrm{H}$ & 3.00 & $\mathrm{H}$ & 34.78 & MH & 20.62 & ML \\
\hline 1994 & DEU & 3.09 & MH & 2.68 & ML & 3.50 & MH & -0.23 & 30.38 & ML & 3.88 & MH & 35.70 & MH & 3.00 & $\mathrm{H}$ & 27.06 & ML & 32.52 & ML \\
\hline 2001 & DEU & 2.50 & ML & 2.68 & ML & 2.25 & ML & 0.19 & 23.53 & $\mathrm{~L}$ & 2.03 & $\mathrm{~L}$ & 32.70 & MH & 3.00 & $\mathrm{H}$ & 27.69 & ML & 31.93 & ML \\
\hline 1994 & LUX & & & & & & & & 42.60 & ML & & & & & & & & & & \\
\hline 2001 & LUX & & & & & & & & 37.37 & ML & & & & & & & & & & \\
\hline 2001 & GR & 3.54 & MH & 2.33 & ML & 4.75 & $\mathrm{H}$ & -0.51 & 26.73 & $\mathrm{~L}$ & & & & & & & & & & \\
\hline
\end{tabular}


Table 5. Share of employees by educational level, by sector, by type of contract, by employment status, by occupational - for selected cohorts based on ECHP

\begin{tabular}{l|l|ll|ll|ll|ll|ll}
\hline \multicolumn{2}{l}{ Variable } & Cohort & $1940-1950$ & Cohort & $1951-1960$ & Cohort 1961-1970 & Cohort 1971-1981 \\
\hline Share of University Degree & 108 & 0.228 & 0.115 & 0.248 & 0.128 & 0.250 & 0.130 & 0.134 & 0.144 \\
Share of Upper-Sec Degree & 108 & 0.327 & 0.191 & 0.367 & 0.177 & 0.401 & 0.195 & 0.451 & 0.197 \\
Share of permanent contracts & 108 & 0.896 & 0.074 & 0.875 & 0.060 & 0.849 & 0.087 & 0.755 & 0.170 \\
Share of private employees & 108 & 0.657 & 0.096 & 0.678 & 0.082 & 0.789 & 0.052 & 0.860 & 0.055 \\
Share of Unemployed & 108 & 0.068 & 0.033 & 0.057 & 0.037 & 0.078 & 0.043 & 0.129 & 0.096 \\
Occupation Structure (ECHP) & & & & & & & & & \\
Share of occupation 1 & 108 & 0.118 & 0.044 & 0.109 & 0.045 & 0.077 & 0.041 & 0.021 & 0.022 \\
Share of occupation 2 & 108 & 0.112 & 0.049 & 0.116 & 0.047 & 0.103 & 0.044 & 0.042 & 0.032 \\
Share of occupation 3 & 108 & 0.099 & 0.039 & 0.118 & 0.044 & 0.111 & 0.045 & 0.069 & 0.035 \\
Share of occupation 4 & 108 & 0.057 & 0.028 & 0.069 & 0.040 & 0.072 & 0.026 & 0.056 & 0.026 \\
Share of occupation 5 & 108 & 0.046 & 0.021 & 0.057 & 0.024 & 0.065 & 0.023 & 0.074 & 0.029 \\
Share of occupation 6 & 108 & 0.052 & 0.042 & 0.042 & 0.025 & 0.037 & 0.025 & 0.024 & 0.017 \\
Share of occupation 7 & 108 & 0.160 & 0.046 & 0.185 & 0.054 & 0.197 & 0.062 & 0.165 & 0.071 \\
Share of occupation 8 & 108 & 0.093 & 0.029 & 0.102 & 0.025 & 0.101 & 0.024 & 0.066 & 0.021 \\
Share of occupation 9 & 108 & 0.052 & 0.022 & 0.062 & 0.023 & 0.063 & 0.026 & 0.066 & 0.032 \\
\hline
\end{tabular}


Table 6. Error-Components Models for Log Real Hourly Earnings

\begin{tabular}{|c|c|c|c|c|c|c|c|c|c|c|c|c|c|c|}
\hline & \multicolumn{2}{|c|}{$\begin{array}{l}\text { Germany } \\
\text { RG+AR1 }\end{array}$} & \multicolumn{2}{|c|}{$\begin{array}{l}\text { Denmark } \\
\text { RW+AR1 }\end{array}$} & \multicolumn{2}{|c|}{$\begin{array}{l}\text { Netherlands } \\
\text { RG+AR1 }\end{array}$} & \multicolumn{2}{|c|}{$\begin{array}{l}\text { Belgium } \\
\text { PI+AR1 }\end{array}$} & \multicolumn{2}{|l|}{$\begin{array}{l}\text { France } \\
\text { PI+AR1 }\end{array}$} & \multicolumn{2}{|c|}{$\begin{array}{l}\text { Luxembourg } \\
\text { PI+AR1 }\end{array}$} & \multicolumn{2}{|c|}{$\begin{array}{l}\text { UK } \\
\text { RG+AR1 }\end{array}$} \\
\hline & Param. & SE & Param. & SE & Param & SE & Param & SE & Param & SE & Param & SE & Param & SE \\
\hline \multicolumn{15}{|l|}{ Permanent Component } \\
\hline $\exp ($ estimate $)=\sigma_{\mu}^{2}$ & 7.2609 & 0.0867 & 0.0078 & 0.2653 & 0.1913 & 0.0905 & 0.0698 & 0.0246 & 0.1653 & 0.0293 & 0.1071 & 0.0251 & 0.0467 & 0.2467 \\
\hline $\exp ($ estimate $)=\sigma_{\varphi}^{2}$ & 0.0024 & 0.0968 & & & 0.0002 & 0.0797 & & & & & & & 0.0001 & 0.1032 \\
\hline $\operatorname{cov}(\mu, \varphi)$ & -0.1313 & 0.0121 & & & -0.0052 & 0.0005 & & & & & & & -0.0022 & 0.0004 \\
\hline $\exp ($ estimate $)=\sigma_{\pi}^{2}$ & & & 0.0001 & 0.0745 & & & & & & & & & & \\
\hline \multicolumn{15}{|l|}{ Time shifters, $\lambda_{1,1994}=1$} \\
\hline$\lambda_{1,1995}$ & 1.0734 & 0.0084 & 0.9709 & 0.0203 & 0.9735 & 0.0158 & 0.9421 & 0.0116 & 1.0511 & 0.0129 & 1 & & 0.9915 & 0.0082 \\
\hline$\lambda_{1,1996}$ & 1.1503 & 0.0112 & 0.9241 & 0.0201 & 0.9748 & 0.0172 & 1.0041 & 0.0122 & 1.1058 & 0.0130 & 1.0215 & 0.0220 & 0.9070 & 0.0103 \\
\hline$\lambda_{1,1997}$ & 1.2028 & 0.0142 & 0.8193 & 0.0214 & 0.9334 & 0.0159 & 0.9225 & 0.0145 & 1.1338 & 0.0144 & 1.1810 & 0.0208 & 0.9228 & 0.0126 \\
\hline$\lambda_{1,1998}$ & 1.2720 & 0.0215 & 0.8070 & 0.0231 & 0.9876 & 0.0169 & 0.8915 & 0.0160 & 1.1295 & 0.0173 & 1.2493 & 0.0222 & 0.8936 & 0.0146 \\
\hline$\lambda_{1,1999}$ & 1.4078 & 0.0188 & 0.7048 & 0.0228 & 0.8963 & 0.0184 & 0.7853 & 0.0162 & 1.1257 & 0.0181 & 1.3205 & 0.0248 & 0.8571 & 0.0154 \\
\hline$\lambda_{1,2000}$ & 1.5155 & 0.0222 & 0.6578 & 0.0251 & 0.8749 & 0.0193 & 0.9245 & 0.0170 & 1.0581 & 0.0188 & 1.3425 & 0.0314 & 0.7802 & 0.0163 \\
\hline$\lambda_{1,2001}$ & 1.4744 & 0.0280 & 0.6657 & 0.0235 & 0.9096 & 0.0208 & 0.9207 & 0.0156 & 1.0842 & 0.0186 & 1.2977 & 0.0222 & 0.7982 & 0.0175 \\
\hline \multicolumn{15}{|l|}{ Cohort shifters, $\gamma_{1,40-50}=1$} \\
\hline$\gamma_{1,51-60}$ & 0.4401 & 0.0145 & 1.2694 & 0.0339 & 1.2748 & 0.0424 & 1.0127 & 0.0138 & 0.8589 & 0.0139 & 0.9557 & 0.0189 & 1.4131 & 0.0301 \\
\hline$\gamma_{1,61-70}$ & 0.2031 & 0.0088 & 1.6459 & 0.1164 & 1.3168 & 0.1144 & 0.7776 & 0.0105 & 0.7796 & 0.0131 & 0.9396 & 0.0183 & 2.0459 & 0.0992 \\
\hline$\gamma_{1,71-80}$ & 0.0856 & 0.0046 & 1.4783 & 0.2034 & 0.7891 & 0.0704 & 0.1425 & 0.0387 & 0.5000 & 0.0178 & 0.5933 & 0.0183 & 2.4514 & 0.2435 \\
\hline \multicolumn{15}{|l|}{ Transitory Component } \\
\hline $\exp ($ estimate $)=\sigma_{\varepsilon}^{2}$ & 0.2578 & 0.5741 & 0.2604 & 0.2961 & 0.1262 & 0.3096 & 0.2439 & 0.1523 & 0.7969 & 0.5779 & 0.0186 & 0.1671 & 0.0702 & 0.1110 \\
\hline
\end{tabular}




\begin{tabular}{|c|c|c|c|c|c|c|c|c|c|c|c|c|c|c|}
\hline $\exp ($ estimate $)=\sigma_{0,40-50}^{2}$ & 0.0044 & 0.7316 & 0.0314 & 0.0851 & 0.0228 & 0.0913 & 0.0639 & 0.0437 & 0.1039 & 0.0491 & 0.0753 & 0.0638 & 0.0764 & 0.0437 \\
\hline $\exp ($ estimate $)=\sigma_{0,51-60}^{2}$ & 0.0562 & 0.0887 & 0.0224 & 0.0813 & 0.0271 & 0.1208 & 0.0357 & 0.0663 & 0.0913 & 0.0902 & 0.1064 & 0.1109 & 0.0789 & 0.0605 \\
\hline $\exp ($ estimate $)=\sigma_{0,61-70}^{2}$ & 0.0419 & 0.0940 & 0.0334 & 0.0740 & 0.0112 & 0.2073 & 0.0392 & 0.0535 & 0.0486 & 0.0843 & 0.0672 & 0.1136 & 0.0750 & 0.0681 \\
\hline $\exp ($ estimate $)=\sigma_{0,71-80}^{2}$ & 0.0832 & 0.0679 & 0.0269 & 0.0712 & 0.0406 & 0.0962 & 0.0347 & 0.0596 & 0.0956 & 0.0966 & 0.0225 & 0.1220 & 0.0313 & 0.1179 \\
\hline$\rho$ & 0.3583 & 0.0223 & 0.5459 & 0.0135 & 0.3289 & 0.0118 & 0.6280 & 0.0104 & 0.3993 & 0.0254 & 0.2389 & 0.0161 & 0.4512 & 0.0125 \\
\hline \multicolumn{15}{|l|}{$\theta$} \\
\hline \multicolumn{15}{|l|}{ Time shifters, $\lambda_{2,1994}=1$} \\
\hline$\lambda_{2,1995}$ & 0.4531 & 0.1298 & 0.2591 & 0.0373 & 0.4936 & 0.0756 & 0.2941 & 0.0226 & 0.2517 & 0.0739 & 1 & & 0.8214 & 0.0418 \\
\hline$\lambda_{2,1996}$ & 0.3801 & 0.1088 & 0.2477 & 0.0382 & 0.4839 & 0.0771 & 0.2396 & 0.0181 & 0.1703 & 0.0504 & 1.9774 & 0.1487 & 0.8135 & 0.0475 \\
\hline$\lambda_{2,1997}$ & 0.3480 & 0.1008 & 0.2497 & 0.0375 & 0.4839 & 0.0756 & 0.2677 & 0.0202 & 0.1963 & 0.0572 & 1.4402 & 0.1377 & 0.7179 & 0.0406 \\
\hline$\lambda_{2,1998}$ & 0.3511 & 0.1013 & 0.2187 & 0.0326 & 0.3287 & 0.0505 & 0.2784 & 0.0209 & 0.2373 & 0.0676 & 1.0818 & 0.0915 & 0.7025 & 0.0359 \\
\hline$\lambda_{2,1999}$ & 0.3886 & 0.1121 & 0.2923 & 0.0428 & 0.3875 & 0.0605 & 0.3371 & 0.0255 & 0.2284 & 0.0650 & 1.2422 & 0.1019 & 0.7140 & 0.0377 \\
\hline$\lambda_{2,2000}$ & 0.2918 & 0.0841 & 0.2838 & 0.0420 & 0.4541 & 0.0710 & 0.2704 & 0.0201 & 0.2432 & 0.0696 & 1.3644 & 0.1127 & 0.8482 & 0.0482 \\
\hline$\lambda_{2,2001}$ & 0.3957 & 0.1147 & 0.2566 & 0.0380 & 0.5629 & 0.0877 & 0.3255 & 0.0257 & 0.2346 & 0.0675 & 1.4003 & 0.1195 & 0.7977 & 0.0453 \\
\hline \multicolumn{15}{|l|}{ Cohort shifters, $\gamma_{2,40-50}=1$} \\
\hline$\gamma_{2,51-60}$ & 0.9547 & 0.0299 & 1.1306 & 0.0269 & 1.0459 & 0.0294 & 1.0555 & 0.0189 & 0.9383 & 0.0293 & 0.8573 & 0.0355 & 0.8949 & 0.0171 \\
\hline$\gamma_{2,61-70}$ & 0.9643 & 0.0268 & 1.1604 & 0.0228 & 1.1180 & 0.0313 & 0.9996 & 0.0140 & 1.0469 & 0.0303 & 1.0445 & 0.0429 & 0.9938 & 0.0182 \\
\hline$\gamma_{2,71-80}$ & 1.3832 & 0.0411 & 1.8221 & 0.0340 & 1.7278 & 0.0464 & 1.3569 & 0.0233 & 1.5123 & 0.0465 & 1.4318 & 0.0595 & 1.1898 & 0.0224 \\
\hline SSR & 0.0143 & & 0.0068 & & 0.0099 & & 0.0047 & & 0.0240 & & 0.0222 & & 0.0061 & \\
\hline$\chi^{2}$ & 2473.7073 & & 5710.0156 & & 2492.7787 & & 17769.4 & & 1756.357 & & 1632.232 & & 2597.3157 & \\
\hline $\log L$ & 459.2576 & & 513.2610 & & 486.0084 & & 540.040 & & 421.9693 & & 318.4753 & & 520.5053 & \\
\hline
\end{tabular}

Note: The SE column reports the standard error for the parameter estimate. Where I report the exp(estimate), the SE corresponds to the $\log (\exp ($ estimate $))$

$$
=
$$
estimate 
Table 6. Error-Components Models for Log Real Hourly Earnings (continued)

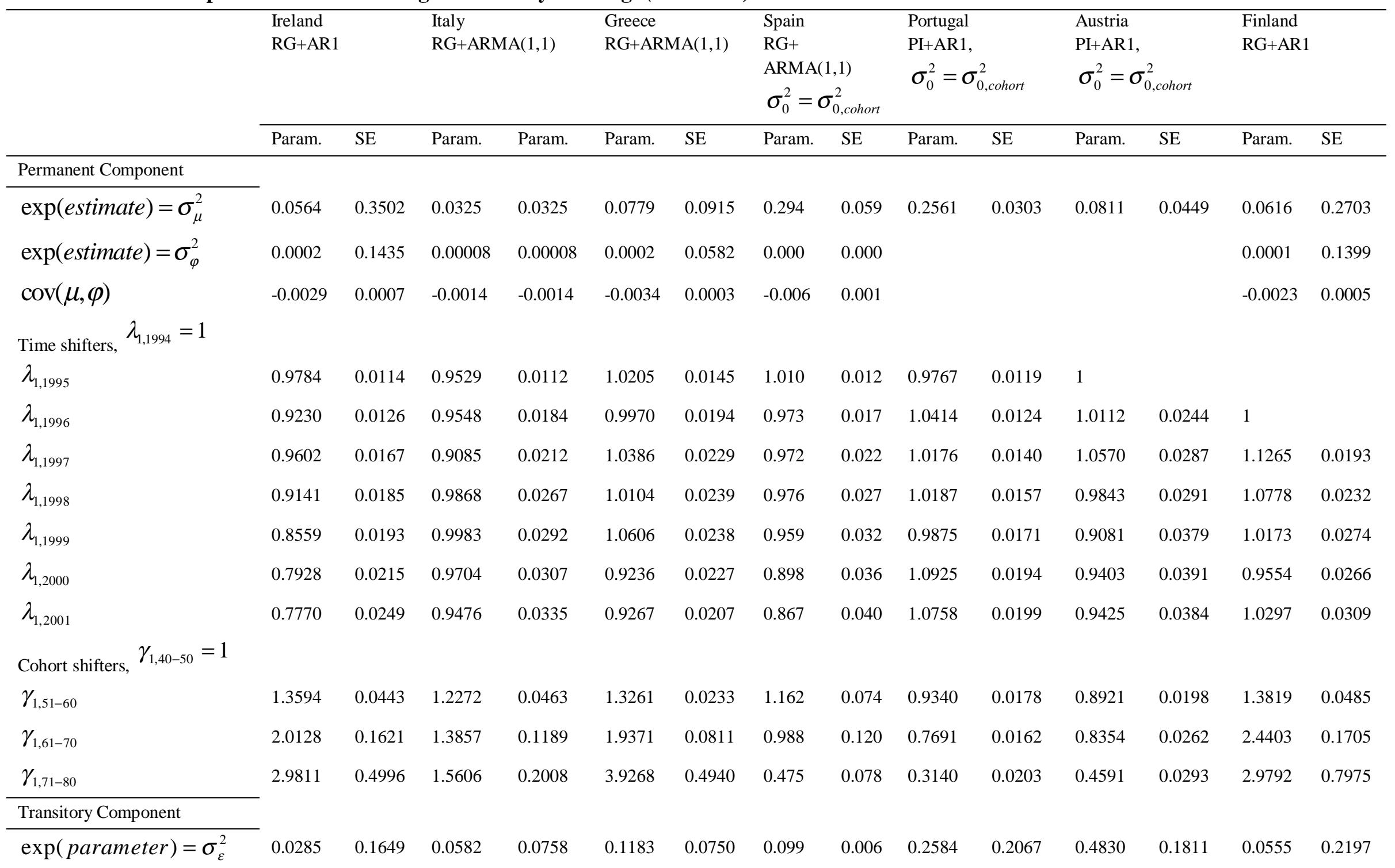




\begin{tabular}{|c|c|c|c|c|c|c|c|c|c|c|c|c|c|c|}
\hline \multicolumn{7}{|l|}{$\exp ($ estimate $)=\sigma_{0}^{2}$} & \multirow[t]{2}{*}{0.052} & \multirow[t]{2}{*}{0.004} & \multirow[t]{2}{*}{0.0428} & \multirow[t]{2}{*}{0.0974} & \multirow[t]{2}{*}{0.0751} & \multirow[t]{2}{*}{0.0652} & \multirow[b]{2}{*}{0.0550} & \multirow[b]{2}{*}{0.0743} \\
\hline $\exp ($ estimate $)=\sigma_{0,40-50}^{2}$ & 0.0709 & 0.0825 & 0.0314 & 0.0898 & 0.0791 & 0.0516 & & & & & & & & \\
\hline $\exp ($ estimate $)=\sigma_{0,51-60}^{2}$ & 0.0688 & 0.0966 & 0.0422 & 0.0619 & 0.0574 & 0.0702 & & & & & & & 0.0588 & 0.0701 \\
\hline $\exp ($ estimate $)=\sigma_{0,61-70}^{2}$ & 0.0942 & 0.0869 & 0.0521 & 0.0592 & 0.1011 & 0.0436 & & & & & & & 0.0707 & 0.0727 \\
\hline $\exp ($ estimate $)=\sigma_{0,71-80}^{2}$ & 0.0801 & 0.1015 & 0.0283 & 0.0919 & 0.0695 & 0.1269 & & & & & & & 0.0464 & 0.1098 \\
\hline$\rho$ & 0.2912 & 0.0229 & 0.6438 & 0.0428 & 0.5995 & 0.0346 & 0.849 & 0.024 & 0.7785 & 0.0149 & 0.7009 & 0.0292 & 0.2904 & 0.0195 \\
\hline$\theta$ & & & -0.2506 & 0.0204 & -0.1487 & 0.0242 & -0.364 & 0.007 & & & & & & \\
\hline \multicolumn{15}{|l|}{ Time shifters, $\lambda_{2,1994}=1$} \\
\hline$\lambda_{2,1995}$ & 1.2269 & 0.0938 & 0.7692 & 0.0239 & 0.7991 & 0.0261 & 0.907 & 0.027 & 0.5061 & 0.0525 & 1 & & & \\
\hline$\lambda_{2,1996}$ & 1.2789 & 0.1050 & 0.8238 & 0.0294 & 0.6992 & 0.0277 & 0.815 & 0.024 & 0.3117 & 0.0367 & 0.2929 & 0.0291 & 1 & \\
\hline$\lambda_{2,1997}$ & 1.0434 & 0.0818 & 0.7296 & 0.0241 & 0.6171 & 0.0280 & 0.842 & 0.024 & 0.3536 & 0.0383 & 0.2089 & 0.0224 & 0.8849 & 0.0977 \\
\hline$\lambda_{2,1998}$ & 1.0924 & 0.0853 & 0.7536 & 0.0264 & 0.6269 & 0.0275 & 0.887 & 0.023 & 0.3723 & 0.0397 & 0.1724 & 0.0196 & 0.7069 & 0.0809 \\
\hline$\lambda_{2,1999}$ & 1.0595 & 0.0821 & 0.6516 & 0.0242 & 0.6106 & 0.0256 & 0.760 & 0.021 & 0.3555 & 0.0371 & 0.2270 & 0.0223 & 0.9301 & 0.0957 \\
\hline$\lambda_{2,2000}$ & 1.0816 & 0.0876 & 0.6656 & 0.0225 & 0.7195 & 0.0287 & 0.821 & 0.022 & 0.3484 & 0.0362 & 0.2203 & 0.0220 & 0.8191 & 0.0861 \\
\hline$\lambda_{2,2001}$ & 1.1093 & 0.0968 & 0.6998 & 0.0234 & 0.6657 & 0.0287 & 0.856 & 0.023 & 0.3921 & 0.0400 & 0.2248 & 0.0229 & 0.7937 & 0.0852 \\
\hline \multicolumn{15}{|l|}{ Cohort shifters, $\gamma_{2,40-50}=1$} \\
\hline$\gamma_{2,51-60}$ & 0.9889 & 0.0352 & 0.9894 & 0.0204 & 0.9608 & 0.0179 & 1.004 & 0.025 & 0.7800 & 0.0383 & 0.8410 & 0.0254 & 0.8609 & 0.0253 \\
\hline$\gamma_{2,61-70}$ & 1.0987 & 0.0403 & 1.0324 & 0.0217 & 1.0187 & 0.0183 & 1.051 & 0.025 & 1.0102 & 0.0399 & 0.8986 & 0.0280 & 0.8714 & 0.0252 \\
\hline$\gamma_{2,71-80}$ & 1.1532 & 0.0458 & 1.3299 & 0.0278 & 0.9443 & 0.0256 & 1.330 & 0.030 & 1.1072 & 0.0409 & 1.1979 & 0.0416 & 1.2070 & 0.0349 \\
\hline SSR & 0.0273 & & 0.0017 & & 0.0146 & & 0.0094 & & 0.0288 & & 0.0052 & & 0.0038 & \\
\hline$\chi^{2}$ & 2116.2117 & & 1576.2281 & & 3824.4496 & & 1984.9587 & & 3737.5070 & & 2229.2852 & & 945.1045 & \\
\hline $\log L$ & 412.7881 & & 611.7874 & & 458.0054 & & 489.8478 & & 408.9498 & & 399.6179 & & 300.6177 & \\
\hline
\end{tabular}

Note: SE column reports the standard error for the parameter estimate. Where I report the exp(estimate), the SE corresponds to the $\log (\exp (\operatorname{estimate}))$ 
Table 7. Summary of the evolution of the actual inequality, permanent and transitory inequality, the permanent inequality as $\%$ of predicted overall variance, and the immobility ratio, by cohorts: 1994-2001

\begin{tabular}{|c|c|c|c|c|c|c|c|c|c|}
\hline & & & & & PV & & & & Luxembourg (the oldest three cohorts), \\
\hline & & Netherlands, & & & $\uparrow$ & & $\downarrow$ & component as & Greece, \\
\hline & & $\begin{array}{l}\text { Greece, } \\
\text { Portugal, } \\
\text { Finland (the oldest } \\
\text { three cohorts), } \\
\text { Italy, } \\
\text { Germany (the oldest } \\
\text { and the second }\end{array}$ & & $\uparrow$ & $\begin{array}{l}\text { Netherlands (the oldest } t \\
\text { cohorts) } \\
\text { Luxembourg (the young } \\
\text { Greece (the second olde } \\
\text { Portugal, } \\
\text { Italy (the youngest coho } \\
\text { Germany (the oldest and }\end{array}$ & $\begin{array}{l}\text { cohort), } \\
\text { ohort) }\end{array}$ & $\begin{array}{l}\text { Netherlands (the } \\
\text { youngest two } \\
\text { cohorts) } \\
\text { Belgium (the } \\
\text { youngest cohort), } \\
\text { Spain (the oldest } \\
\text { and the youngest }\end{array}$ & $\begin{array}{l}\% \\
\text { of overall } \\
\text { variance } \\
\text { increased } \\
\text { Û } \\
\text { Immobility } \\
\text { Increased }\end{array}$ & $\begin{array}{l}\text { Italy, } \\
\text { Germany (the second youngest cohort), } \\
\text { France (the second youngest cohort), } \\
\text { UK(the second youngest cohort), }\end{array}$ \\
\hline & & $\begin{array}{l}\text { youngest cohort), } \\
\text { France (the second }\end{array}$ & TV & & (the second youngest col & ) & youngest cohort) & Permanent & Netherlands, \\
\hline $\begin{array}{l}\text { Actual } \\
\text { Inequality }\end{array}$ & & $\begin{array}{l}\text { youngest cohort), } \\
\text { Belgium (the youngest } \\
\text { cohort), } \\
\text { UK(the youngest two } \\
\text { cohorts), } \\
\text { Spain (the oldest and } \\
\text { the youngest cohort) }\end{array}$ & & $\downarrow$ & $\begin{array}{l}\text { Luxembourg (the oldest } \\
\text { cohorts), } \\
\text { Italy (the oldest three co } \\
\text { Greece (the oldest and th } \\
\text { two cohorts) } \\
\text { Finland (the oldest three } \\
\text { UK (the second younges }\end{array}$ & $\begin{array}{l}\text { ts), } \\
\text { oungest } \\
\text { horts) } \\
\text { hort) }\end{array}$ & & $\begin{array}{l}\% \\
\text { of overall } \\
\text { variance } \\
\text { decreased } \\
\hat{U} \\
\text { Immobility } \\
\text { Decreased }\end{array}$ & $\begin{array}{l}\text { Portugal, } \\
\text { Luxembourg (the youngest cohort), } \\
\text { Germany (the oldest cohort), } \\
\text { Belgium (the youngest cohort), } \\
\text { UK(the youngest cohort), } \\
\text { Spain (the oldest and the youngest cohort) }\end{array}$ \\
\hline & & Denmark, & & & PV & & & & \\
\hline & & Germany (the second & & & $\uparrow$ & $\downarrow$ & & Permanent & Denmark (the second youngest cohort), \\
\hline & & $\begin{array}{l}\text { oldest and the } \\
\text { youngest cohort), } \\
\text { France (the oldest two } \\
\text { and the youngest } \\
\text { cohort), }\end{array}$ & & $\uparrow$ & & $\begin{array}{l}\text { Denma } \\
\text { cohort) } \\
\text { Belgiuı } \\
\text { Spain ( }\end{array}$ & $\begin{array}{l}\text { (the second oldest } \\
\text { (the middle cohorts), } \\
\text { le middle cohorts) }\end{array}$ & $\begin{array}{l}\text { component as } \\
\text { variance } \\
\text { increased } \\
\hat{U}\end{array}$ & $\begin{array}{l}\text { Germany (the second oldest and the } \\
\text { youngest cohort), } \\
\text { France (the oldest two and the youngest } \\
\text { cohort), } \\
\text { Belgium (the oldest cohort), }\end{array}$ \\
\hline & $\downarrow$ & $\begin{array}{l}\text { Belgium (the oldest } \\
\text { three cohorts), }\end{array}$ & & & & Denma & (the oldest and the & Increased & Ireland, Austria \\
\hline & & $\begin{array}{l}\text { UK(the oldest two } \\
\text { cohorts), } \\
\text { Ireland, } \\
\text { Austria, } \\
\text { Spain (the middle } \\
\text { cohorts), } \\
\text { Finland (the youngest } \\
\text { cohort) }\end{array}$ & TV & $\downarrow$ & $\begin{array}{l}\text { cohort), France (the } \\
\text { oldest two and the } \\
\text { youngest cohort), UK } \\
\text { (the second oldest } \\
\text { cohort), Ireland ( the } \\
\text { youngest three cohorts) }\end{array}$ & $\begin{array}{l}\text { younge } \\
\text { Germat } \\
\text { cohort) } \\
\text { cohort) } \\
\text { cohort) } \\
\text { cohort) } \\
\text { younge }\end{array}$ & $\begin{array}{l}\text { two cohorts), } \\
\text { (the second oldest } \\
\text { Belgium (the oldest } \\
\text { UK (the oldest } \\
\text { Ireland (the oldest } \\
\text { Austria, Finland (the } \\
\text { cohort) }\end{array}$ & $\begin{array}{l}\text { Permanent } \\
\text { component as } \\
\% \text { of overall } \\
\text { variance } \\
\text { decreased } \\
\hat{U} \\
\text { Immobility } \\
\text { Decreased }\end{array}$ & $\begin{array}{l}\text { Denmark (the oldest two and the youngest } \\
\text { cohort), } \\
\text { Belgium (the middle cohorts), } \\
\text { Spain (the middle cohorts), } \\
\text { Finland (the youngest cohort) }\end{array}$ \\
\hline
\end{tabular}


Table 8. Summary of the evolution of the average actual inequality, average permanent and transitory inequality, and the average immobility ratio : 1994-2001

\begin{tabular}{|c|c|c|c|c|c|c|c|c|c|}
\hline \multirow{9}{*}{$\begin{array}{l}\text { Average } \\
\text { Actual } \\
\text { Inequality }\end{array}$} & \multirow{4}{*}{ Increased } & \multirow{4}{*}{$\begin{array}{l}\text { Netherlands, } \\
\text { Luxembourg, } \\
\text { Greece, } \\
\text { Portugal, } \\
\text { Finland, } \\
\text { Italy }\end{array}$} & & & Average Perm & t Inequality & \multirow{4}{*}{$\begin{array}{l}\text { Average } \\
\text { Permanent } \\
\text { Inequality as } \\
\% \text { of } \\
\text { Average } \\
\text { Inequality }\end{array}$} & \multirow{3}{*}{$\begin{array}{l}\text { Increased } \\
\hat{U} \\
\text { Average Immobility } \\
\text { Increased }\end{array}$} & \multirow{3}{*}{$\begin{array}{l}\text { Luxembourg, } \\
\text { Greece, } \\
\text { Finland, } \\
\text { Italy }\end{array}$} \\
\hline & & & & & Increased & Decreased & & & \\
\hline & & & \multirow{2}{*}{$\begin{array}{l}\text { Average } \\
\text { Transitory } \\
\text { Inequality }\end{array}$} & Increased & $\begin{array}{l}\text { Netherlands, } \\
\text { Portugal }\end{array}$ & & & & \\
\hline & & & & Decreased & $\begin{array}{l}\text { Luxembourg, } \\
\text { Greece, } \\
\text { Finland, } \\
\text { Italy }\end{array}$ & & & $\begin{array}{l}\text { Decreased } \\
\hat{U} \\
\text { Average Immobility } \\
\text { Decreased }\end{array}$ & $\begin{array}{l}\text { Netherlands, } \\
\text { Portugal }\end{array}$ \\
\hline & \multirow{5}{*}{ Decreased: } & \multirow{5}{*}{$\begin{array}{l}\text { Denmark, } \\
\text { Germany, } \\
\text { France, } \\
\text { Belgium, } \\
\text { UK, } \\
\text { Ireland, } \\
\text { Austria, } \\
\text { Spain }\end{array}$} & & & \multicolumn{2}{|c|}{ Average Permanent Inequality } & \multirow{5}{*}{$\begin{array}{l}\text { Average } \\
\text { Permanent } \\
\text { Inequality as } \\
\% \text { of } \\
\text { Average } \\
\text { Inequality }\end{array}$} & \multirow{3}{*}{$\begin{array}{l}\text { Increased } \\
\hat{U} \\
\text { Average Immobility } \\
\text { Increased }\end{array}$} & \multirow{3}{*}{$\begin{array}{l}\text { Germany, } \\
\text { France, } \\
\text { UK, } \\
\text { Ireland, } \\
\text { Austria }\end{array}$} \\
\hline & & & & & Increased & Decreased & & & \\
\hline & & & \multirow{3}{*}{$\begin{array}{l}\text { Average } \\
\text { Transitory } \\
\text { Inequality }\end{array}$} & Increased & & $\begin{array}{l}\text { Belgium, } \\
\text { Spain }\end{array}$ & & & \\
\hline & & & & & & & & Decreased & Denmark, \\
\hline & & & & Decreased & $\begin{array}{l}\text { Germany, } \\
\text { France, UK, } \\
\text { Ireland }\end{array}$ & $\begin{array}{l}\text { Denmark, } \\
\text { Austria }\end{array}$ & & $\begin{array}{l}\hat{U} \\
\text { Average Immobility } \\
\text { Decreased }\end{array}$ & $\begin{array}{l}\text { Belgium, } \\
\text { Spain, }\end{array}$ \\
\hline
\end{tabular}


Table 9. Pair wise Correlations Between the Labour Market Outcomes, Labour Market Institutional Factors and Macroeconomic Shocks

\begin{tabular}{|c|c|c|c|c|c|c|}
\hline \multirow{3}{*}{ Pair wise Correlations } & \multicolumn{2}{|c|}{ Permanent Variance } & \multicolumn{2}{|c|}{ Temporary Variance } & \multicolumn{2}{|c|}{ Immobility (PV/TV) } \\
\hline & Cohort & Cohort & Cohort & Cohort & Cohort & Cohort \\
\hline & $1940-1969$ & 1981 & $1940-1969$ & $1970-1981$ & 1940-1969 & $\begin{array}{l}1970- \\
1981\end{array}$ \\
\hline \multirow{2}{*}{ EPL } & 0.313 & -0.245 & 0.207 & 0.166 & 0.140 & -0.317 \\
\hline & 0.000 & 0.014 & 0.000 & 0.096 & 0.015 & 0.001 \\
\hline \multirow{2}{*}{ EPL regular contracts (EPLR) } & 0.488 & -0.171 & 0.190 & 0.259 & 0.225 & -0.263 \\
\hline & 0.000 & 0.087 & 0.001 & 0.009 & 0.000 & 0.008 \\
\hline \multirow{2}{*}{ EPL temporary contracts (EPLT) } & 0.122 & -0.213 & 0.158 & 0.070 & 0.051 & -0.254 \\
\hline & 0.034 & 0.032 & 0.006 & 0.488 & 0.380 & 0.010 \\
\hline \multirow{2}{*}{ [(EPLR-EPLT)/EPLT]*100 } & 0.116 & 0.555 & 0.086 & -0.147 & 0.024 & 0.593 \\
\hline & 0.041 & 0.000 & 0.135 & 0.142 & 0.674 & 0.000 \\
\hline \multirow{2}{*}{ Union Density } & -0.588 & -0.333 & -0.323 & -0.340 & -0.245 & -0.110 \\
\hline & 0.000 & 0.000 & 0.000 & 0.000 & 0.000 & 0.256 \\
\hline \multirow{2}{*}{ Degree of Corporatism } & -0.498 & -0.441 & -0.477 & -0.228 & -0.086 & -0.201 \\
\hline & 0.000 & 0.000 & 0.000 & 0.028 & 0.151 & 0.054 \\
\hline \multirow{2}{*}{ Tax Wedge } & -0.3 & -0.385 & -0.245 & 0.096 & -0.066 & -0.449 \\
\hline & 0.000 & 0.000 & 0.000 & 0.361 & 0.271 & 0.000 \\
\hline \multirow{2}{*}{ PMR } & 0.247 & 0.041 & 0.053 & 0.046 & 0.160 & 0.018 \\
\hline & 0.000 & 0.695 & 0.381 & 0.664 & 0.007 & 0.863 \\
\hline \multirow{2}{*}{ Active Labour Market Policies } & -0.267 & -0.219 & -0.240 & 0.150 & -0.063 & -0.184 \\
\hline & 0.000 & 0.035 & 0.000 & 0.151 & 0.294 & 0.077 \\
\hline \multirow{2}{*}{$\begin{array}{l}\text { Average Unemployment } \\
\text { Benefit Replacement Rate }\end{array}$} & -0.223 & -0.450 & -0.225 & 0.214 & -0.114 & -0.465 \\
\hline & 0.000 & 0.000 & 0.000 & 0.039 & 0.057 & 0.000 \\
\hline \multirow{2}{*}{ Labour Demand Shock } & 0.177 & 0.605 & 0.021 & 0.005 & 0.066 & 0.574 \\
\hline & 0.005 & 0.000 & 0.742 & 0.966 & 0.291 & 0.000 \\
\hline \multirow{2}{*}{ Terms of Trade Shock } & -0.03 & 0.151 & -0.061 & -0.068 & 0.105 & 0.102 \\
\hline & 0.623 & 0.149 & 0.314 & 0.520 & 0.080 & 0.330 \\
\hline \multirow{2}{*}{ Total Factor Production Shock } & -0.241 & -0.082 & -0.371 & -0.259 & -0.041 & 0.163 \\
\hline & 0.000 & 0.454 & 0.000 & 0.017 & 0.517 & 0.137 \\
\hline \multirow{2}{*}{ Real Interest Shock } & -0.148 & -0.134 & -0.010 & -0.011 & -0.056 & -0.218 \\
\hline & 0.013 & 0.200 & 0.875 & 0.918 & 0.352 & 0.036 \\
\hline \multirow{2}{*}{ Aggregate Supply Shock } & -0.104 & -0.075 & -0.007 & -0.008 & -0.014 & -0.103 \\
\hline & 0.071 & 0.456 & 0.903 & 0.934 & 0.805 & 0.308 \\
\hline \multirow{2}{*}{ Aggregate Demand Shock } & -0.208 & -0.156 & -0.237 & -0.236 & -0.092 & -0.003 \\
\hline & 0.000 & 0.121 & 0.000 & 0.017 & 0.111 & 0.977 \\
\hline
\end{tabular}

Note: $P$-values are reported in parenthesis. 
Table 10. Model 1 - Systemic Effects across Institutions

\begin{tabular}{|c|c|c|c|c|c|c|}
\hline & \multicolumn{2}{|c|}{ Permanent Variance } & \multicolumn{2}{|c|}{ Temporary Variance } & \multicolumn{2}{|c|}{ Wage Immobility } \\
\hline & $\begin{array}{l}\text { Parameter } \\
\text { Estimate }\end{array}$ & SE & $\begin{array}{l}\text { Parameter } \\
\text { Estimate }\end{array}$ & $\mathrm{SE}$ & $\begin{array}{l}\text { Parameter } \\
\text { Estimate }\end{array}$ & SE \\
\hline \multicolumn{7}{|l|}{ Systemic Interactions } \\
\hline EPL & $0.198 * * *$ & 0.061 & 0.026 & 0.019 & 0.112 & 0.073 \\
\hline Relative EPL & $0.098 * * *$ & 0.025 & 0.008 & 0.008 & -0.005 & 0.037 \\
\hline Union Density & $-1.201 * * *$ & 0.349 & -0.024 & 0.039 & $-1.566 * *$ & 0.530 \\
\hline Int. Corp. & $-0.892 * * *$ & 0.054 & $-0.538 * * *$ & 0.109 & $-1.166^{* * *}$ & 0.114 \\
\hline High Corp. & $-0.559 * * *$ & 0.112 & $-0.898 * * *$ & 0.066 & $-0.823 * * *$ & 0.070 \\
\hline Tax Wedge & $-1.462 * *$ & 0.588 & 0.070 & 0.072 & -0.718 & 0.744 \\
\hline PMR & $-0.069 * *$ & 0.024 & 0.004 & 0.009 & $0.181 * *$ & 0.069 \\
\hline ALMPs & 0.058 & 0.091 & 0.016 & 0.033 & $1.863^{* *}$ & 0.598 \\
\hline Unemployment Benefit & $1.074 * * *$ & 0.329 & $0.192 *$ & 0.111 & 0.712 & 0.434 \\
\hline \multicolumn{7}{|l|}{ Direct Effects } \\
\hline EPL & $0.080 * * *$ & 0.021 & 0.056 & 0.065 & $14.787 * *$ & 5.416 \\
\hline Relative EPL & $0.054 * * *$ & 0.008 & 0.022 & 0.018 & $3.173^{*}$ & 1.801 \\
\hline Union Density & $-0.335 * * *$ & 0.102 & -0.388 & 0.242 & $-17.637 * *$ & 8.613 \\
\hline Intermediate Corporatism & $0.307 * * *$ & 0.081 & -0.175 & 0.379 & $-6.448 *$ & 3.369 \\
\hline High Corporatism & $0.092 * * *$ & 0.026 & -0.986 & 0.845 & $13.095 * *$ & 4.463 \\
\hline Tax Wedge & $0.708 * * *$ & 0.117 & 0.248 & 0.152 & 28.619 & 18.631 \\
\hline PMR & 0.008 & 0.013 & $-0.084 * * *$ & 0.025 & 1.852 & 1.495 \\
\hline ALMPs & 0.014 & 0.037 & $0.321 *$ & 0.171 & $12.592 * *$ & 5.534 \\
\hline Unemployment Benefit & $-0.842 * * *$ & 0.252 & $0.756 * *$ & 0.367 & $-130.927 * *$ & 43.999 \\
\hline Cohort 1940-1950 & 1 & & 1 & & 1 & \\
\hline Cohort 1951-1960 & $0.886 * * *$ & 0.015 & $0.884 * * *$ & 0.046 & $0.651 * * *$ & 0.048 \\
\hline Cohort 1961-1970 & $0.621 * * *$ & 0.014 & $1.041 * * *$ & 0.050 & $0.386 * * *$ & 0.043 \\
\hline Cohort 1971-1980 & $0.205 * * *$ & 0.012 & $1.806 * * *$ & 0.071 & $0.082 * *$ & 0.041 \\
\hline 1994 & 1 & & 1 & & 1 & \\
\hline 1995 & $0.960 * * *$ & 0.032 & $0.729 * * *$ & 0.040 & $0.348 * * *$ & 0.055 \\
\hline 1996 & $0.976 * * *$ & 0.032 & $0.563 * * *$ & 0.036 & $0.546 * * *$ & 0.064 \\
\hline 1997 & $1.020 * * *$ & 0.034 & $0.505 * * *$ & 0.036 & $0.697 * * *$ & 0.085 \\
\hline 1998 & $0.980 * * *$ & 0.036 & $0.465 * * *$ & 0.035 & $0.677 * * *$ & 0.087 \\
\hline 1999 & $0.916 * * *$ & 0.040 & $0.436 * * *$ & 0.038 & $0.677 * * *$ & 0.104 \\
\hline 2000 & $0.893 * * *$ & 0.044 & $0.405 * * *$ & 0.037 & $0.786^{* * *}$ & 0.129 \\
\hline 2001 & $0.872 * * *$ & 0.046 & $0.424 * * *$ & 0.040 & $0.526 * * *$ & 0.102 \\
\hline Adj. R-squared & 0.978 & & 0.932 & & 0.716 & \\
\hline $\mathrm{N}$ & 372 & & 372 & & 372 & \\
\hline
\end{tabular}

Note: Estimated with non-linear least squares 
Table 11. Models with cross-interactions between institutions and macroeconomic shocks, and between institutions

\begin{tabular}{|c|c|c|c|c|c|c|c|c|c|c|c|c|}
\hline \multirow{3}{*}{$\begin{array}{c}\text { Labour } \\
\text { market factors } \\
\text { and } \\
\text { institutions }\end{array}$} & \multicolumn{6}{|c|}{$\begin{array}{c}\text { Model } 2 . \\
\text { Cross-interactions between institutions, and } \\
\text { between institutions and macroeconomic shocks }\end{array}$} & \multicolumn{6}{|c|}{\begin{tabular}{|c|} 
Model 3. \\
Specific interactions between institutions and shocks
\end{tabular}} \\
\hline & \multicolumn{2}{|c|}{$\begin{array}{c}\text { Permanent } \\
\text { Variance }\end{array}$} & \multicolumn{2}{|c|}{$\begin{array}{c}\text { Temporary } \\
\text { Variance }\end{array}$} & \multicolumn{2}{|c|}{$\begin{array}{c}\text { Wage } \\
\text { Immobility }\end{array}$} & \multicolumn{2}{|c|}{$\begin{array}{c}\text { Permanent } \\
\text { Variance }\end{array}$} & \multicolumn{2}{|c|}{$\begin{array}{l}\text { Temporary } \\
\text { Variance }\end{array}$} & \multicolumn{2}{|c|}{ Wage Immobility } \\
\hline & Est. & SE & Est. & SE & Est. & SE & Est. & SE & Est. & SE & Est. & SE \\
\hline \multicolumn{13}{|c|}{ Direct effects of institutions } \\
\hline EPL & $0.028 * * *$ & 0.006 & $0.011 * *$ & 0.004 & 0.437 & 0.874 & $-0.111 * * *$ & 0.013 & $0.186 * *$ & 0.081 & $92.057 * * *$ & 22.646 \\
\hline Relative EPL & $0.027 * * *$ & 0.002 & $0.012 * * *$ & 0.001 & $0.898 * * *$ & 0.223 & $-0.076^{* * *}$ & 0.011 & 0.007 & 0.005 & $-5.885^{* * *}$ & 1.406 \\
\hline Union Density & -0.010 & 0.014 & -0.001 & 0.009 & -3.881 & 2.656 & $0.666 * * *$ & 0.133 & 0.237 & 0.269 & $-14.649 * *$ & 4.904 \\
\hline Int. Corp. & $0.077 * * *$ & 0.011 & $0.037 * * *$ & 0.007 & 0.069 & 2.079 & $0.764 * * *$ & 0.108 & $-0.410 * *$ & 0.170 & $-179.828 * * *$ & $* 40.646$ \\
\hline High Corp. & $-0.045 * * *$ & 0.011 & $0.016^{* *}$ & 0.007 & 1.091 & 1.964 & $0.158 * *$ & 0.051 & $-0.298 *$ & 0.158 & $-168.413 * * ;$ & $* 39.556$ \\
\hline Tax Wedge & $0.111 * *$ & 0.040 & 0.019 & 0.026 & -0.746 & 7.023 & $-0.289 * * *$ & 0.088 & $-0.267 * * *$ & 0.059 & 47.965 & 51.584 \\
\hline PMR & -0.001 & 0.004 & $-0.011 * * *$ & 0.003 & 0.127 & 0.433 & $0.022 * * *$ & 0.004 & $-0.011 * * *$ & 0.003 & $-19.667 * *$ & 7.188 \\
\hline ALMPs & $0.061 *$ & 0.032 & -0.023 & 0.017 & -2.783 & 2.293 & $0.121 * * *$ & 0.035 & -0.007 & 0.016 & -6.193 & 7.571 \\
\hline Unempl. Ben. & 0.003 & 0.037 & $0.067 * *$ & 0.022 & $9.423 * *$ & 4.258 & $-0.208 * * *$ & 0.041 & -0.259 & 0.374 & $21.463 * *$ & 9.373 \\
\hline \multicolumn{13}{|c|}{ Interactions between Institutions } \\
\hline \multicolumn{7}{|c|}{ EPL*Relative EPL } & $-0.040 * * *$ & 0.007 & -0.003 & 0.004 & & \\
\hline \multicolumn{7}{|c|}{ EPL*Union Density } & & & -0.059 & 0.041 & $81.033 * * *$ & 12.866 \\
\hline \multicolumn{7}{|c|}{ EPL*Intermediate Corporatism } & & & $-0.243 * *$ & 0.082 & $-69.142 * * *$ & 21.388 \\
\hline \multicolumn{7}{|c|}{ EPL*High Corporatism } & & & $-0.155^{*}$ & 0.082 & $-105.246^{* * *}$ & $* 23.671$ \\
\hline \multicolumn{7}{|c|}{ EPL*Tax Wedge } & $0.367 * * *$ & 0.094 & $-0.290 * * *$ & 0.086 & 24.219 & 21.655 \\
\hline \multicolumn{7}{|l|}{ EPL*PMR } & & & 0.001 & 0.008 & $-8.419 * * *$ & 1.725 \\
\hline \multicolumn{7}{|l|}{ EPL*ALMPs } & & & $-0.055 * *$ & 0.026 & -7.589 & 10.205 \\
\hline \multicolumn{7}{|c|}{ EPL* Unemployment Benefit } & & & 0.014 & 0.048 & 3.152 & 14.398 \\
\hline \multicolumn{7}{|c|}{ Union Density* Intermediate Corporatism } & $1.348 * * *$ & 0.371 & $-0.934 * *$ & 0.361 & & \\
\hline \multicolumn{7}{|c|}{ Union Density $*$ High Corporatism } & $-0.941 * * *$ & 0.145 & -0.221 & 0.272 & & \\
\hline \multicolumn{7}{|c|}{ Union Density $*$ Tax Wedge } & $2.276 * * *$ & 0.501 & $0.654 *$ & 0.340 & $260.189 * *$ & 90.354 \\
\hline Union Density * & PMR & & & & & & $-0.053 * *$ & 0.023 & $0.058 * *$ & 0.019 & -4.670 & 4.770 \\
\hline Union Density * & ALMPs & & & & & & -0.159 & 0.144 & & & & \\
\hline Union Density * & Unemploy & yment I & Benefit RR & & & & & & & & & \\
\hline Tax Wedge * In & termediate & Corpol & ratism & & & & & & & & 45.070 & 58.520 \\
\hline Tax Wedge $*$ Hi & gh Corpora & atism & & & & & & & & & -88.375 & 58.709 \\
\hline Tax Wedge *PN & & & & & & & $-0.185^{* *}$ & 0.061 & & & & \\
\hline Tax Wedge *AL & MPs & & & & & & $1.610 * *$ & 0.785 & & & $-379.209 * *$ & 129.38 \\
\hline Tax Wedge $*$ Ur & nemployme & ent Ben & nefit & & & & $-4.379 * * *$ & 0.988 & $-1.029 * *$ & 0.479 & & \\
\hline $\mathrm{PMR} *$ Intermed & diate Corpo & oratism & & & & & & & & & $23.478 * *$ & 7.449 \\
\hline PMR *High Cor & rporatism & & & & & & & & & & $16.438 * *$ & 6.961 \\
\hline PMR *ALMPs & & & & & & & $-0.087 * * *$ & 0.022 & & & $15.667 * *$ & 5.126 \\
\hline PMR * Unemplc & oyment Bel & nefit & & & & & $0.329 * * *$ & 0.047 & & & $-34.293 * * *$ & 8.2 \\
\hline ALMPs * Intern & nediate Cor & rporatis & & & & & & & & & & \\
\hline ALMPs *High $\mathrm{C}$ & Corporatisn & & & & & & & & & & & \\
\hline ALMPs * Unem & aployment I & Benefit & & & & & -0.445 & 0.310 & & & $293.951 * * *$ & * 62.901 \\
\hline Unemployment & Benefit *In & ntermec & diate Corpo & ratism & & & & & 0.462 & 0.397 & & \\
\hline Unemployment & Benefit $* H$ & High $\mathrm{Co}$ & orporatism & & & & & & 0.274 & 0.379 & & \\
\hline
\end{tabular}




\begin{tabular}{|c|c|c|c|c|c|c|c|c|c|c|c|c|}
\hline \multicolumn{13}{|c|}{ Direct effects of shocks } \\
\hline $\begin{array}{l}\text { Aggregate } \\
\text { Supply Shock }\end{array}$ & -0.0003 & 0.002 & $0.006 * *$ & 0.002 & -0.19 & 0.416 & & & 0.0003 & 0.005 & 1.106 & 0.906 \\
\hline $\begin{array}{l}\text { Aggregate } \\
\text { Demand Shock }\end{array}$ & $0.007 * *$ & 0.003 & $-0.009 * *$ & 0.003 & $-1.53 * *$ & 0.622 & & & -0.0002 & 0.004 & $-8.963 * * *$ & 1.484 \\
\hline $\begin{array}{l}\text { Labour } \\
\text { Demand Shock }\end{array}$ & 0.017 & 0.079 & $-0.142 * *$ & 0.063 & $\begin{array}{c}-139.51 \\
* * *\end{array}$ & 40.93 & 0.253 & 0.232 & 0.005 & 0.078 & $-386.792 * * *$ & *60.692 \\
\hline $\begin{array}{l}\text { Terms of Trade } \\
\text { Shock }\end{array}$ & $-1.054 * * *$ & 0.292 & $0.398 * *$ & 0.155 & $\begin{array}{c}202.302 \\
* * *\end{array}$ & 53.47 & -0.166 & 0.155 & -0.0005 & 0.007 & $726.740 * * *$ & 118.68 \\
\hline $\begin{array}{l}\text { TF Production } \\
\text { Shock }\end{array}$ & 0.205 & 0.249 & $0.217 * *$ & 0.091 & $\begin{array}{c}175.117 \\
* *\end{array}$ & 73.99 & -0.033 & 0.049 & 0.007 & 0.106 & $144.281 *$ & 80.708 \\
\hline $\begin{array}{l}\text { Interest Rate } \\
\text { Shock }\end{array}$ & -0.095 & 0.243 & $-0.471 * *$ & 0.180 & $\begin{array}{c}-346.24 \\
* * *\end{array}$ & 100.56 & -0.026 & 0.044 & -0.005 & 0.081 & $\begin{array}{c}-1042.999 \\
* * *\end{array}$ & 147.86 \\
\hline \multicolumn{13}{|c|}{ Interactions between institutions and shocks } \\
\hline EPL & $0.483 * * *$ & 0.119 & -0.131 & 0.288 & $0.587 * * *$ & 0.114 & -0.311 & 0.480 & 14.189 & 220.044 & $0.475 * * *$ & 0.079 \\
\hline Relative EPL & $0.345 * * *$ & 0.093 & -0.128 & 0.128 & -0.003 & 0.062 & & & 1.266 & 19.637 & -0.032 & 0.036 \\
\hline Union Density & $2.005 * * *$ & 0.535 & -0.446 & 0.595 & $1.060 * * *$ & 0.281 & 5.731 & 5.643 & -79.468 & 1236.53 & $1.153 * * *$ & 0.159 \\
\hline $\begin{array}{l}\text { Intermediate } \\
\text { Corporatism }\end{array}$ & $-0.420 * *$ & 0.187 & 0.008 & 0.368 & $\begin{array}{c}-1.061 \\
* * *\end{array}$ & 0.159 & 7.685 & 8.505 & 77.631 & 1221.39 & $-0.730 * * *$ & 0.066 \\
\hline $\begin{array}{l}\text { High } \\
\text { Corporatism }\end{array}$ & $-1.646 * * *$ & 0.187 & $\begin{array}{c}-0.668 \\
* * *\end{array}$ & 0.133 & $\begin{array}{l}-0.622 \\
* * *\end{array}$ & 0.118 & $-1.948^{*}$ & 1.008 & 26.103 & 421.66 & $-0.864 * * *$ & 0.030 \\
\hline Tax Wedge & $3.597 * *$ & 1.627 & $-3.093^{*}$ & 1.782 & $-4.682 * *$ & 1.853 & 2.822 & 4.206 & -205.500 & 3197.89 & $-3.664 * * *$ & 0.680 \\
\hline PMR & $0.206^{* *}$ & 0.080 & $0.595^{* *}$ & 0.205 & $0.162 * *$ & 0.065 & -0.056 & 0.256 & -1.025 & 16.072 & $0.097 * * *$ & 0.029 \\
\hline ALMPs & -0.139 & 0.344 & $1.362 * *$ & 0.647 & $1.029 * *$ & 0.444 & -3.350 & 4.755 & -4.938 & 82.823 & $2.136 * * *$ & 0.293 \\
\hline $\begin{array}{l}\text { Unemployment } \\
\text { Benefit }\end{array}$ & $1.783 * *$ & 0.697 & $-2.015^{*}$ & 1.214 & $-1.423^{*}$ & 0.796 & 7.987 & 7.320 & -37.678 & 593.17 & $-2.036 * * *$ & 0.328 \\
\hline \multicolumn{13}{|c|}{ Controls - cohort level } \\
\hline \multicolumn{7}{|c|}{ Proportion of university degree } & & & & & 0.165 & 0.787 \\
\hline \multicolumn{7}{|c|}{ Proportion of upper-secondary degree } & & & & & 0.236 & 0.564 \\
\hline \multicolumn{7}{|c|}{ Proportion of private employees } & $-0.019 * *$ & 0.007 & 0.013 & 0.012 & $-1.695 * *$ & 0.691 \\
\hline \multicolumn{7}{|c|}{ Proportion of permanent contracts } & $0.034 * * *$ & 0.007 & 0.004 & 0.009 & 0.953 & 0.702 \\
\hline \multicolumn{13}{|c|}{ Proportion of unemployed } \\
\hline \multicolumn{7}{|c|}{ Occ 1} & $0.132 * * *$ & 0.038 & & & $7.986 * * *$ & 2.456 \\
\hline \multicolumn{7}{|l|}{ Occ 2} & $0.050 *$ & 0.028 & & & & \\
\hline \multicolumn{7}{|l|}{ Occ 3} & $-0.052 *$ & 0.029 & & & & \\
\hline \multicolumn{13}{|l|}{ Occ 4} \\
\hline \multicolumn{13}{|l|}{ Occ 5} \\
\hline \multicolumn{7}{|l|}{ Occ 6} & & & & & 8.249 & 5.765 \\
\hline \multicolumn{7}{|l|}{ Occ 7} & $-0.059 * * *$ & 0.016 & 0.024 & 0.025 & & \\
\hline \multicolumn{7}{|l|}{ Occ 8} & & & -0.044 & 0.039 & $9.059 * *$ & 4.145 \\
\hline \multicolumn{7}{|l|}{ Occ 9} & & & 0.060 & 0.044 & 4.681 & 3.452 \\
\hline \multicolumn{13}{|l|}{ Cohort Shifters } \\
\hline $1940-1950$ & 1 & & 1 & & 1 & & 1 & & 1 & & 1 & \\
\hline $1951-1960$ & $0.882 * * *$ & 0.016 & $0.935 * * *$ & 0.054 & $0.589 * * *$ & 0.052 & $0.869 * * *$ & 0.016 & $0.862 * * *$ & 0.078 & $0.159 * * *$ & 0.043 \\
\hline 1961-1970 & $0.619 * * *$ & 0.014 & $1.040 * * *$ & 0.057 & $0.376^{* * *}$ & 0.048 & $0.599 * * *$ & 0.017 & $0.954 * * *$ & 0.099 & $0.086^{* *}$ & 0.044 \\
\hline 1971-1980 & $0.242 * * *$ & 0.012 & $1.917 * * *$ & 0.086 & $0.081 *$ & 0.045 & $0.218 * * *$ & 0.022 & $2.267 * * *$ & 0.248 & 0.016 & 0.045 \\
\hline \multicolumn{3}{|l|}{${\text { Adjuster } \mathrm{R}^{2}}$} & \multicolumn{2}{|c|}{0.929} & \multicolumn{2}{|c|}{0.689} & \multicolumn{2}{|c|}{0.989} & \multicolumn{2}{|c|}{0.942} & 0.806 & \\
\hline $\mathrm{N}$ & 320 & & 320 & & 320 & & 320 & & 320 & 20 & 320 & \\
\hline
\end{tabular}


Table 12. Summary results for permanent variance

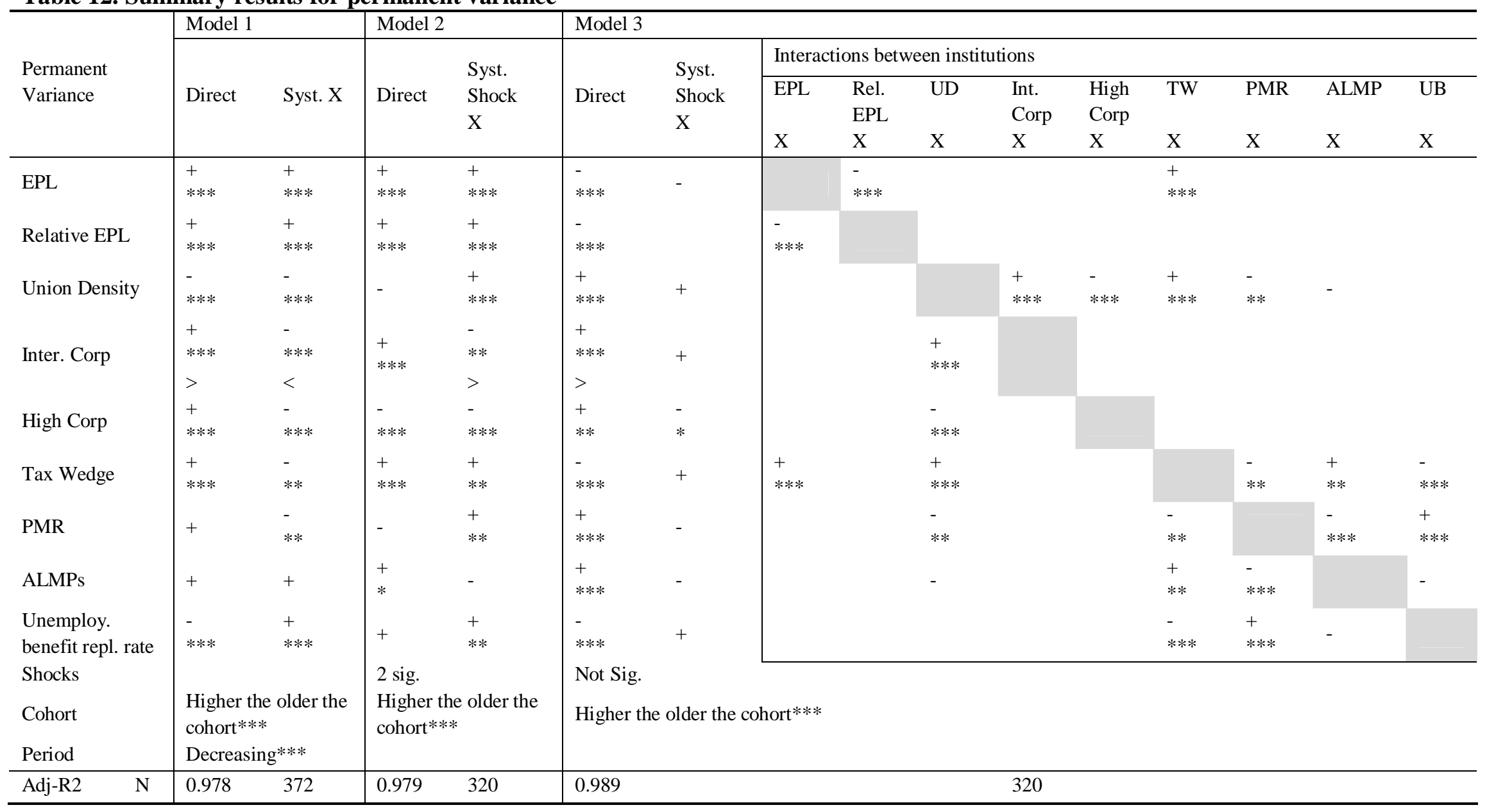


Table 13. Summary results for transitory variance

\begin{tabular}{|c|c|c|c|c|c|c|c|c|c|c|c|c|c|c|c|}
\hline \multirow{3}{*}{$\begin{array}{l}\text { Transitory } \\
\text { Variance }\end{array}$} & \multicolumn{2}{|c|}{ Model 1} & \multicolumn{2}{|c|}{ Model 2} & \multicolumn{11}{|c|}{ Model 3} \\
\hline & \multirow[b]{2}{*}{ Direct } & \multirow[b]{2}{*}{ Syst. X } & \multirow[b]{2}{*}{ Direct } & \multirow{2}{*}{$\begin{array}{l}\text { Syst. } \\
\text { Shock } \\
\text { X }\end{array}$} & \multirow[b]{2}{*}{ Direct } & \multirow[b]{2}{*}{$\begin{array}{l}\text { Syst. } \\
\text { Shock } \\
\text { X }\end{array}$} & \multicolumn{9}{|c|}{ Interactions between institutions } \\
\hline & & & & & & & $\begin{array}{l}\text { EPL } \\
X\end{array}$ & $\begin{array}{l}\text { Rel. } \\
\text { EPL } \\
X\end{array}$ & & $\begin{array}{l}\text { Int. } \\
\text { Corp } \\
\mathrm{X}\end{array}$ & $\begin{array}{l}\text { High } \\
\text { Corp } \\
\mathrm{X}\end{array}$ & $\begin{array}{l}\text { TW } \\
X\end{array}$ & $\begin{array}{l}\text { PMR } \\
\mathrm{X}\end{array}$ & $\begin{array}{l}\text { ALMP } \\
\mathrm{X}\end{array}$ & $\begin{array}{l}\text { UB } \\
\mathrm{X}\end{array}$ \\
\hline EPL & + & + & & - & $\begin{array}{l}+ \\
* *\end{array}$ & + & & - & - & $\begin{array}{l}- \\
* * \\
<\end{array}$ & - & $\begin{array}{l}- \\
* * *\end{array}$ & + & $\begin{array}{l}- \\
* *\end{array}$ & + \\
\hline Relative EPL & + & + & $\begin{array}{l}+ \\
* * *\end{array}$ & - & + & + & - & & & & & & & & \\
\hline Union Density & - & - & - & - & + & - & - & & & $\begin{array}{l}- \\
* *\end{array}$ & - & $\begin{array}{l}+ \\
*\end{array}$ & $\begin{array}{l}+ \\
* *\end{array}$ & & \\
\hline Inter. Corp & - & $\begin{array}{l}- \\
* * * \\
>\end{array}$ & $\begin{array}{l}+ \\
* * * \\
>\end{array}$ & + & $\begin{array}{l}- \\
* * \\
<\end{array}$ & + & $\begin{array}{l}- \\
* * \\
<\end{array}$ & & $\begin{array}{l}- \\
* *\end{array}$ & & & & & & $\begin{array}{l}+ \\
>\end{array}$ \\
\hline High Corp & - & $\begin{array}{l}- \\
* * *\end{array}$ & $\begin{array}{l}+ \\
* *\end{array}$ & $\begin{array}{l}- \\
* * *\end{array}$ & $-*$ & + & - & & - & & & & & & + \\
\hline Tax Wedge & + & + & + & - & $\begin{array}{l}- \\
* * *\end{array}$ & - & $\begin{array}{l}- \\
* * *\end{array}$ & & $\begin{array}{l}+ \\
*\end{array}$ & & & & & & $\begin{array}{l}- \\
* *\end{array}$ \\
\hline PMR & $\begin{array}{l}- \\
* * *\end{array}$ & + & $\begin{array}{l}- \\
* * *\end{array}$ & $\begin{array}{l}+ \\
* *\end{array}$ & $\begin{array}{l}- \\
* * *\end{array}$ & - & + & & $\begin{array}{l}+ \\
* *\end{array}$ & & & & & & \\
\hline ALMPs & $\begin{array}{l}+ \\
*\end{array}$ & + & - & $\begin{array}{l}+ \\
* *\end{array}$ & - & - & $\begin{array}{l}- \\
* *\end{array}$ & & & & & & & & \\
\hline $\begin{array}{l}\text { Unemploy. } \\
\text { benefit repl. rate }\end{array}$ & $\begin{array}{l}+ \\
* *\end{array}$ & $\begin{array}{l}+ \\
*\end{array}$ & $\begin{array}{l}+ \\
* *\end{array}$ & $\begin{array}{l}- \\
*\end{array}$ & & - & + & & & $\begin{array}{l}+ \\
>\end{array}$ & + & $\begin{array}{l}- \\
* *\end{array}$ & & & \\
\hline $\begin{array}{l}\text { Shocks } \\
\text { Cohort } \\
\text { Period }\end{array}$ & $\begin{array}{l}\text { Higher } \\
\text { cohort } \\
\text { Decrea }\end{array}$ & younger & $\begin{array}{l}* * \\
\text { Higher } \\
\text { cohort }\end{array}$ & younger & $\begin{array}{l}\text { Not } \mathrm{Si} \\
\text { Higher }\end{array}$ & younger & orts $* * *$ & & & & & & & & \\
\hline Adj-R2 & 0.978 & 372 & 0.929 & 320 & 0.942 & & & & & 320 & & & & & \\
\hline
\end{tabular}


Table 14. Summary results for wage immobility

\begin{tabular}{|c|c|c|c|c|c|c|c|c|c|c|c|c|c|c|c|}
\hline \multirow{3}{*}{$\begin{array}{l}\text { Earnings } \\
\text { Immobility }\end{array}$} & \multicolumn{2}{|c|}{ Model 1} & \multicolumn{2}{|c|}{ Model 2} & \multicolumn{11}{|c|}{ Model 3} \\
\hline & \multirow[b]{2}{*}{ Direct } & \multirow[b]{2}{*}{ Syst. X } & \multirow[b]{2}{*}{ Direct } & \multirow[b]{2}{*}{$\begin{array}{l}\text { Syst. } \\
\text { Shock } \\
\text { X }\end{array}$} & \multirow[b]{2}{*}{ Direct } & \multirow{2}{*}{$\begin{array}{l}\text { Syst. } \\
\text { Shock } \\
\text { X }\end{array}$} & \multicolumn{9}{|c|}{ Interactions between institutions } \\
\hline & & & & & & & $\begin{array}{l}\text { EPL } \\
\mathrm{X}\end{array}$ & $\begin{array}{l}\text { Rel. } \\
\text { EPL } \\
X\end{array}$ & $\begin{array}{l}\text { UD } \\
\mathrm{X}\end{array}$ & $\begin{array}{l}\text { Int. } \\
\text { Corp } \\
\mathrm{X}\end{array}$ & $\begin{array}{l}\text { High } \\
\text { Corp } \\
\text { X }\end{array}$ & $\begin{array}{l}\text { TW } \\
\mathrm{X}\end{array}$ & $\begin{array}{l}\text { PMR } \\
\mathrm{X}\end{array}$ & $\begin{array}{l}\text { ALMP } \\
\mathrm{X}\end{array}$ & $\begin{array}{l}\text { UB } \\
\mathrm{X}\end{array}$ \\
\hline EPL & $\begin{array}{l}+ \\
* *\end{array}$ & + & + & $\begin{array}{l}+ \\
* * *\end{array}$ & $\begin{array}{l}+ \\
* * *\end{array}$ & $\begin{array}{l}+ \\
* * *\end{array}$ & & & $\begin{array}{l}+ \\
* * *\end{array}$ & $\begin{array}{l}- \\
* * * \\
>\end{array}$ & $\begin{array}{l}- \\
* * *\end{array}$ & + & $\begin{array}{l}- \\
* * *\end{array}$ & - & + \\
\hline Relative EPL & $\begin{array}{l}+ \\
*\end{array}$ & - & $\begin{array}{l}+ \\
* * *\end{array}$ & - & $\begin{array}{l}- \\
* * *\end{array}$ & - & & & & & & & & & \\
\hline Union Density & $\begin{array}{l}- \\
* *\end{array}$ & $\begin{array}{l}- \\
* *\end{array}$ & - & $\begin{array}{l}+ \\
* * *\end{array}$ & $\begin{array}{l}- \\
* *\end{array}$ & $\begin{array}{l}+ \\
* * *\end{array}$ & $\begin{array}{l}+ \\
* * *\end{array}$ & & & & & $\begin{array}{l}+ \\
* *\end{array}$ & - & & \\
\hline Inter. Corp & - & $\begin{array}{l}- \\
* * * \\
<\end{array}$ & $\begin{array}{l}+ \\
<\end{array}$ & $\begin{array}{l}- \\
* * * \\
<\end{array}$ & $\begin{array}{l}- \\
* * * \\
<\end{array}$ & $\begin{array}{l}- \\
* * * \\
>\end{array}$ & $\begin{array}{l}- \\
* * * \\
>\end{array}$ & & & & & + & $\begin{array}{l}+ \\
* * \\
>\end{array}$ & & \\
\hline High Corp & $\begin{array}{l}+ \\
* *\end{array}$ & $\begin{array}{l}- \\
* * *\end{array}$ & + & $\begin{array}{l}- \\
* * *\end{array}$ & $\begin{array}{l}- \\
* * *\end{array}$ & $\begin{array}{l}- \\
* * *\end{array}$ & $\begin{array}{l}- \\
* * *\end{array}$ & & & & & - & $\begin{array}{l}+ \\
* *\end{array}$ & & \\
\hline Tax Wedge & + & - & - & $\begin{array}{l}- \\
* *\end{array}$ & + & $\begin{array}{l}- \\
* * *\end{array}$ & + & & $\begin{array}{l}+ \\
* *\end{array}$ & + & - & & & $\begin{array}{l}- \\
* *\end{array}$ & \\
\hline PMR & + & $\begin{array}{l}+ \\
* *\end{array}$ & + & $\begin{array}{l}+ \\
* *\end{array}$ & $\begin{array}{l}- \\
* *\end{array}$ & $\begin{array}{l}+ \\
* * *\end{array}$ & $\begin{array}{l}- \\
* * *\end{array}$ & & - & $\begin{array}{l}+ \\
* * \\
>\end{array}$ & $\begin{array}{l}+ \\
* *\end{array}$ & & & $\begin{array}{l}+ \\
* *\end{array}$ & $\begin{array}{l}- \\
* * *\end{array}$ \\
\hline ALMPs & $\begin{array}{l}+ \\
* *\end{array}$ & $\begin{array}{l}+ \\
* *\end{array}$ & - & $\begin{array}{l}+ \\
* *\end{array}$ & - & $\begin{array}{l}+ \\
* * *\end{array}$ & - & & & & & $\begin{array}{l}- \\
* *\end{array}$ & $\begin{array}{l}+ \\
* *\end{array}$ & & $\begin{array}{l}+ \\
* * *\end{array}$ \\
\hline $\begin{array}{l}\text { Unemploy. } \\
\text { benefit repl. rate }\end{array}$ & $\begin{array}{l}- \\
* *\end{array}$ & + & $\begin{array}{l}+ \\
* *\end{array}$ & $\begin{array}{l}- \\
*\end{array}$ & $\begin{array}{l}+ \\
* *\end{array}$ & $\begin{array}{l}- \\
* * *\end{array}$ & + & & & & & & $\begin{array}{l}- \\
* * *\end{array}$ & $\begin{array}{l}+ \\
* * *\end{array}$ & \\
\hline $\begin{array}{l}\text { Shocks } \\
\text { Cohort } \\
\text { Period }\end{array}$ & $\begin{array}{l}\text { Higher } \\
\text { cohort* } \\
\text { Decrea }\end{array}$ & $\begin{array}{l}\text { older the } \\
* * *\end{array}$ & $\begin{array}{l}5 \text { Sig. } \\
\text { Highe } \\
\text { cohort }\end{array}$ & older the & $\begin{array}{l}5 \text { Sig. } \\
\text { Higher }\end{array}$ & older the & hort*** & & & & & & & & \\
\hline Adj-R2 & 0.716 & 372 & 0.689 & 320 & 0.806 & & & & & 320 & & & & & \\
\hline
\end{tabular}




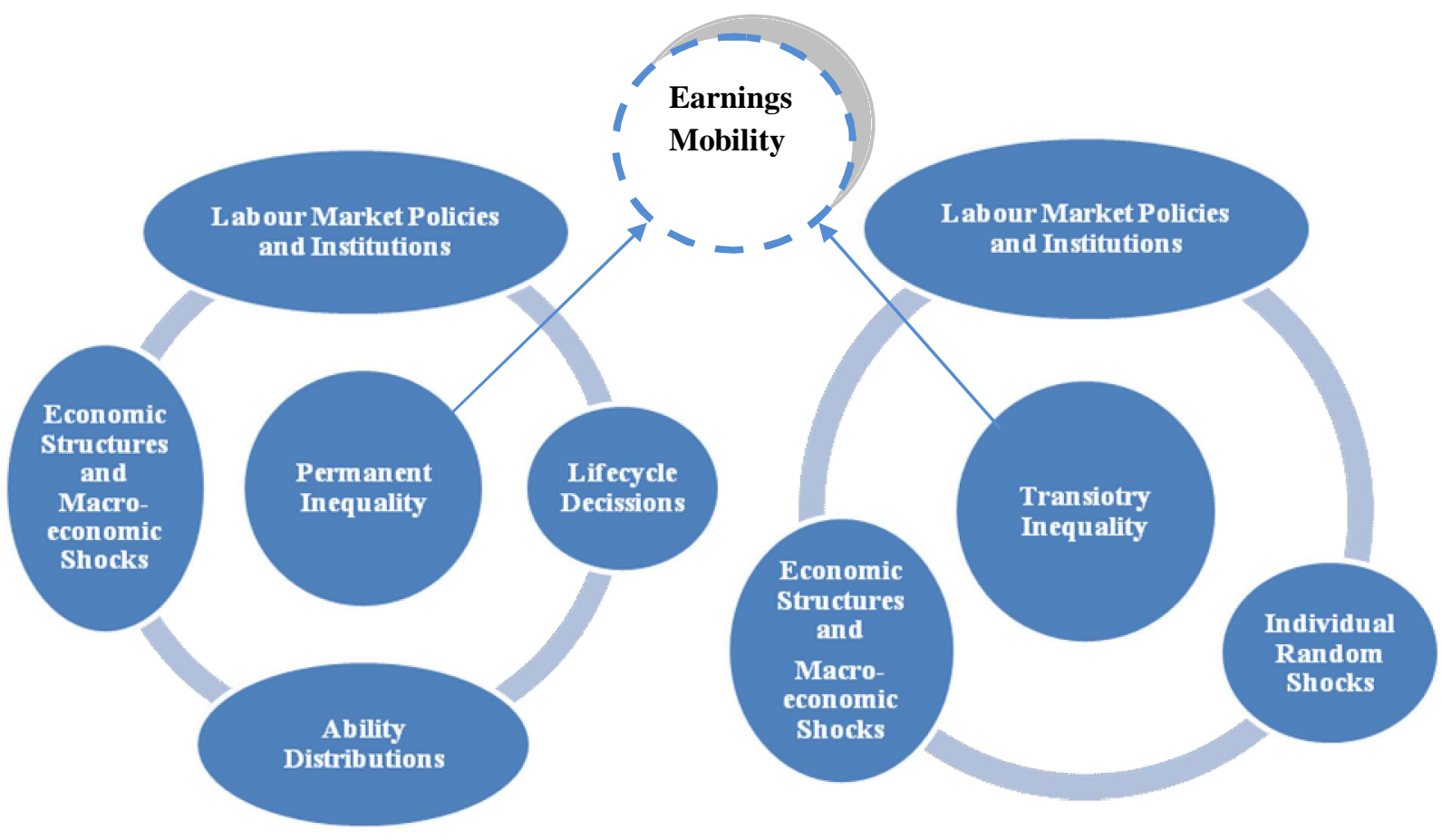

Figure 1. Determinants of Permanent and Transitory Inequality and Earnings Mobility 
Germany

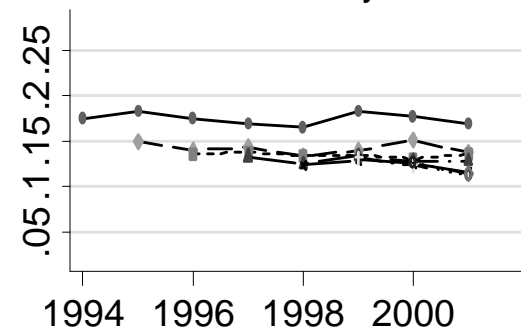

Belgium

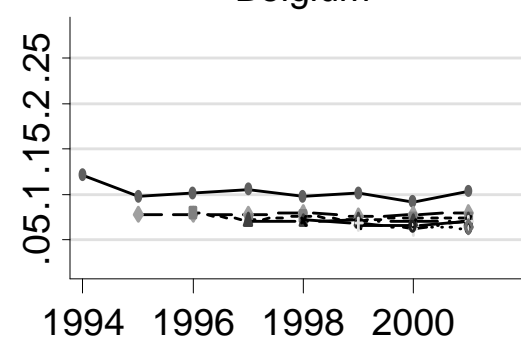

UK

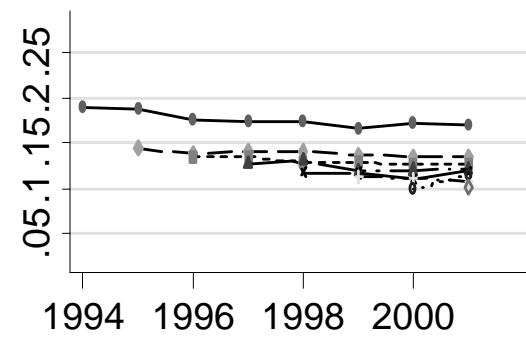

Greece

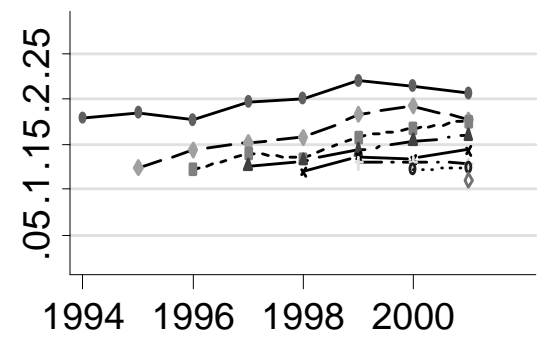

Austria

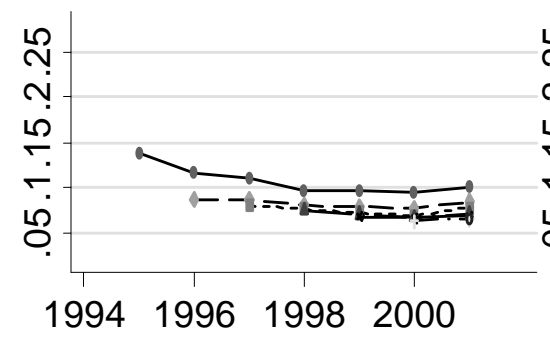

Denmark

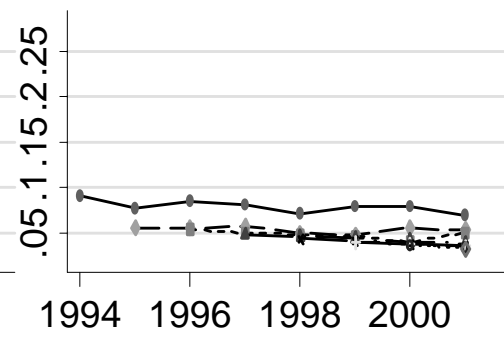

France

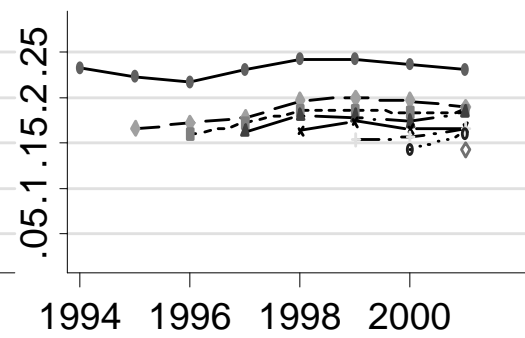

Ireland

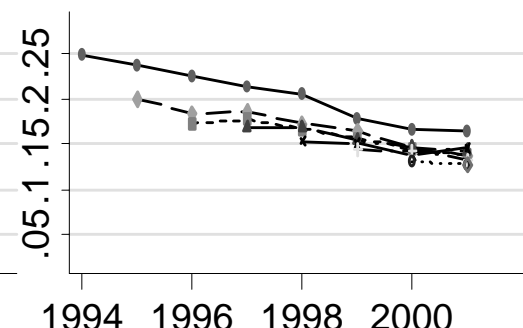

Spain

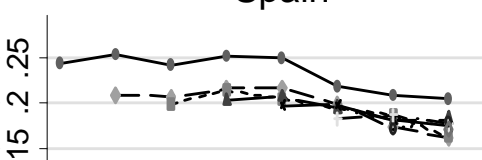

ஜ․

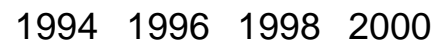

Netherlands

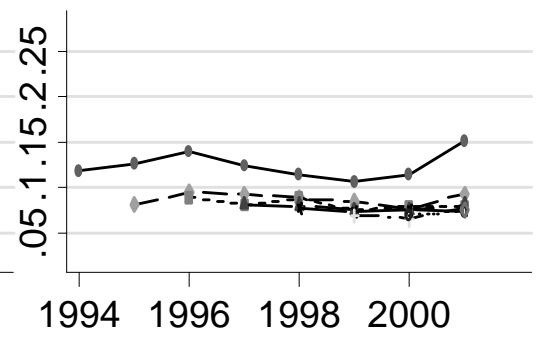

Luxembourg

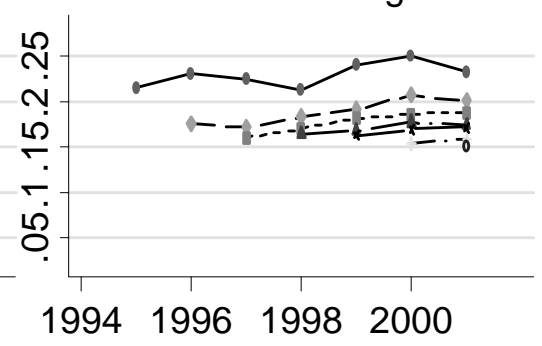

Italy
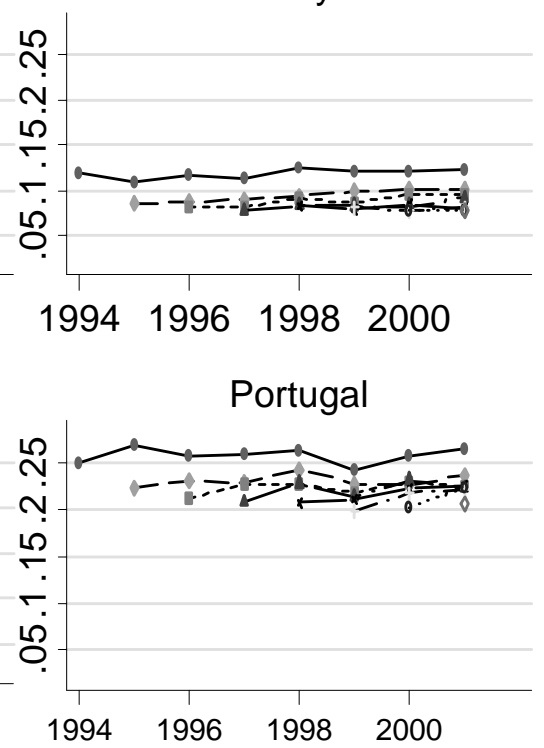

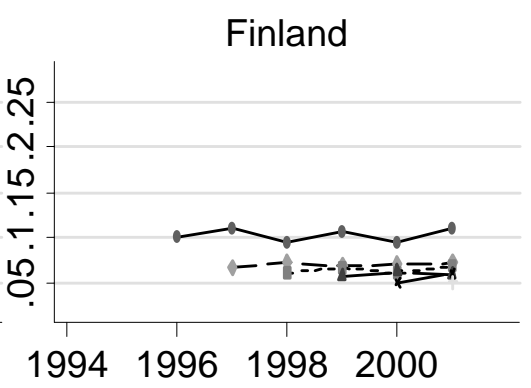

Figure 2. Overall Autocovariance Structure of Hourly Earnings: Years 1994-2001 

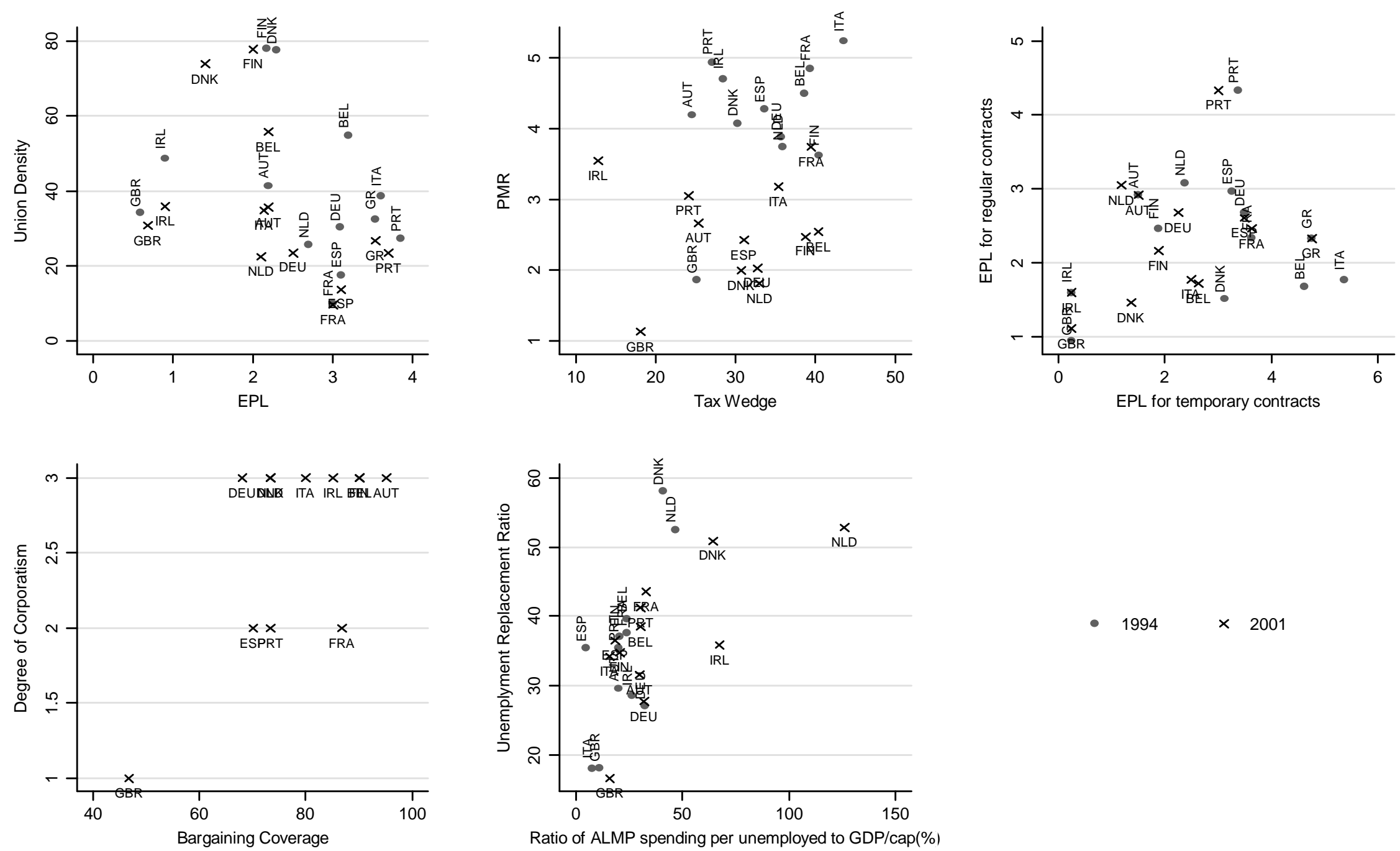

Figure 3. Labour Market Evolution: Union Density, EPL, PMR, Tax Wedge, , EPLT, EPLR, Degree of Corporatism, Bargaining Coverage 

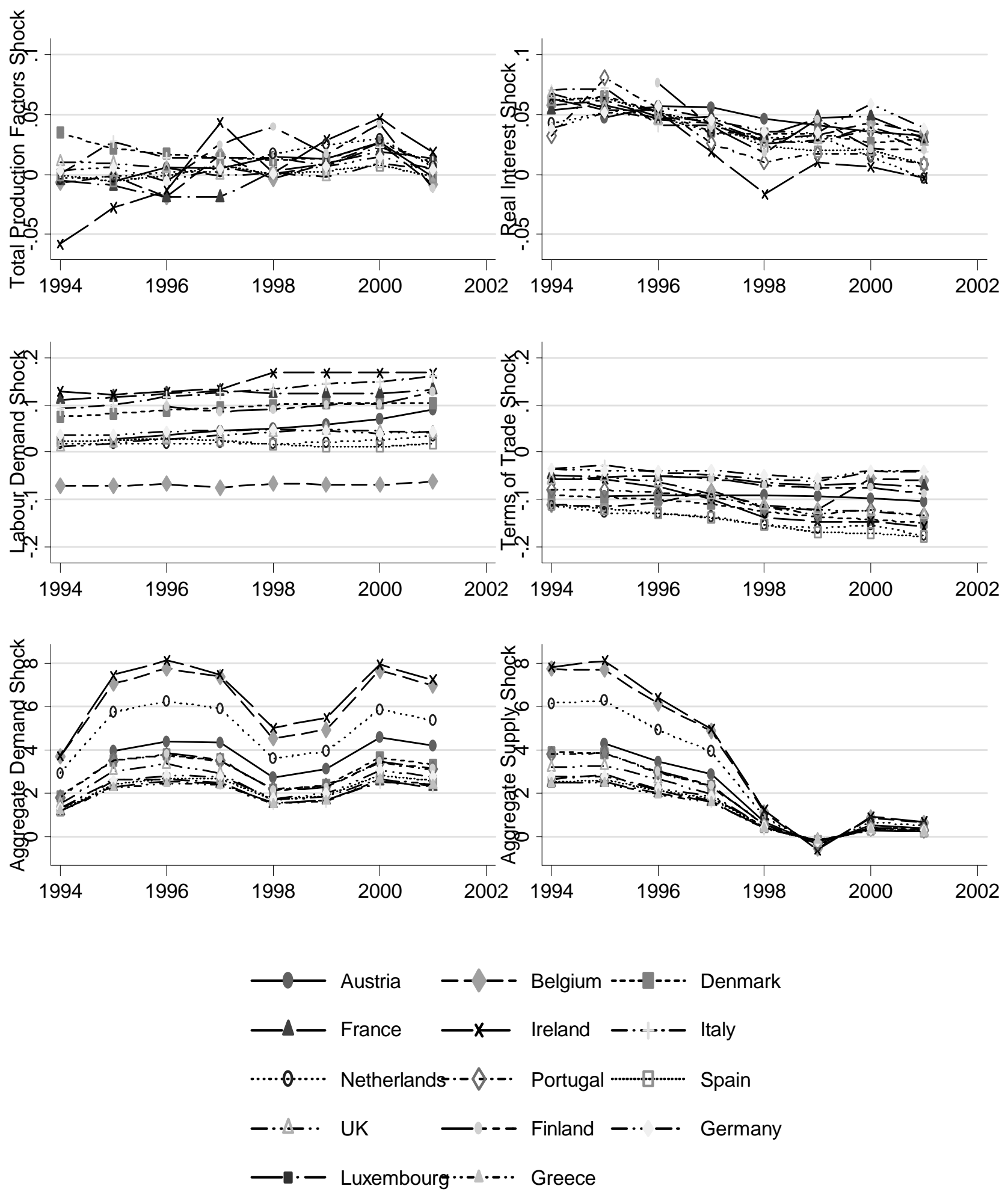

Figure 4. Evolution of macroeconomic shocks 

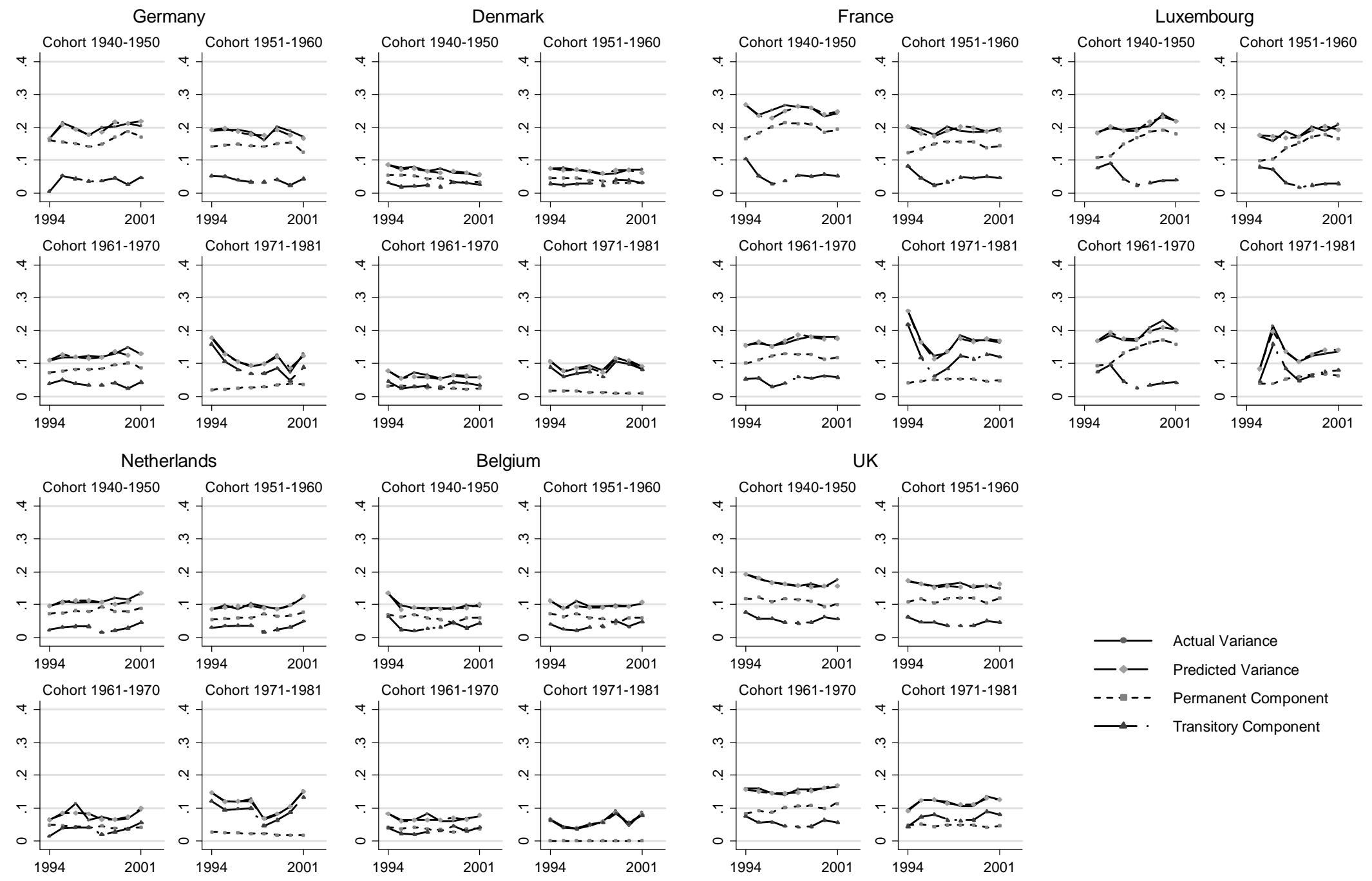

Figure 5. Actual and Predicted Variance of Earnings with Permanent and Transitory Predicted Components for Selected Cohorts: 19942001 
Ireland
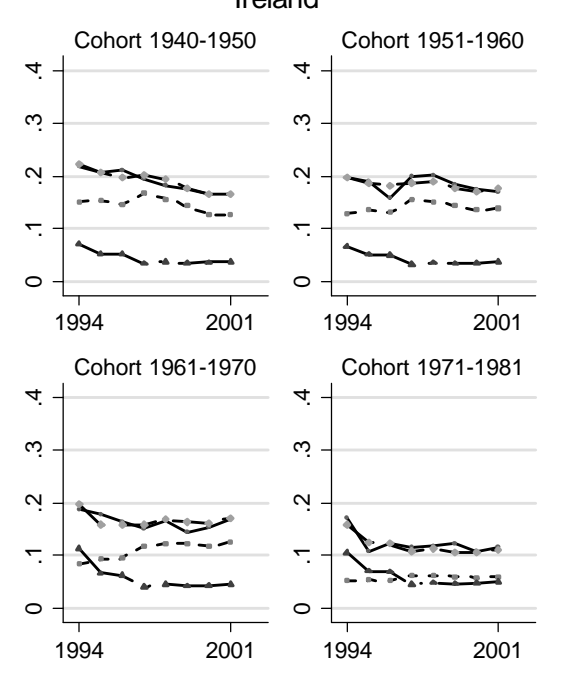

Greece
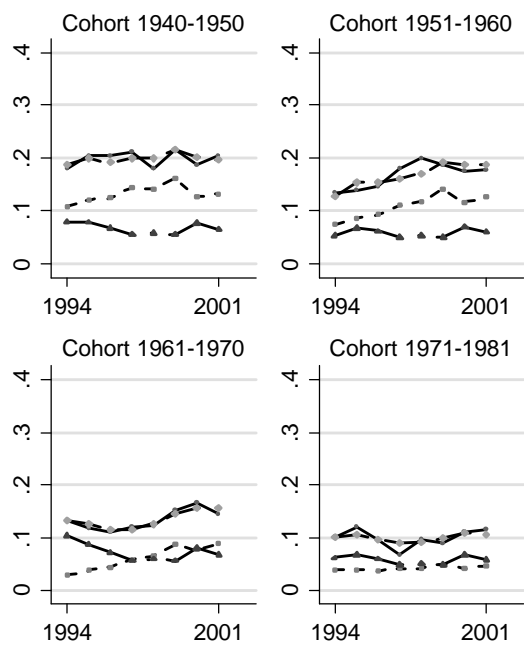

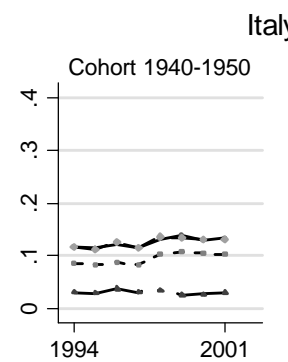

taly
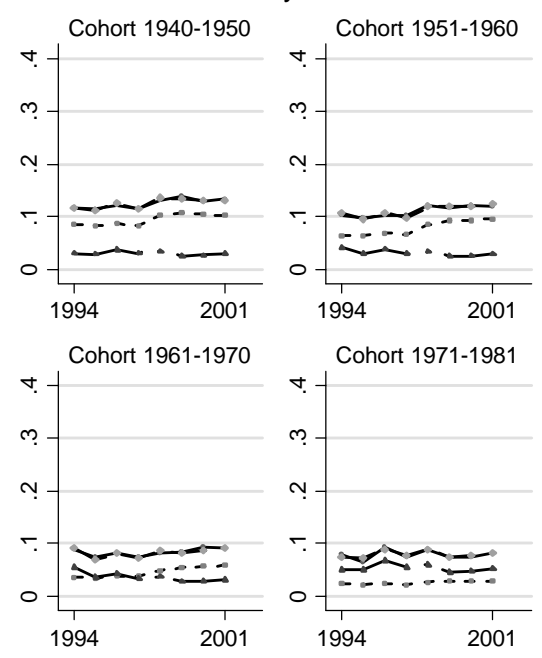

Spain
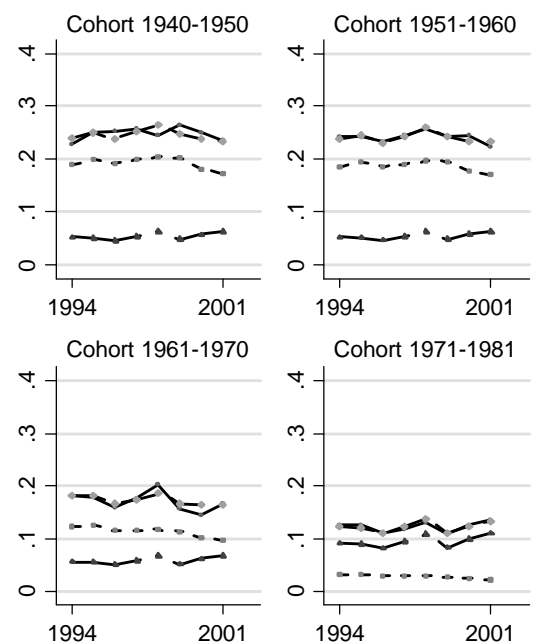

Portugal
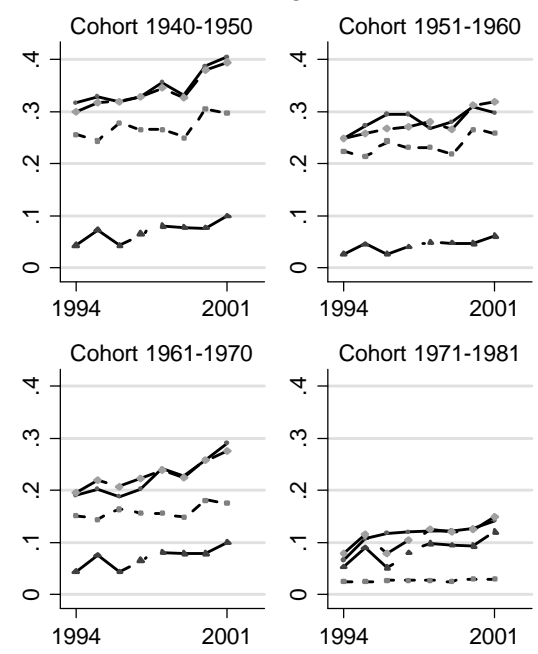

Finland
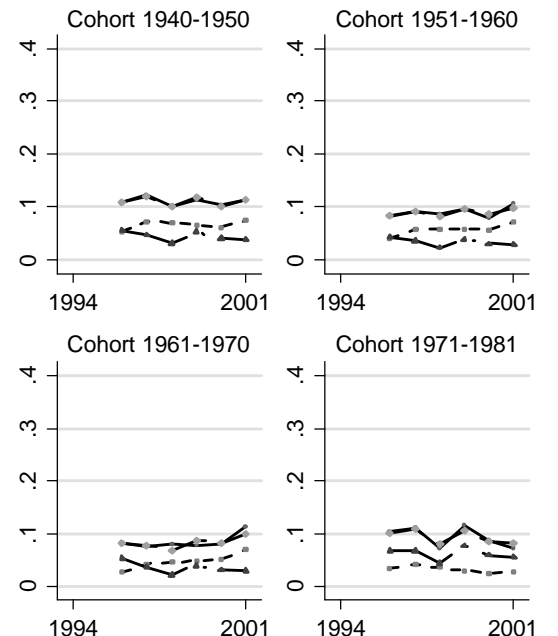

Cohort 1971-1981

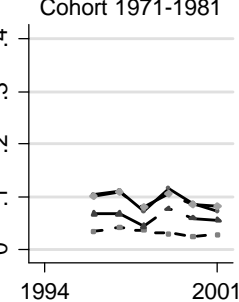

Austria
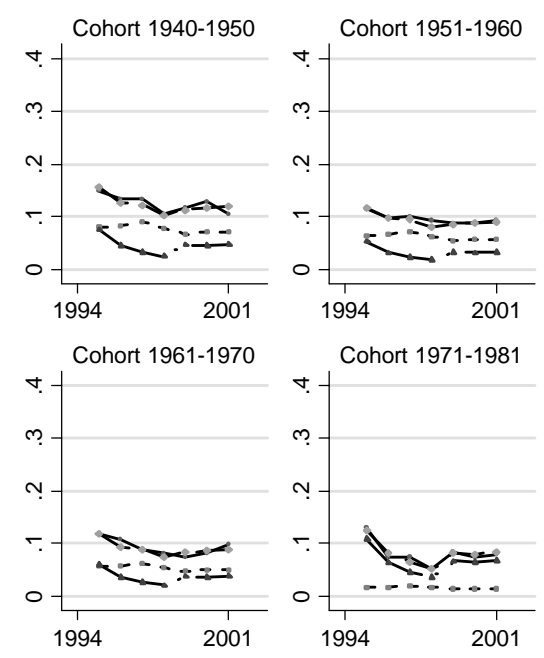

$\longrightarrow$ Actual Variance

- P Predicted Variance

- - - - Permanent Component

$\longrightarrow$ - Transitory Component

\section{Figure 5 (Continued)}



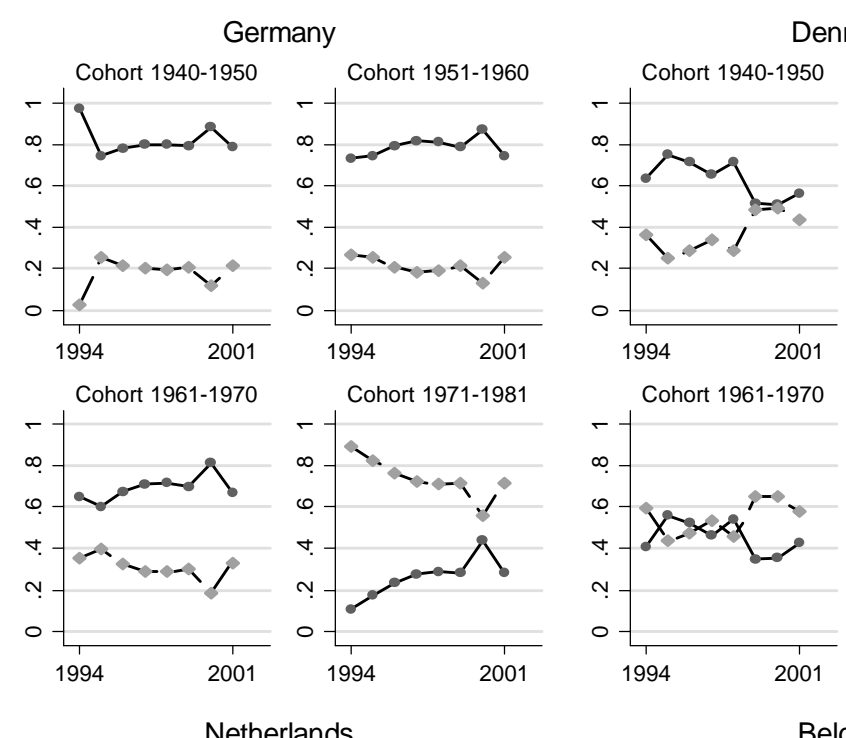

enmark

France
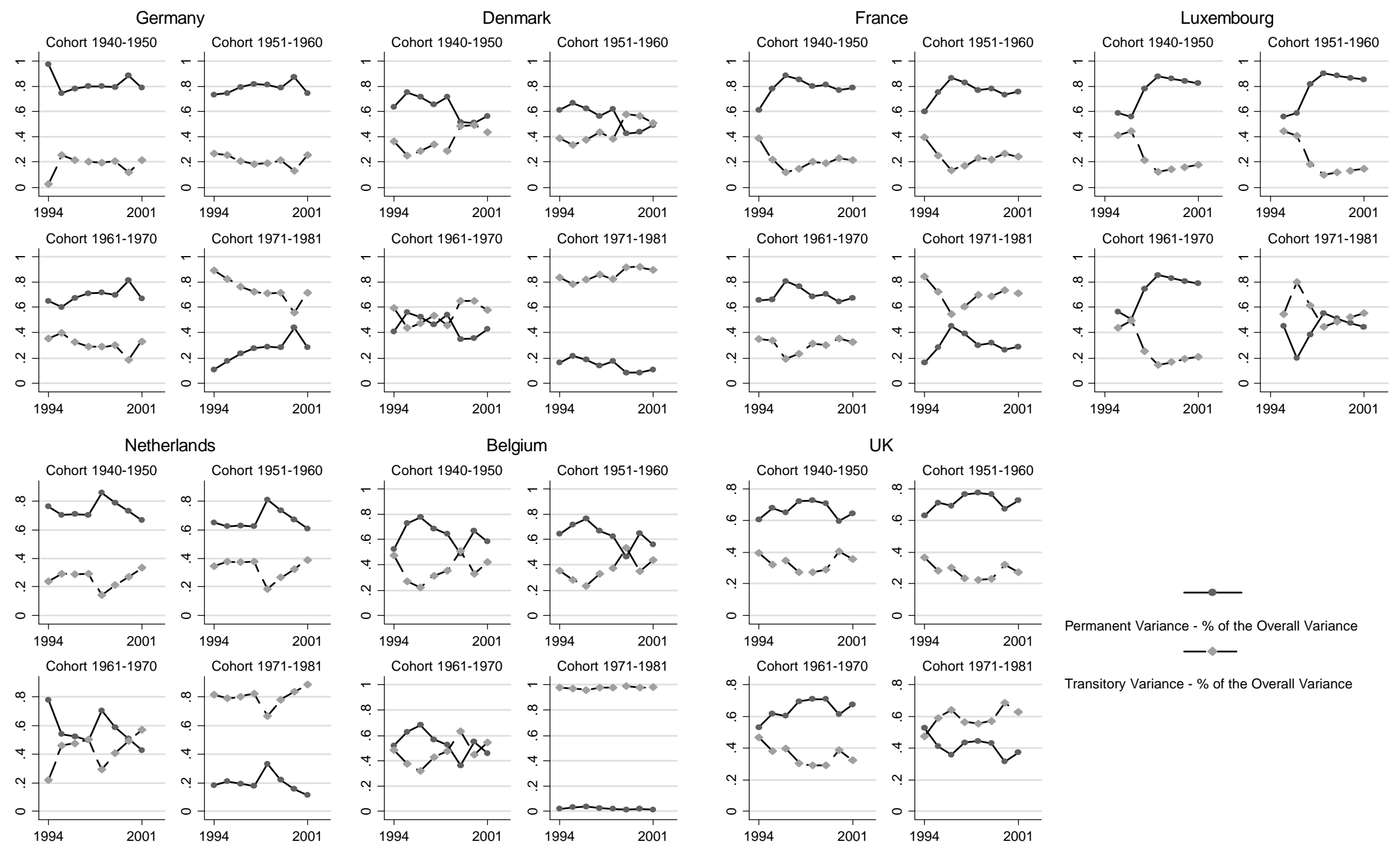

Permanent Variance - \% of the Overall Variance

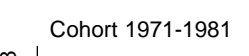

Transitory Variance - \% of the Overall Variance

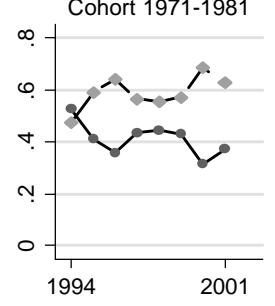

Figure 7. Predicted Permanent and Transitory Variance as \% of Predicted Overall Variance for Selected Cohorts: 1994-2001 

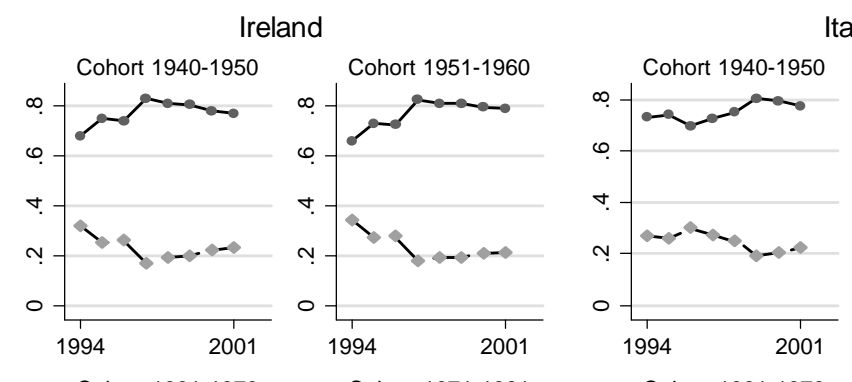

Italy

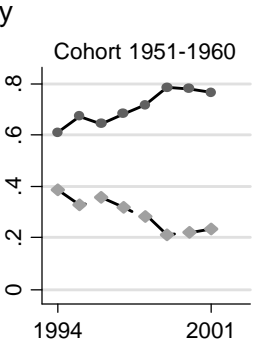

Portugal
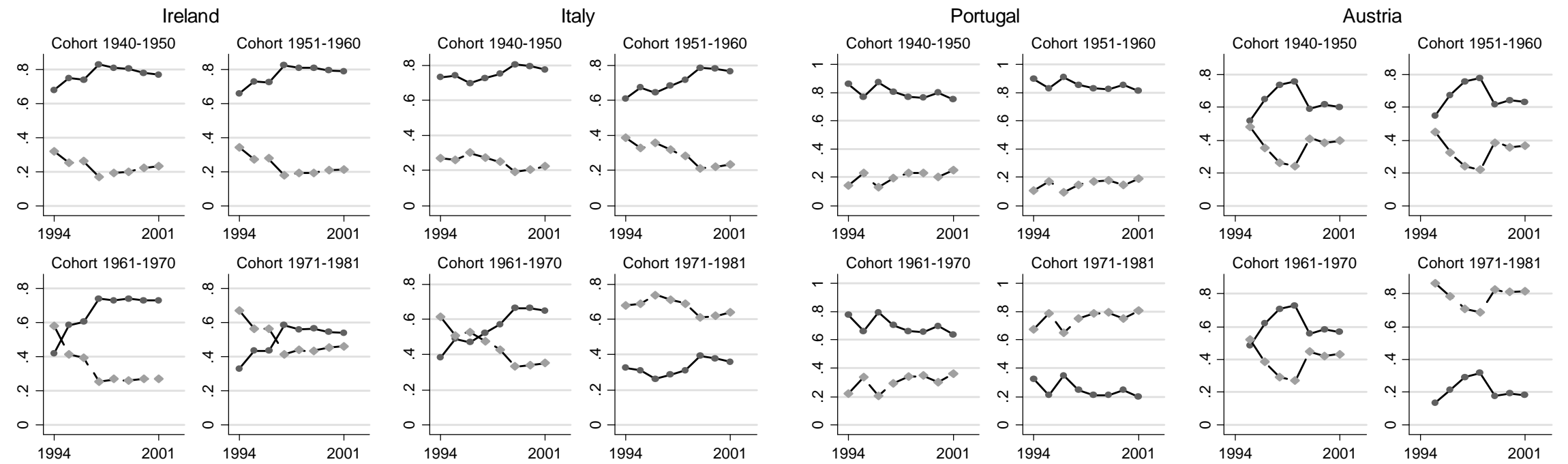

Greece
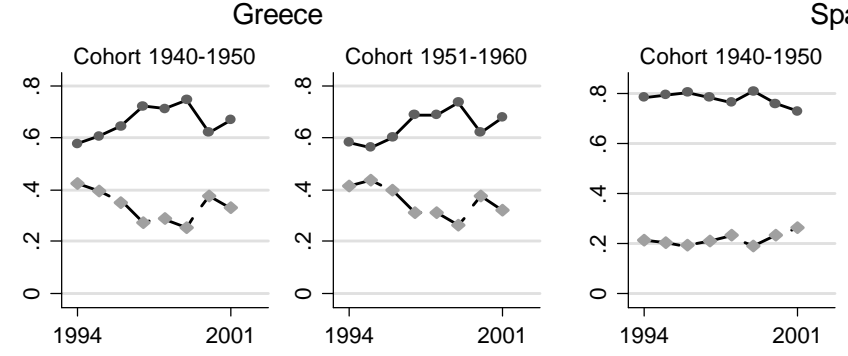

pain

Finland
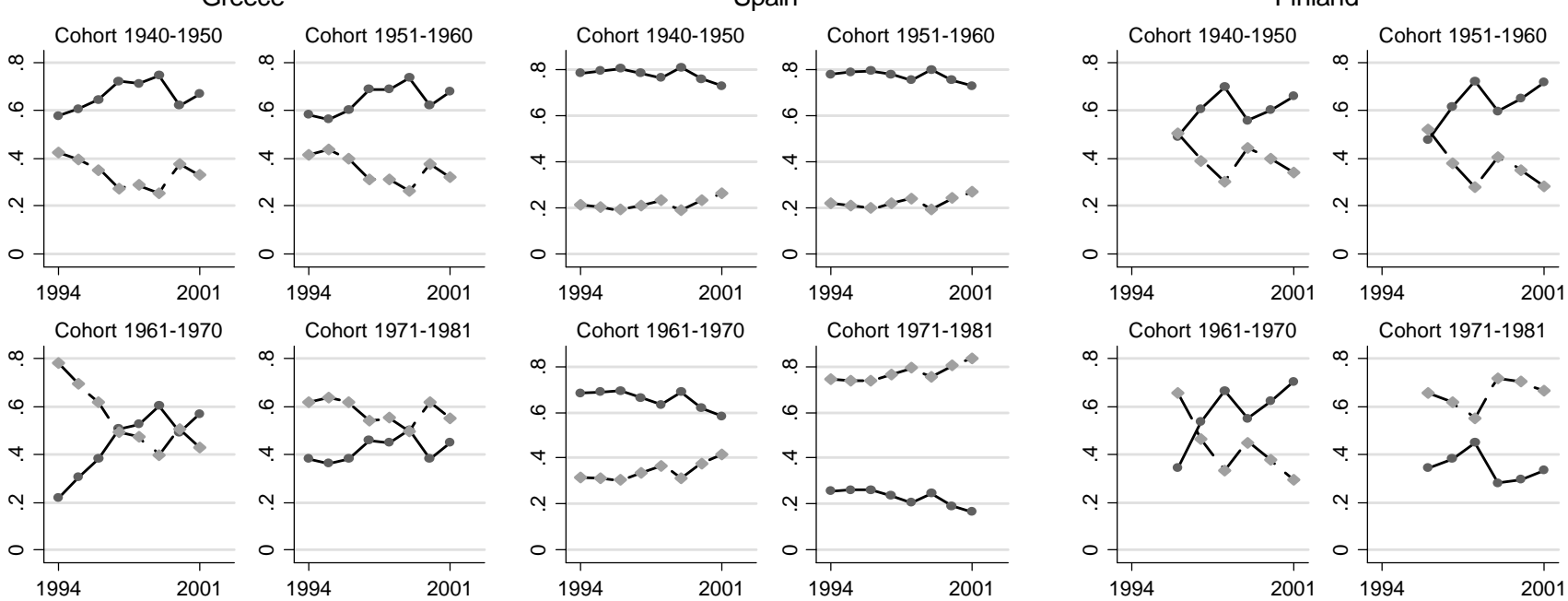

Permanent Variance - \% of the Overall Variance - -

Transitory Variance - \% of the Overall Variance

\section{Figure 7. (Continued)}



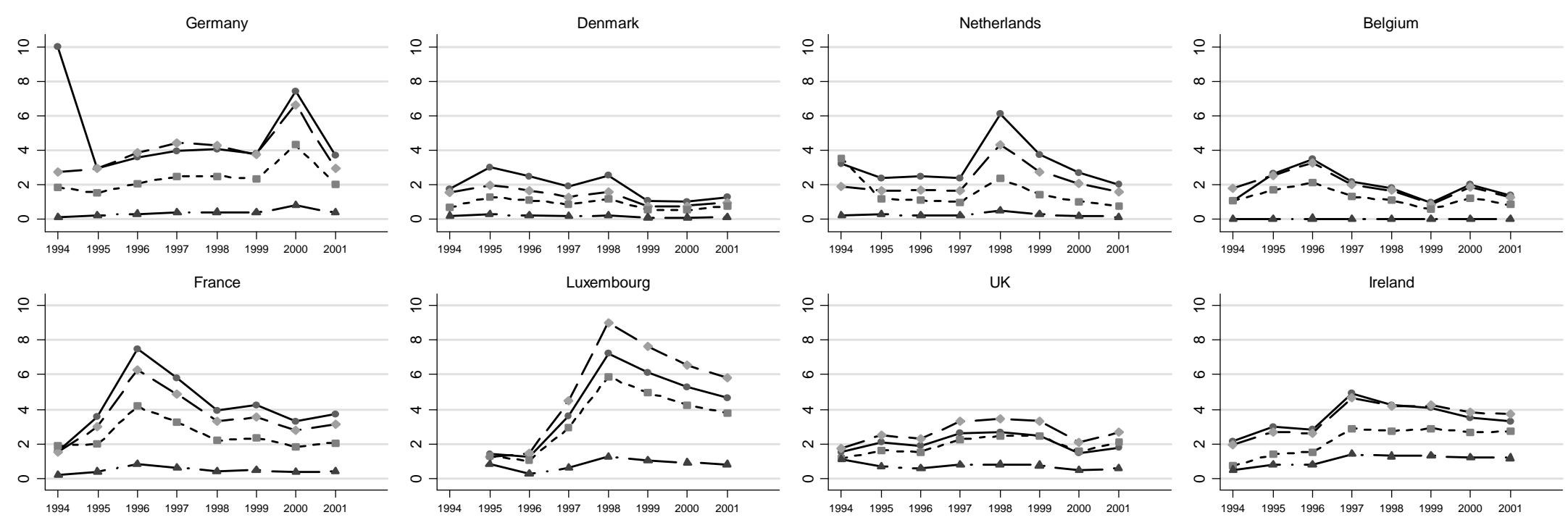

Italy
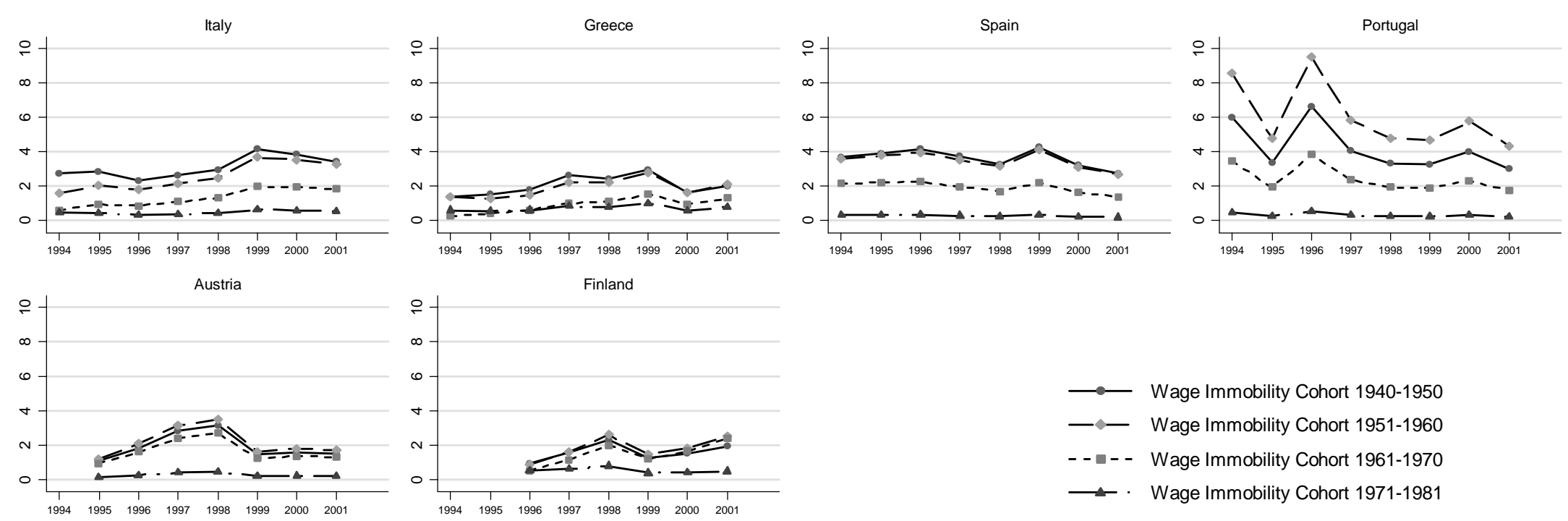

Figure 8. Ratio Between Permanent Variance and Transitory Variance Over Time For Selected Cohorts 
1st Wave
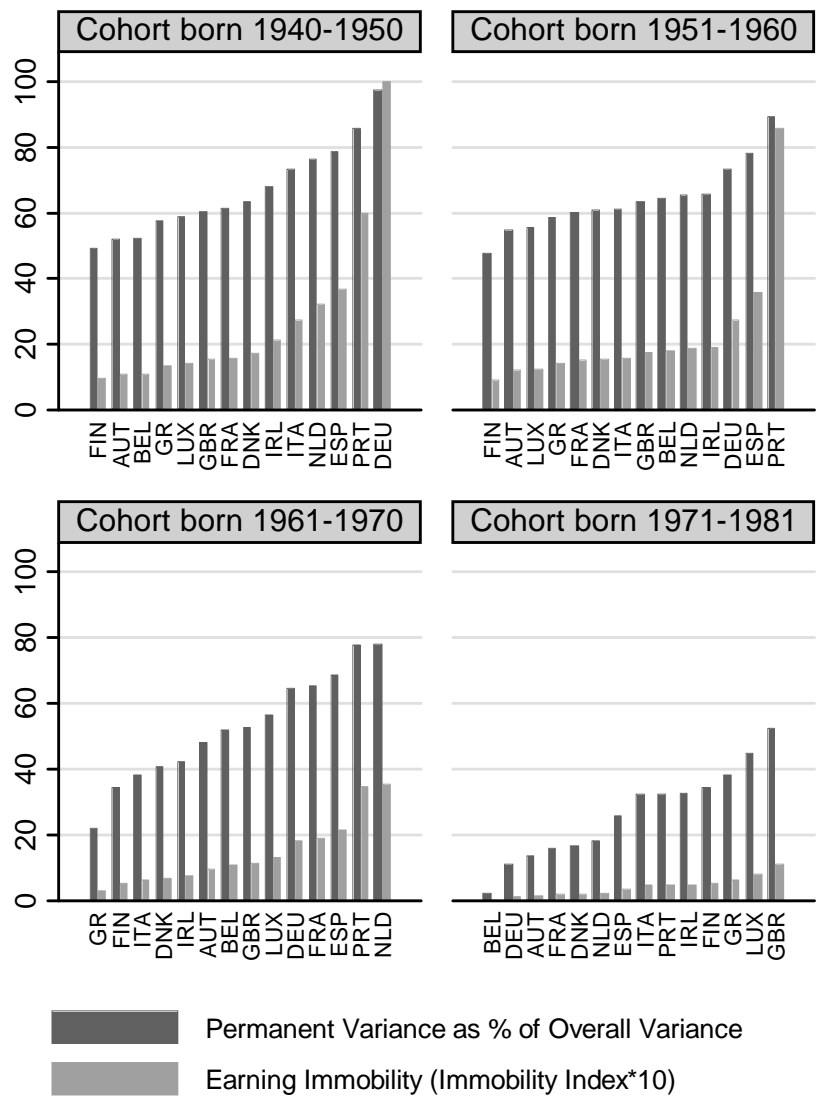

Graphs by Cohort
2001
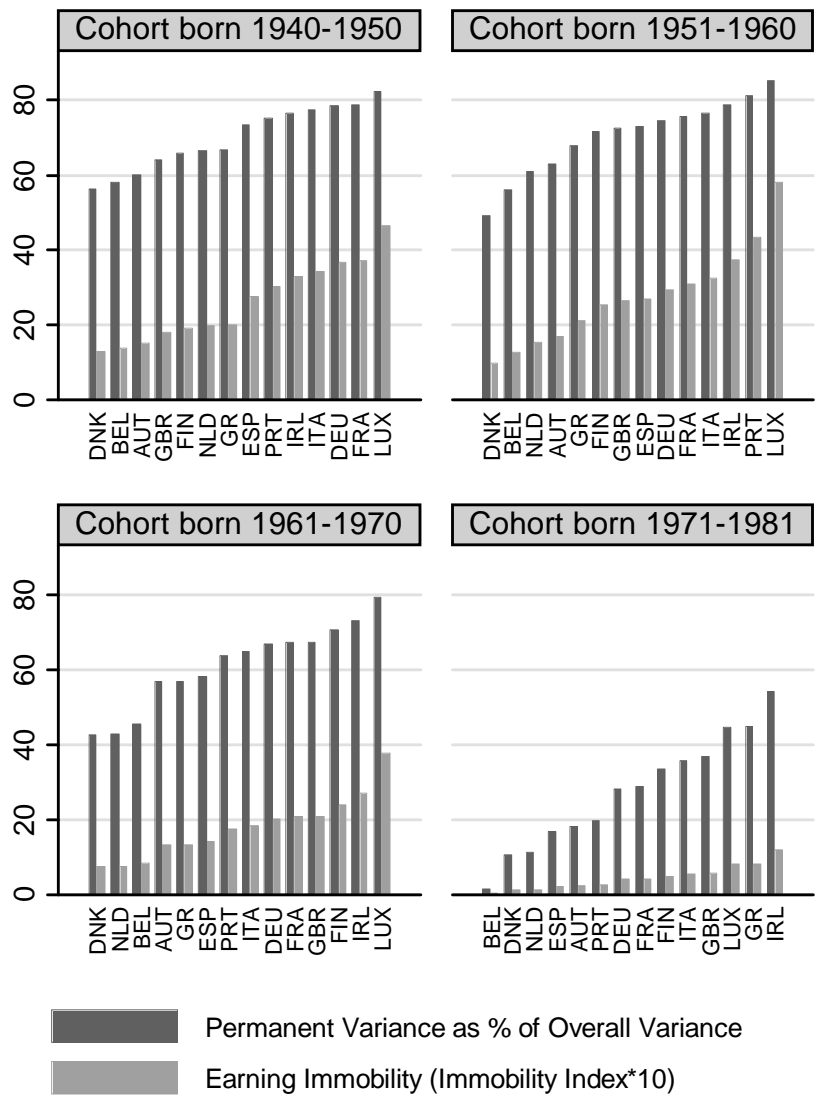

Graphs by Cohort

Figure 9. Permanent Inequality - \% of the Overall Inequality and Earnings Immobility for Selected Cohorts over Time 
Abowd, John M., and Card, David. 1989. On the covariance structure of earnings and hours changes. Econometrica, 57(2), 411-445.

Aghion, Philippe, and Williamson, Jeffrey G. 2001. Growth, Inequality and Globalization: Theory, History and Policy: Cambridge University Press.

Anderson, T. W., and Hsiao, Cheng. 1982. Formulation and estimation of dynamic models using panel data. Journal of Econometrics.

Atkinson, Anthony, B., Bourguignon, Francois, and Morrisson, C. (Eds.). (1992). Empirical studies of earnings mobility: Suisse : Harwood Academic Publishers.

Baker, Michael. 1997. Growth-rate heterogeneity and the covariance structure of life-cycle earnings. Journal of Labor Economics, 15(2), 338-375.

Baker, Michael, and Solon, Gary. 2003. Earnings dynamics and inequality among Canadian men, 1976-1992: evidence from longitudinal income tax records. Journal of Labor Economics, 21(2), 289-321.

Bassanini, A., and Duval, R. 2006a. The Determinants Of Unemployment Across OECD Countries: Reassessing The Role of Policies And Institutions. OECD Economics Studies, 42.

Bassanini, A., and Duval, R. 2006b. Employment Patterns In OECD Countries: Reassessing The Role Of Policies And Institutions. OECD Economics Department Working Papers, 486.

Bertola, G., Blau, F., and Kahn, L. 2002. Labor Market Institutions and Demographic Employment Patterns. NBER Working Paper 9043.

Blanchard, O. 1999. European unemployed: the role of shocks and institutions Paper presented at the Baffi Lecture.

Cappellari, Lorenzo. 2003. The dynamics and inequlaity of Italian men's earnings. The Journal of Human Resources, XXXIX.

Dew-Becker, Ian, and Gordon, Robert J. 2008. The Role of Labour Market Changes in the Slowdown of European Productivity Growth. CEPR Discussion Papers.

Dickens, Richard. 1999. Caught in a trap? Wage mobility in Great Britain: 1975-1994. Economica(67), 477-497.

Dickens, Richard. 2000. The evolution of individual male earnings in Great Britain: 1975-95. The Economic Journal, 110(460), 27-49.

EIROnline. http://www.eurofound.europa.eu/eiro/country index.htm.

Fortin, Nicole M., and Lemieux, Thomas. 1997. Institutional Changes and Rising Wage Inequality: Is there a Linkage? The Journal of Economic Perspectives, 11(2), 75-96.

Freeman, R., and Gibbons, R. 1995. Getting together and breaking appart: the decline in centralized bargaining. In Freeman andKatz (Eds.), Differences and changes in wage structures. Chicago: University of Chicago Press and NBER. 
Freeman, Richard B. 1975. Overinvestment in college training? Journal of human resources, 10, 287-311.

Freeman, Richard B. 1976. The overeducated American. San Diego: Academic Press.

Freeman, Richard B., and Katz, Lawrence F. 1994. Rising wage inequality: the United States vs. other advanced countries. In Freeman (Ed.), Working under different rules (pp. 29-62). New York: Russel Sage Foundation.

Friedman, M. 1962. Capitalism and Freedom. Chicago: University of Chicago Press.

Gottschalk, Peter, and Smeeding, Timothy M. 1997. Cross-national comparisons of earnings and income inequality. Journal of Economic Literature, 35(2), 633-687.

Hause, John C. 1977. The covariance structure of earnings and on-the-job training hypothesis. Annals of Economic and Social Measurement, 335-366.

Hause, John C. 1980. The fine structure of earnings and the on-the-job training hypothesis. Econometrica, 48(4), 1013-1029.

Kalwij, Adriaan, and Alessie, Rob. 2003. Permanent and transitory wage inequality of British men, 1975-2001: year, age and cohort effect. Journal of Applied Econometrics, 22, 1063 1093.

Katz, Lawrence F. 1994. Comments and discussion. Brookings Papers on Economic Activity(2), 255-261.

Katz, Lawrence F., and Autor, David H. 1999. Changes in the wage structure and earnings inequality. In Handbook of Labor Economics (Vol. 3): Elsevier Science B.V.

Layard, R., Nickell, S., and Jackman, R. 1991. Unemployment: macroeconomic performance and the labour market. Oxford: Oxford University Press.

Lillard, Lee A., and Weiss, Y. 1979. Components of variation in panel earnings data: American scientists 1960-70. Econometrica, 47(2), 437-454.

Lillard, Lee A., and Willis, R. 1978. Dynamic aspects of earnings mobility. Econometrica, 46(5), 985-1012.

MaCurdy, Thomas E. 1981. Time series models applied to panel data. Stanford University.

MaCurdy, Thomas E. 1982. The use of time series processes to model the error structure of earnings in a longitudinal data analysis. Journal of Econometrics, 18(1), 83-114.

Mincer, Jacob. 1957. A study of income distribution. Columbia University.

Mincer, Jacob. 1958. Investment in human capital and personal income distribution. Joournal of Political Economy, 66(4), 281-302.

Mincer, Jacob. 1962. On-the-job training: costs, returns and some implications. Journal of Political Economy, 70(5, Part 2), S50-S79.

Mincer, Jacob. 1974. Schooling, experience and earnings. New York: NY: NBER.

Moffitt, Robert, and Gottschalk, Peter. 1995. Trends in the covariance structure of earnings in the United States: 1969-1987. Paper presented at the Working Papers in Economics, No. 355. 
Moffitt, Robert, and Gottschalk, Peter. 1998. Trends in the variances of permanent and transitory earnings in the U.S. and their relation to earnings mobility. Boston College Working Papers, No. 444.

Moffitt, Robert, and Gottschalk, Peter. 2002. Trends in the transitory variance of earnings in the United States. The Economic Journal, 112(478), C68-C73.

Moffitt, Robert, and Gottschalk, Peter. 2008. Trends in the transitory variance of male earnings in the U.S., 1970-2004. Boston College Working Papers, No. 697.

OECD. 2004. Employment Outlook. Paris: OECD.

Ramos, Xavier. 2003. The covariance structure of earnings in Great Britain, 1991-1999. Economica, vol. 70(278), 353-374.

Rodrik, Dani. 1997. Has international integration gone too far? Washington, DC.

Sologon, Denisa M., and O'Donoghue, Cathal. 2009a. Earnings dynamics and inequality among men across 14 EU countries: evidence from ECHP. IZA Working Series, No. 4012(February).

Sologon, Denisa M., and O'Donoghue, Cathal. 2009b. Earnings dynamics and inequality in EU countries, 1994-2001. MGSOG Working Series(June).

Sologon, Denisa M., and O'Donoghue, Cathal. 2009c. Earnings dynamics and inequality in EU: 1994-2001. SOEPpapers on Multidisciplinary Panel Data Research, No. 184(April).

Topel, Robert H. 1997. Factor Proportions and Relative Wages: The Supply-Side Determinants of Wage Inequality. The Journal of Economic Perspectives, 11(2), 55-74.

Weizsacker, Robert K. von. 1993. A theory of earnings distributions. New York: Cambridge University Press. 


\section{Figures:}

Figure 1. Determinants of Permanent and Transitory Inequality and Earnings Mobility...........83

Figure 2. Overall Autocovariance Structure of Hourly Earnings: Years 1994-2001 .................84

Figure 3. Labour Market Evolution: Union Density, EPL, PMR, Tax Wedge, , EPLT, EPLR,

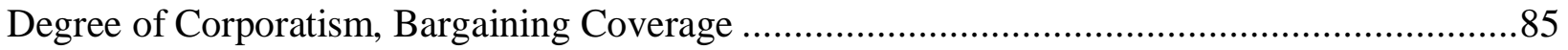

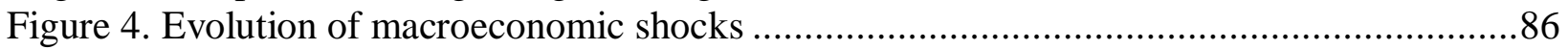

Figure 5. Actual and Predicted Variance of Earnings with Permanent and Transitory Predicted

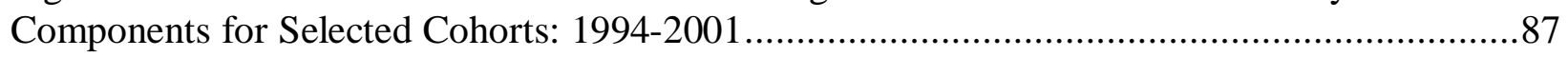

Figure 6. Actual and Predicted Variance of Earnings with Permanent and Transitory Predicted

Components for Selected Cohorts: 1994-2001 ............................................................

Figure 7. Predicted Permanent and Transitory Variance as \% of Predicted Overall Variance for

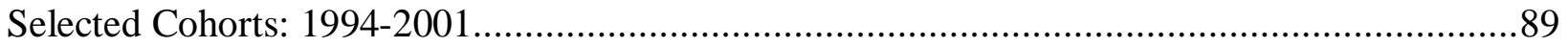

Figure 8. Ratio Between Permanent Variance and Transitory Variance Over Time For Selected

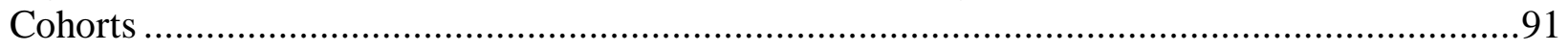

Figure 9. Permanent Inequality - \% of the Overall Inequality and Earnings Immobility for

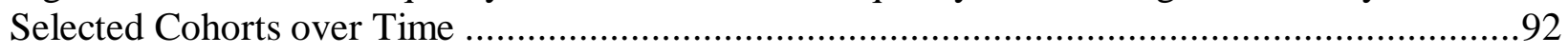

\section{Tables:}

Table 1. Mean hourly earnings and number of individuals with positive earnings ..................64

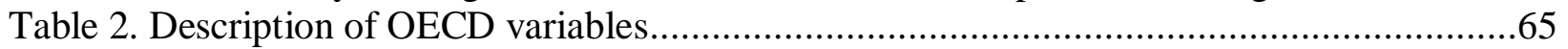

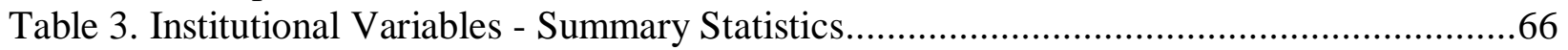
Table 4. Share of employees by educational level, by sector, by type of contract, by employment

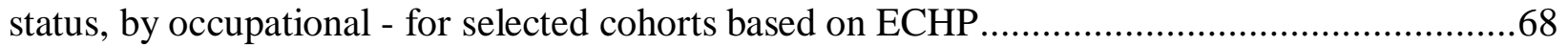

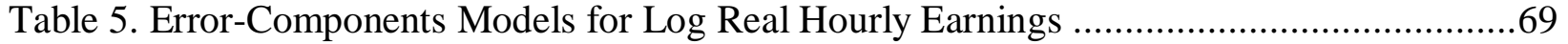
Table 6. Summary of the evolution of the actual inequality, permanent and transitory inequality, the permanent inequality as \% of predicted overall variance, and the immobility ratio, by cohorts:

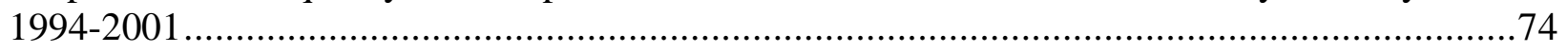

Table 7. Summary of the evolution of the average actual inequality, average permanent and

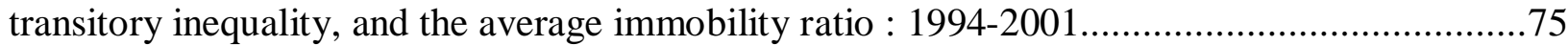
Table 8. Pair wise Correlations Between the Labour Market Outcomes, Labour Market

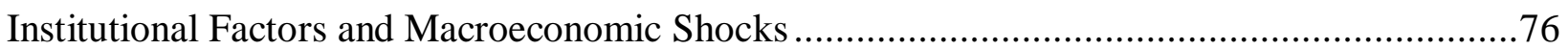
Table 9. Systemic Effects across Institutions ............................................................. 77 Table 10. Specific interactions between institutions and shocks... Error! Bookmark not defined. Table 11. Model with cross-interactions between institutions and between institutions and

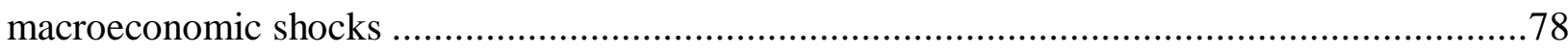




\section{Maastricht Graduate School of Governance}

\section{Working Paper Series}

List of publications

\begin{tabular}{|c|c|c|}
\hline 2010 & & \\
\hline No. & Author(s) & Title \\
\hline 001 & $\begin{array}{l}\text { Hercog, M. and A. } \\
\text { Wiesbrock }\end{array}$ & $\begin{array}{l}\text { The Legal Framework for Highly-Skilled Migration to the EU: EU and US } \\
\text { Labour Migration Policies Compared }\end{array}$ \\
\hline 002 & $\begin{array}{l}\text { Salanauskaite, L. } \\
\text { and G. Verbist }\end{array}$ & $\begin{array}{l}\text { The } 2004 \text { Law on Allowances to Children in Lithuania: What do } \\
\text { Microsimulations tell us about its Distributional Impacts? }\end{array}$ \\
\hline 003 & Salanauskaite, L. & $\begin{array}{l}\text { Microsimulation Modelling in Transition Countries: Review of Needs, } \\
\text { Obstacles and Achievements }\end{array}$ \\
\hline 2009 & & \\
\hline No. & Author(s) & Title \\
\hline 001 & $\begin{array}{l}\text { Roelen, K., } \\
\text { Gassmann, F. and } \\
\text { C. de Neubourg }\end{array}$ & $\begin{array}{l}\text { Child Poverty in Vietnam - providing insights using a country-specific and } \\
\text { multidimensional model }\end{array}$ \\
\hline 002 & $\begin{array}{l}\text { Siegel, M. and } \\
\text { Lücke, M. }\end{array}$ & $\begin{array}{l}\text { What Determines the Choice of Transfer Channel for Migrant } \\
\text { Remittances? The Case of Moldova }\end{array}$ \\
\hline 003 & $\begin{array}{l}\text { Sologon, D. and } \\
\text { O’Donoghue, C. }\end{array}$ & Earnings Dynamics and Inequality in EU 1994 - 2001 \\
\hline 004 & $\begin{array}{l}\text { Sologon, D. and } \\
\text { O’Donoghue, C. }\end{array}$ & Policy, Institutional Factors and Earnings Mobility \\
\hline 005 & $\begin{array}{l}\text { Muñiz Castillo, } \\
\text { M.R. and D. } \\
\text { Gasper }\end{array}$ & $\begin{array}{l}\text { Looking for long-run development effectiveness: An autonomy-centered } \\
\text { framework for project evaluation }\end{array}$ \\
\hline 006 & $\begin{array}{l}\text { Muñiz Castillo, } \\
\text { M.R. and D. } \\
\text { Gasper }\end{array}$ & $\begin{array}{l}\text { Exploring human autonomy effectiveness: Project logic and its effects on } \\
\text { individual autonomy }\end{array}$ \\
\hline 007 & $\begin{array}{l}\text { Tirivayi, } \mathrm{N} \text { and } \mathrm{W} \text {. } \\
\text { Groot }\end{array}$ & $\begin{array}{l}\text { The Welfare Effects of Integrating HIV/AIDS Treatment with Cash or In } \\
\text { Kind Transfers }\end{array}$ \\
\hline 008 & $\begin{array}{l}\text { Tomini, S., Groot, } \\
\text { W. and Milena } \\
\text { Pavlova }\end{array}$ & $\begin{array}{l}\text { Paying Informally in the Albanian Health Care Sector: A Two-Tiered } \\
\text { Stochastic Frontier Bargaining Model }\end{array}$ \\
\hline
\end{tabular}




\begin{tabular}{|c|c|c|}
\hline 009 & $\begin{array}{l}\text { Wu, T., and Lex } \\
\text { Borghans }\end{array}$ & $\begin{array}{l}\text { Children Working and Attending School Simultaneously: Tradeoffs in a } \\
\text { Financial Crisis }\end{array}$ \\
\hline 010 & $\begin{array}{l}\text { Wu, T., Borghans, } \\
\text { L. and Arnaud } \\
\text { Dupuy }\end{array}$ & $\begin{array}{l}\text { No School Left Behind: Do Schools in Underdeveloped Areas Have } \\
\text { Adequate Electricity for Learning? }\end{array}$ \\
\hline 011 & $\begin{array}{l}\text { Muñiz Castillo, } \\
\text { M.R. }\end{array}$ & $\begin{array}{l}\text { Autonomy as Foundation for Human Development: A Conceptual Model } \\
\text { to Study Individual Autonomy }\end{array}$ \\
\hline 012 & Petrovic, $\mathrm{M}$. & $\begin{array}{l}\text { Social Assistance, activation policy, and social exclusion: Addressing } \\
\text { Causal Complexity }\end{array}$ \\
\hline 013 & $\begin{array}{l}\text { Tomini, F. and J. } \\
\text { Hagen-Zanker }\end{array}$ & $\begin{array}{l}\text { How has internal migration in Albania affected the receipt of transfers } \\
\text { from kinship members? }\end{array}$ \\
\hline 014 & $\begin{array}{l}\text { Tomini, S. and } \mathrm{H} \text {. } \\
\text { Maarse }\end{array}$ & $\begin{array}{l}\text { How do patient characteristics influence informal payments for inpatient } \\
\text { and outpatient health care in Albania }\end{array}$ \\
\hline 015 & $\begin{array}{l}\text { D. Sologon and C. } \\
\text { O’Donoghue }\end{array}$ & $\begin{array}{l}\text { Equalizing or disequalizing lifetime earnings differentials? Earnings } \\
\text { mobility in the EU:1994-2001 }\end{array}$ \\
\hline 016 & $\begin{array}{l}\text { Henning and } \\
\text { Dr. Gar Yein Ng }\end{array}$ & $\begin{array}{l}\text { Steering collaborative e-justice. An exploratory case study of } \\
\text { legitimisation processes in judicial videoconferencing in the Netherlands }\end{array}$ \\
\hline 017 & $\begin{array}{l}\text { D. M. Sologon } \\
\text { and C. } \\
\text { O'Donoghue }\end{array}$ & $\begin{array}{l}\text { Increased Opportunity to Move up the Economic Ladder? Earnings } \\
\text { Mobility in EU: 1994-2001 }\end{array}$ \\
\hline 018 & $\begin{array}{l}\text { D. M. Sologon } \\
\text { and C. } \\
\text { O'Donoghue }\end{array}$ & Lifetime Earnings Differentials? Earnings Mobility in the EU: 1994-2001 \\
\hline 019 & D.M. Sologon & $\begin{array}{l}\text { Earnings Dynamics and Inequality among men in Luxembourg, 1988- } \\
\text { 2004: Evidence from Administrative Data }\end{array}$ \\
\hline 020 & $\begin{array}{l}\text { D. M. Sologon } \\
\text { and C. } \\
\text { O'Donoghue }\end{array}$ & Earnings Dynamics and Inequality in EU, 1994-2001 \\
\hline 021 & $\begin{array}{l}\text { D. M. Sologon } \\
\text { and C. } \\
\text { O'Donoghue }\end{array}$ & Policy, Institutional Factors and Earnings Mobility \\
\hline \multicolumn{3}{|l|}{2008} \\
\hline No. & Author(s) & Title \\
\hline 001 & $\begin{array}{l}\text { Roelen, K. and } \\
\text { Gassmann, F. }\end{array}$ & Measuring Child Poverty and Well-Being: a literature review \\
\hline
\end{tabular}




\begin{tabular}{|c|c|c|}
\hline 002 & Hagen-Zanker, J. & Why do people migrate? A review of the theoretical literature \\
\hline 003 & $\begin{array}{l}\text { Arndt, C. and C. } \\
\text { Omar }\end{array}$ & The Politics of Governance Ratings \\
\hline 004 & $\begin{array}{l}\text { Roelen, K., } \\
\text { Gassmann, F. and } \\
\text { C. de Neubourg }\end{array}$ & $\begin{array}{l}\text { A global measurement approach versus a country-specific measurement } \\
\text { approach. Do they draw the same picture of child poverty? The case of } \\
\text { Vietnam }\end{array}$ \\
\hline 005 & $\begin{array}{l}\text { Hagen-Zanker, J., } \\
\text { M. Siegel and C. } \\
\text { de Neubourg }\end{array}$ & Strings Attached: The impediments to Migration \\
\hline 006 & Bauchmüller, R. & $\begin{array}{l}\text { Evaluating causal effects of Early Childhood Care and Education } \\
\text { Investments: A discussion of the researcher's toolkit }\end{array}$ \\
\hline 007 & $\begin{array}{l}\text { Wu, T., } \\
\text { Borghans, L. and } \\
\text { A. Dupuy }\end{array}$ & $\begin{array}{l}\text { Aggregate Shocks and How Parents Protect the Human Capital } \\
\text { Accumulation Process: An Empirical Study of Indonesia }\end{array}$ \\
\hline 008 & $\begin{array}{l}\text { Hagen-Zanker, J. } \\
\text { and Azzarri, C. }\end{array}$ & Are internal migrants in Albania leaving for the better? \\
\hline 009 & $\begin{array}{l}\text { Rosaura Muñiz } \\
\text { Castillo, M. }\end{array}$ & $\begin{array}{l}\text { Una propuesta para analizar proyectos con ayuda internacional:De la } \\
\text { autonomía individual al desarrollo humano }\end{array}$ \\
\hline 010 & $\mathrm{Wu}, \mathrm{T}$. & Circular Migration and Social Protection in Indonesia \\
\hline \multicolumn{3}{|c|}{2007} \\
\hline No. & Author(s) & Title \\
\hline 001 & $\begin{array}{l}\text { Notten, G. and C. } \\
\text { de Neubourg }\end{array}$ & Relative or absolute poverty in the US and EU? The battle of the rates \\
\hline 002 & $\begin{array}{l}\text { Hodges, A. A. } \\
\text { Dufay, K. } \\
\text { Dashdorj, K.Y. } \\
\text { Jong, T. Mungun } \\
\text { and U. } \\
\text { Budragchaa }\end{array}$ & $\begin{array}{l}\text { Child benefits and poverty reduction: Evidence from Mongolia's Child } \\
\text { Money Programme }\end{array}$ \\
\hline 003 & $\begin{array}{l}\text { Hagen-Zanker, J. } \\
\text { and Siegel, M. }\end{array}$ & The determinants of remittances: A review of the literature \\
\hline 004 & Notten, G. & Managing risks: What Russian households do to smooth consumption \\
\hline 005 & $\begin{array}{l}\text { Notten, G. and C. } \\
\text { de Neubourg }\end{array}$ & $\begin{array}{l}\text { Poverty in Europe and the USA: Exchanging official measurement } \\
\text { methods }\end{array}$ \\
\hline
\end{tabular}




\begin{tabular}{|c|c|c|}
\hline 006 & $\begin{array}{l}\text { Notten, G and C. } \\
\text { de Neubourg }\end{array}$ & $\begin{array}{l}\text { The policy relevance of absolute and relative poverty headcounts: Whats in } \\
\text { a number? }\end{array}$ \\
\hline 007 & $\begin{array}{l}\text { Hagen-Zanker, J. } \\
\text { and M. Siegel }\end{array}$ & A critical discussion of the motivation to remit in Albania and Moldova \\
\hline 008 & $\mathrm{Wu}$, Treena & $\begin{array}{l}\text { Types of Households most vulnerable to physical and economic threats: } \\
\text { Case studies in Aceh after the Tsunami }\end{array}$ \\
\hline 009 & Siegel, M. & Immigrant Integration and Remittance Channel Choice \\
\hline 010 & Muñiz Castillo, M. & Autonomy and aid projects: Why do we care? \\
\hline \multicolumn{3}{|l|}{2006} \\
\hline No. & Author(s) & Title \\
\hline 001 & $\begin{array}{l}\text { Gassmann, F. and } \\
\text { G. Notten }\end{array}$ & $\begin{array}{l}\text { Size matters: Poverty reduction effects of means-tested and universal child } \\
\text { benefits in Russia }\end{array}$ \\
\hline 002 & $\begin{array}{l}\text { Hagen-Zanker, J. } \\
\text { and } \\
\text { M.R. Muñiz } \\
\text { Castillo }\end{array}$ & Exploring multi-dimensional wellbeing and remittances in El Salvador \\
\hline 003 & Augsburg, B. & $\begin{array}{l}\text { Econometric evaluation of the SEWA Bank in India: Applying matching } \\
\text { techniques based on the propensity score }\end{array}$ \\
\hline 004 & $\begin{array}{l}\text { Notten, G. and } \\
\text { D. de } \\
\text { Crombrugghe }\end{array}$ & Poverty and consumption smoothing in Russia \\
\hline \multicolumn{3}{|l|}{2005} \\
\hline No. & Author(s) & Title \\
\hline 001 & Gassmann, F. & $\begin{array}{l}\text { An Evaluation of the Welfare Impacts of Electricity Tariff Reforms And } \\
\text { Alternative Compensating Mechanisms In Tajikistan }\end{array}$ \\
\hline 002 & Gassmann, F. & $\begin{array}{l}\text { How to Improve Access to Social Protection for the Poor? } \\
\text { Lessons from the Social Assistance Reform in Latvia }\end{array}$ \\
\hline
\end{tabular}

